\title{
OLD NEW YORK Yesterday \& Today
}

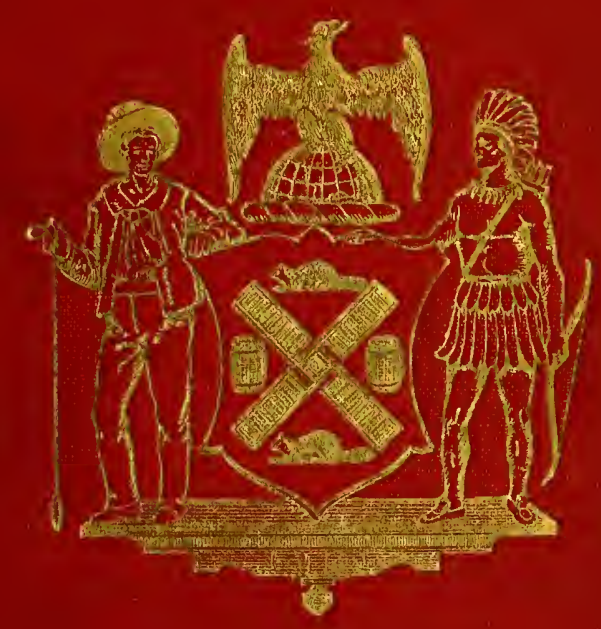

HERRY COLLINS BROWR 


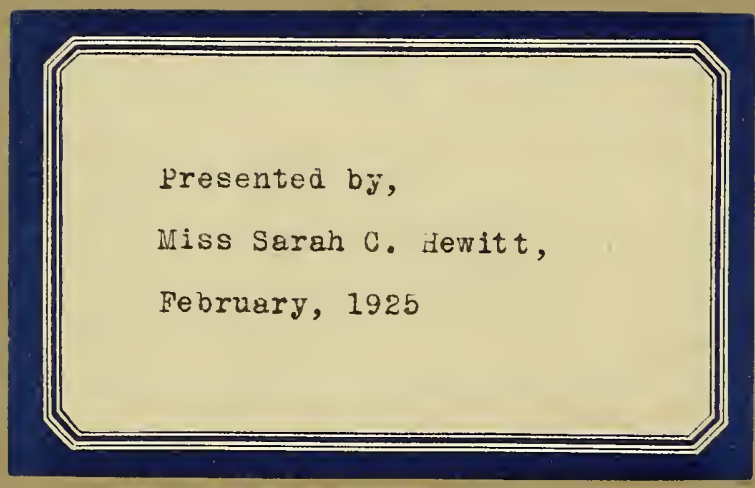








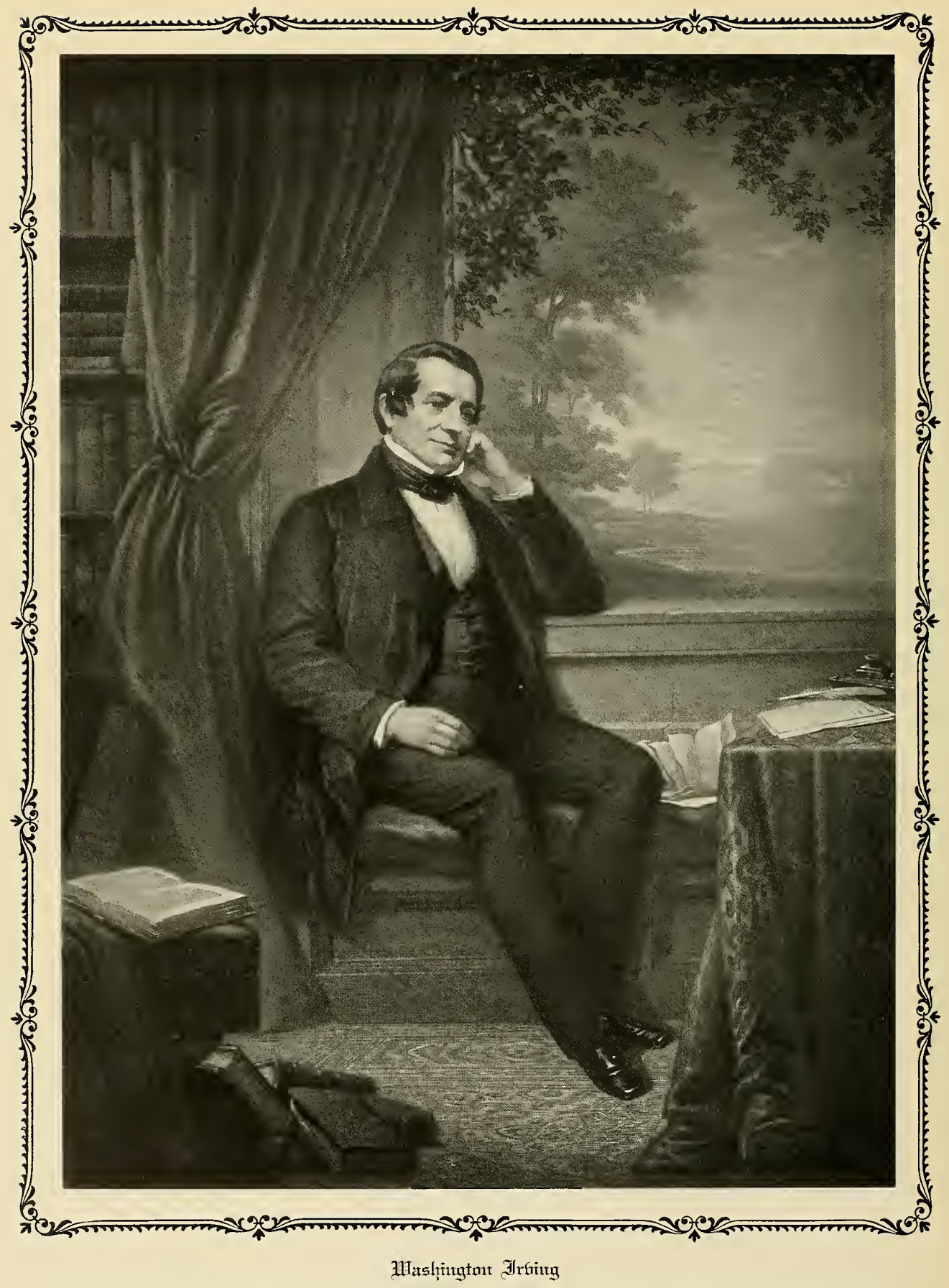

Born in William Street 1783 ; Died at "Sunnyside," Irvington-on-Hudson, 1859 . The first American author to secure foreign recognition for American Letters. His whimsical "Historv of New York," his most famous work, still remains one of our best sellers. 


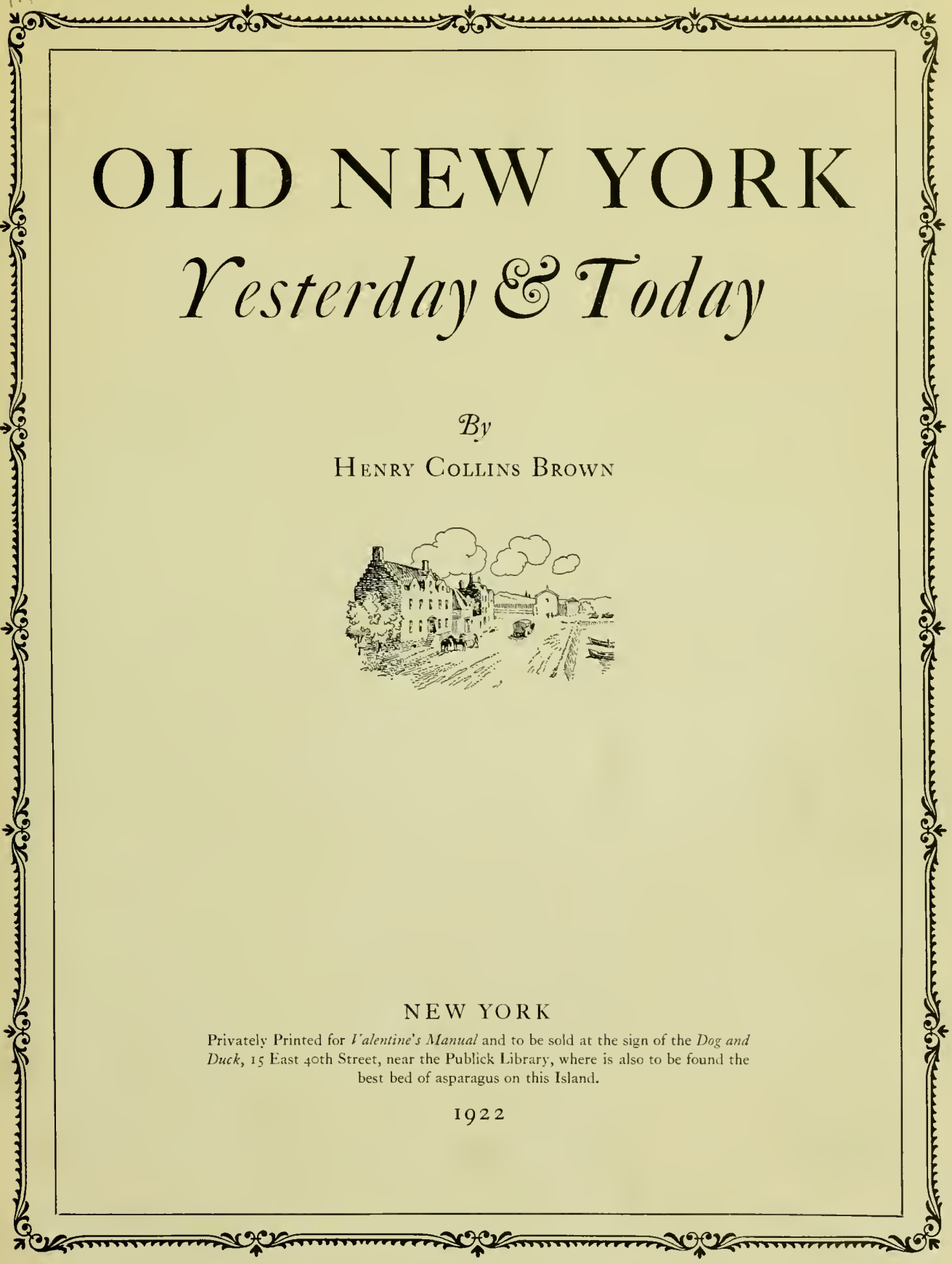




$$
\begin{aligned}
& F .87 \\
& 128.37 \\
& \text { B } 89 \times
\end{aligned}
$$




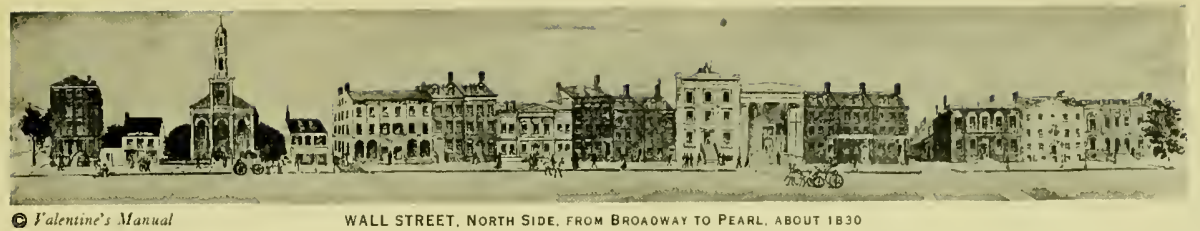

\section{FOREWORD}

7 He great City of New York will celebrate its three hundredth birthday early in 1926 . That is not very old as cities go. Yet New York has lived under three flags-Dutch, English and American. She is just twice as old as the Republic itself. The one hundred and fiftieth anniversary of the Founding of our Nation occurs in the same year, so these two events mark an important era in our progress, and deserve special recognition.

The year of the Peace with Great Britain $\left(\mathrm{I}_{7} 8_{3}\right)$ found our city in a deplorable condition. Two great fires had practically wiped out its principal buildings; their melancholy ruins still stood, gaunt and depressing. The population had dwindled to a beggarly ten thousand. Grass grew on her streets and her wharves, to which no ships had come in years, had fallen to decay. The machinery for local government had ceased to function and everywhere discouragement and dejection reigned supreme.

But with the appearance of Washington and his famous generals at the head of their victorious troops, marching down Broadway, a great change came over the spirit of New York. She was instantly imbued with new life. Her streets were once more thronged and she became for the moment the capital of the New Empire. Had New York so remained, it is safe to say that no Capital City in the world could have rivalled the beauty and impressiveness with which she would have constructed the Federal Seat of Government. A glance at the picture of lower Broadway shown elsewhere in these pages, distant but a few steps from the sparkling sheltered waters of the broad Atlantic, gives some idea of the possibilities that are apparent.

There were none of the conveniences in early days. When a fire broke out each citizen seized a leather bucket and repaired to the scene of action. Forming a human chain starting at the pump, and ending at the burning building, these valiant fire fighters attacked the conflagration with their little leather vessels and poured water on the flames till the fire was extinguished. Women in the neighboring houses prepared coffee and refreshments for the firemen. There was constant danger from this source, so the laws were stringent concerning fire buckets, and the ratio was one bucket for less than three fireplaces and two for more. Two "viewers of chimneys" and hearths were also employed and any person not having his bucket hanging in the hall where it could be instantly found was subject to a fine.

Our friend the Spanish Minister, the first diplomat by the way to be accredited to the young Republic, who resided at No. I Broadway, where a great steamship building now stands, had a fire in his house once and afterwards printed the following quaint little card in the papers, which gives a most fascinating glimpse of the simplicity of life as it was lived in those days:

"Don Diego de Gardoqui, the Spanish Minister, returns thanks to the citizens for their alacrity in extinguishing the fire that happened at his house. He observed many persons of the first distinction, actively employed, and although his doors were open to all, and the house filled with people, none of his effects were missing, everything carried out of the house having been restored."

The news savors also of a strange and distant past. The Weekly Post Boy chronicles the following (1802):

Melancholy Accident-Cow Kulles a Citizen in Beekman Street

"Yesterday afternoon as a genteel person was walking along Beekman Street, he was suddenly attacked by a cow. Notwithstanding that he used his best endeavors to beat her off he was so severely gored that he soon after expired. The cow was subsequently killed in William Street."

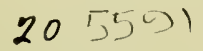


And here is a marriage notice from the Weekly Museum:

"On Monday evening, June 7th, I792, by the Rev. Mr. Beach, John Buchanan, Esq., to the amiable, adorable, incomparable, inflexible, invincible, and non parallel of her sex, Nancy Lucy Turner, both of this city."

And in some of these notices a few personal details were occasionally included that are not today thought of interest to those outside of the immediate family circle.

"Capt. Thompson Baxter was married to Miss Ann Whitman after a long and tedious courtship of 28 years which they both endured with uncommon Christian fortitude."

One more selection, showing the country-like aspect of our great city in those days:

"Strayed or stolen last night from an enclosure in Front Street a black bull calf. Any person who will give information at No. 261 Old Slip where it can be found, will receive the thanks of a poor blind woman."

But enough of Colonial days. The period over which we would most like to dwell, is one more within our own day - the last half century in New York. It seems to us the most alluring chapter in all its history. It marks the beginning of a new era. It is entirely within bounds to say that within that period more progress has been made in all those arts and sciences that tend to promote the happiness and comfort of mankind than in all the years that have elapsed since the Christian Era. Before that, there was not in all the world a telephone, a skyscraper, an electric light, an automobile, a bicycle, a trolley car, a "movie" or a radio.

Most of the houses were still of the two-story-red-brick type with dormer windows. All of them had stoops and basements. And in the summer time the neighborhood was rendered melodious by the young people singing the popular songs of the day- "Beautiful Isle of the Sea," "Sweet Genevieve," "In the Gloaming," etc. This program was frequently varied by the famous Harrigan \& Hart songs-"Paddy Duffy's Cart," "Maggie Murphy's Home," "The Market on Saturday Night," etc. It was all very bourgeoise but very delightful. Brownstone fronts began to make their appearance and a few years later the town was startled by the erection of the first apartment house. They were called French flats and owed their inception to the craze for everything French that prevailed in New York at the time.

Our interior furnishings appear to have been somewhat archaic judged by present standards. Piano legs and coal scuttles were adorned with huge sash ribbons of violent hue. Plush albums and Rogers statuary were conspicuous on tables with heavy cold marble tops. Mantels and pianos were draped with scarves of unimaginable floral designs topped off with silk fringe or embellished with heavy embroidery. Crayon portraits, in red plush frames, perched defiantly on scroll work easels, occupied a prominent place in the "best room." Whisk brooms were tied around with true lovers knots in pink ribbon; hand painted fire shovels, wax flowers in glass covers, "hassocks" with carpet coverings, hand painted placques in velvet frames, "What Nots" containing sea shells, baby's first shoes with a fresh coat of bronze, and sundry other family treasures -these and many other similar adornments proclaimed the home of refinement in the "Age of Innocence."

In view of our forthcoming Ter-centenary, it seemed to me that some of us might appreciate a little remembrancer of that rather imposing event. And I thought that if it took the form of the book you are now reading and contained a collection of pictures showing what we were and what we are, it might not be a bad idea. So with this initial number I have carried the plan into execution. Should this suggestion meet with any appreciable degree of public favor, the work will be expanded till I have in all half a dozen of these "Birthday Books." To a very great extent the History of New York can be fairly well told in pictures. And this is what I would like to do.

Henry Collins Brown. 


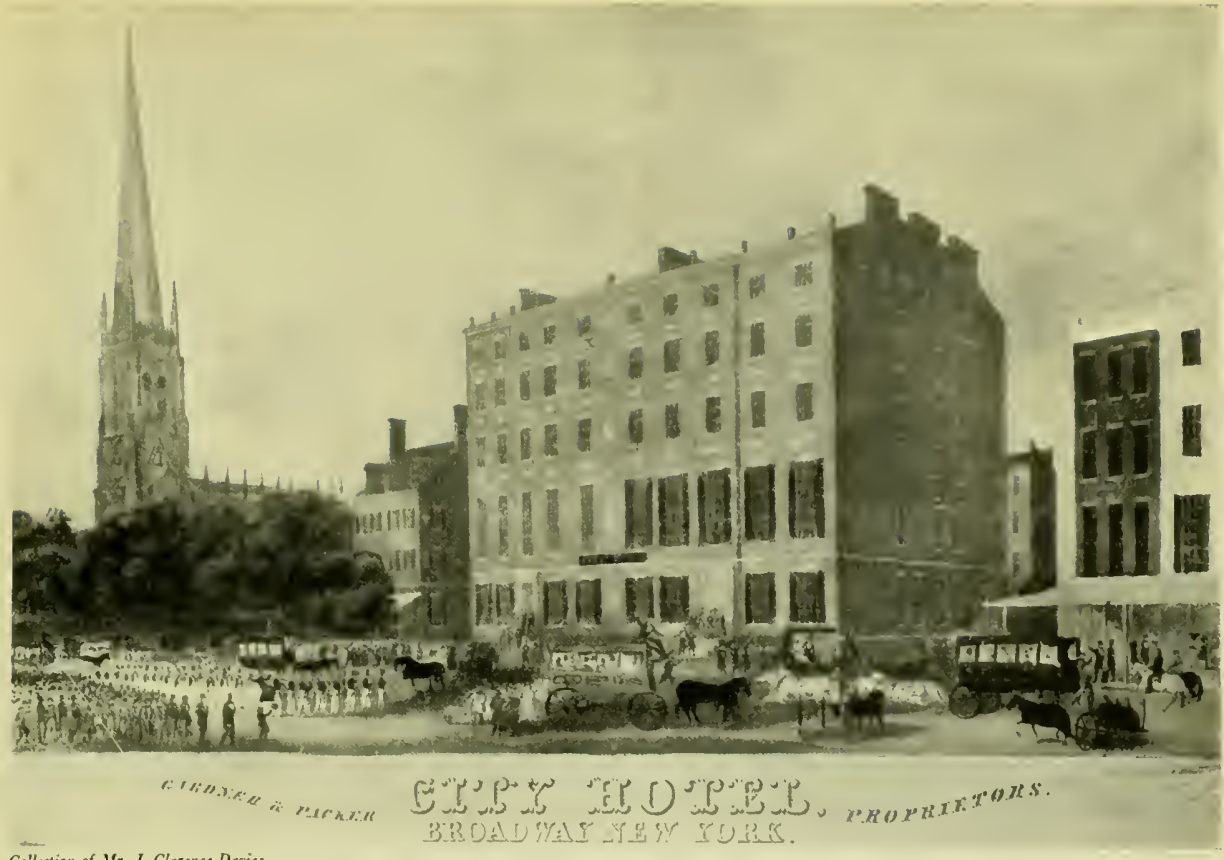

הirfu Zlark's Ifirst Flotel, ahourt 1789

On the site of the residence of Mr. Peter Delancey on Broadway, above Trinity Church, was erected the first regular hotel in our city. It was an imposing structure for so young a metropolis, and for a long time was the largest and most conspicuous building in New York. Prior to this time, taverns and private houses were the only places to which a traveller might repair for shelter, and the new hotel was a vast improvement. After a long career of unusual prosperity, during which time it was the scene of the famous "Bachelors" and Patri archs" Ball (the two great society events of the season) and entertained nearly all the distinguished visitors to New York, officially and socially, it was turned into an office building. The well-remembered Boreel Building succeeded the office building. Now the site of the magnificent twin office buildings, Trinity (No. I I I) and United States Realty (No. I 15 ).

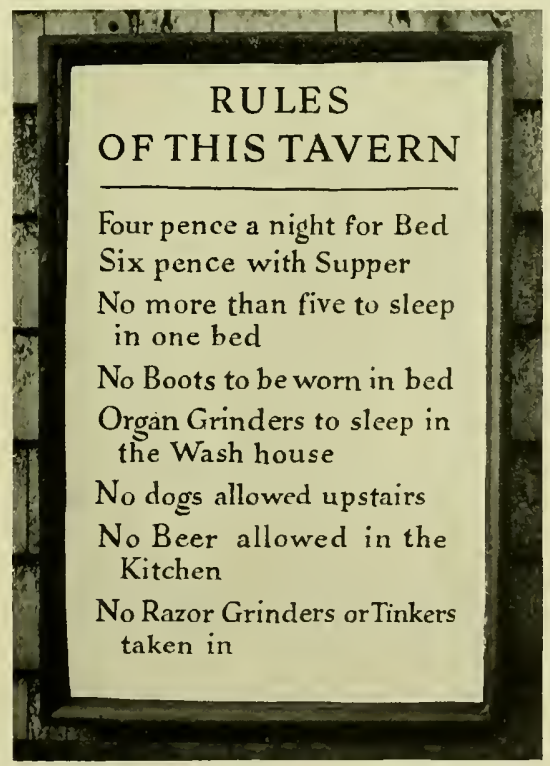

Collection of Mr. George A. Zabriskie

Âtr OII Time Taform Sign 


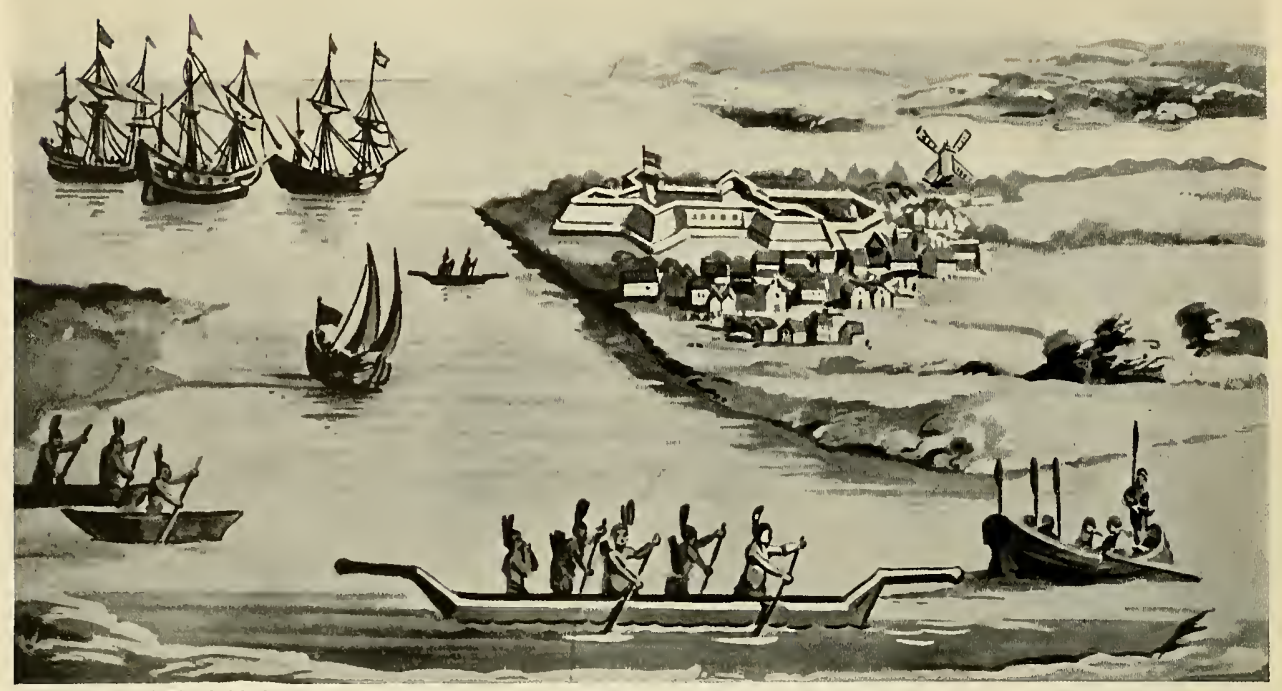

Courtesy New York Historical Society

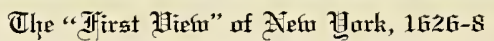

The first view of New York ever shown to the world. Date depicted, 1626-8. It was drawn by Kryn Fredericks, engineer of Fort Amsterdam, and for years hung in Peter Stuyvesant's Council Room in the Stadt House. It was finally sent to Holland, and rescued from oblivion by Adriaen Van der Donck, who used it in the first book written on New Amsterdam, and published by Joost Hartgers, Amsterdam, in $165 \mathrm{I}$. It is known as the "Hartgers View." The star shaped structure is the Fort, the site of which is now occupied by our present Custom House.

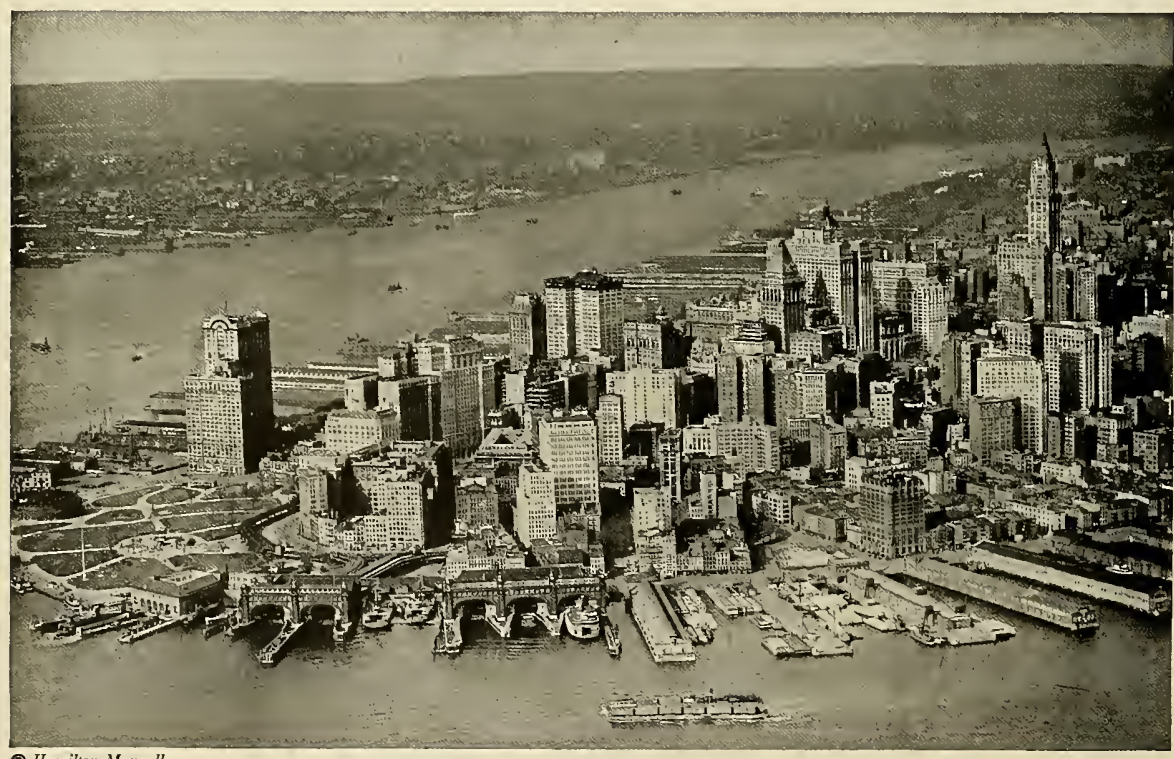

The Same Tlacation Tà̀u, 1922

View of New York today showing the" exact location depicted in the first or "Hartgers View" above. The Fort stood where the Custom House stands today. Skyscrapers replace the little houses clustered outside the Fort in the first picture. The open space at left is Battery Park; Aquarium at extreme left edge; foreground, tall structure, Whitehall building, where is the Government Weather Bureau. The two ferry slips, middle, are owned by the City, operating boats to Staten Island. At left is the Barge Office where emigrants are landed from Ellis Island. Captured "rum runners" caught by the Revenue Service, are anchored in slip next the Barge Office. This view covers the entire Financial section of New York. 


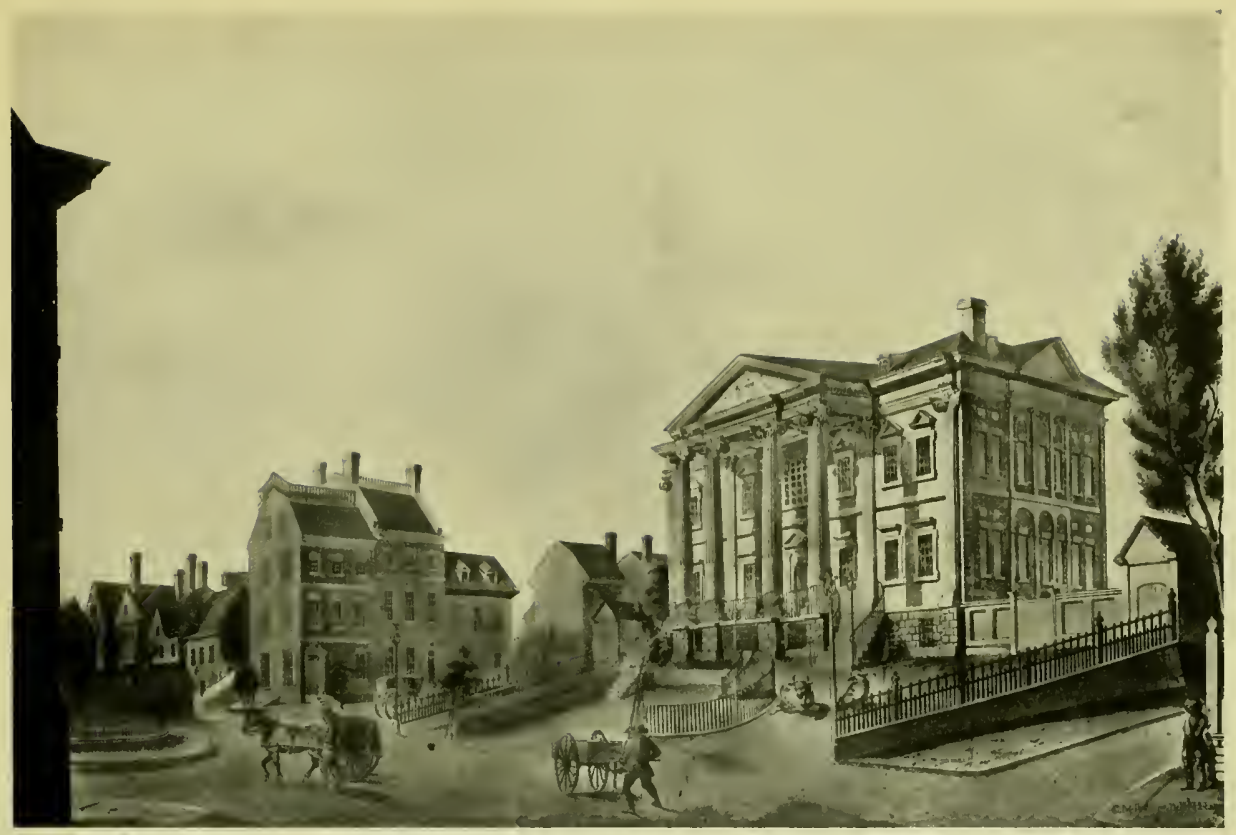

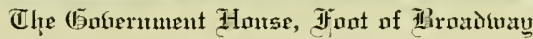

The Government House which succeeded Fort Amsterdam at the foot of Broadway. Frected 1790; burned 1815 . The Custom House is now on this site.

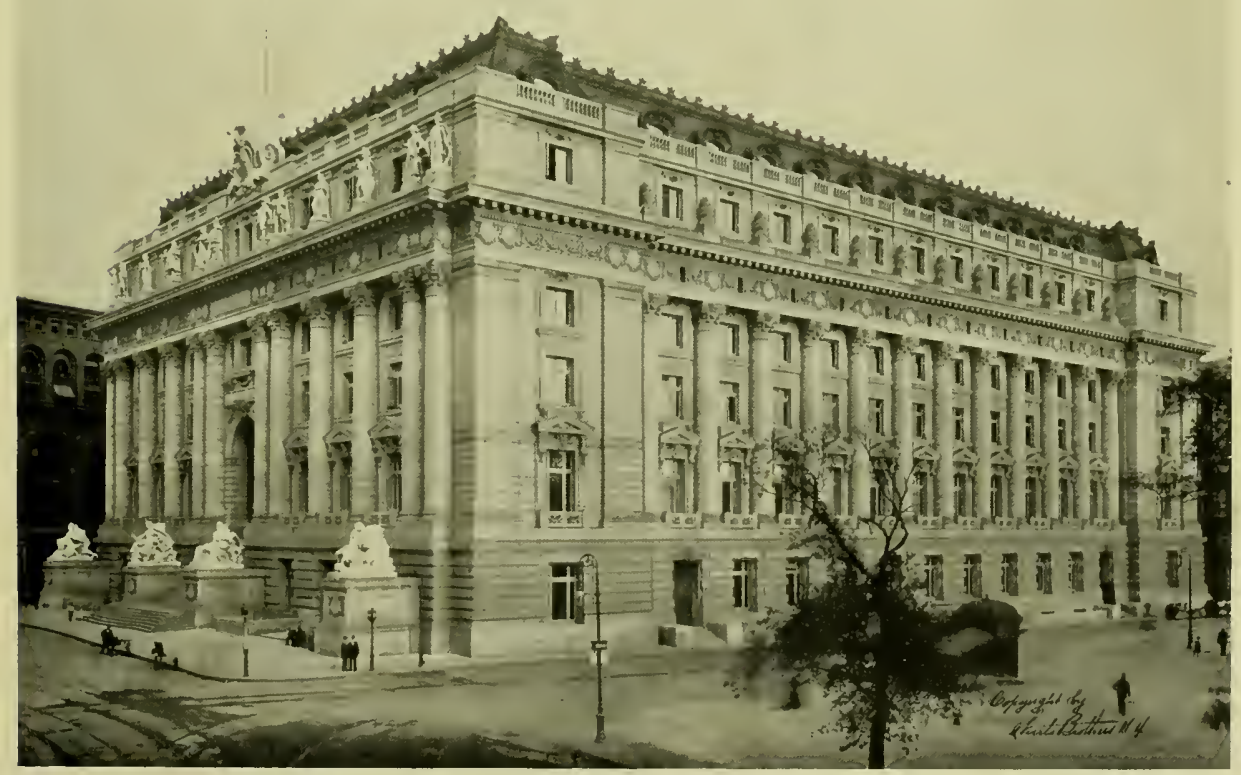

The Cristan Huntse

At the foot of Broadway on the same site on which stood originally Fort Amsterdam and the Government House. Old "Steamship Row," a row of brick houses preceded the Custom House. 


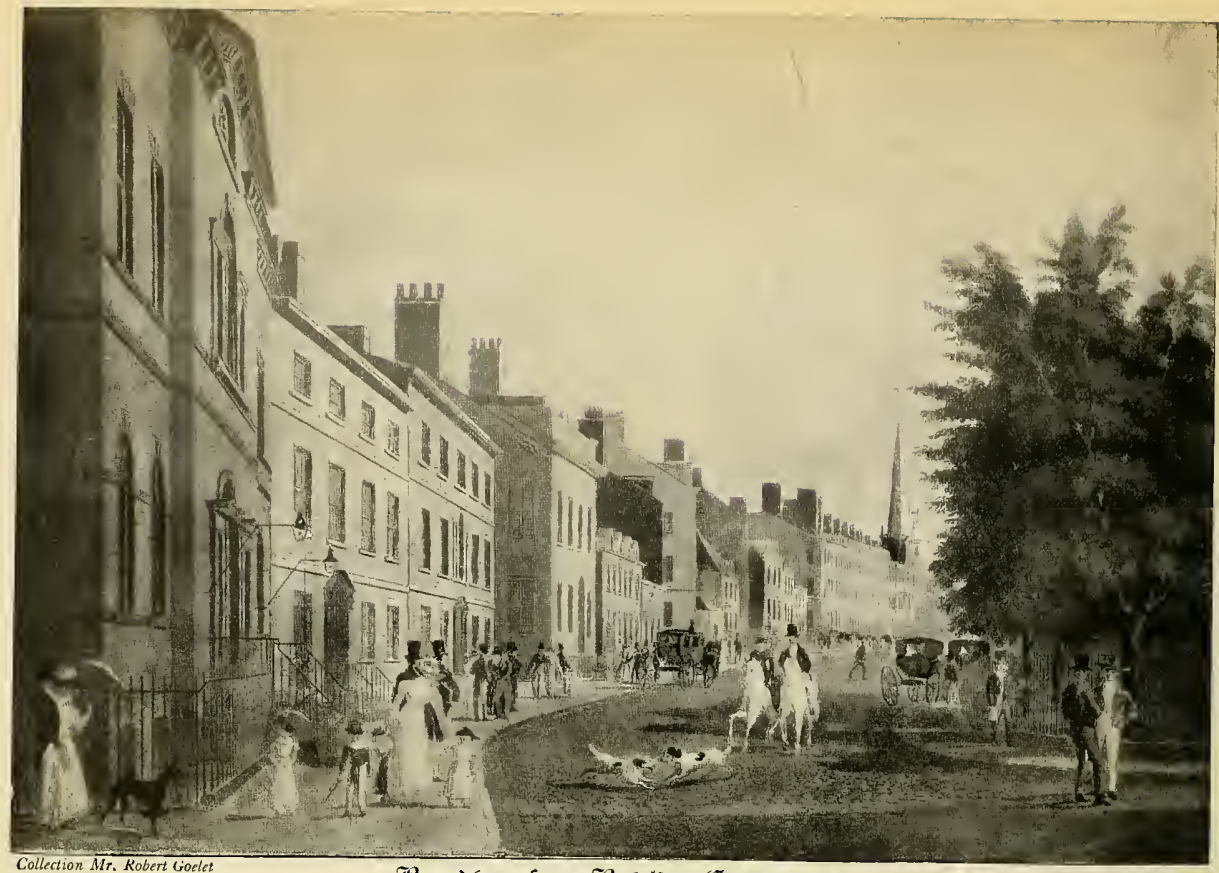

T⿱乛龰⿱⺈⿻コ一心

Looking up from No. I Broadway west side to Trinity Church, I825, showing Kennedy, Watts and Livingston houses (Nos. I, 3 and 5), built in 1760 . The Kennedy house was occupied by British officers during the Revolution. Robert Fulton died in the house which stood just in the rear. It was from the Kennedy House that Andre started out on his ill-fated journey to meet Arnold; and after the treason, Arnold was quartered in the Bowling Green Building, then a tavern called "The King's Arms." Daniel Webster iived at No. 17. P. T. Barnum and Jenny Lind boarded at the Stevens House, Nos. 21 to 27. This block now occupied by the new "Steamship Row."

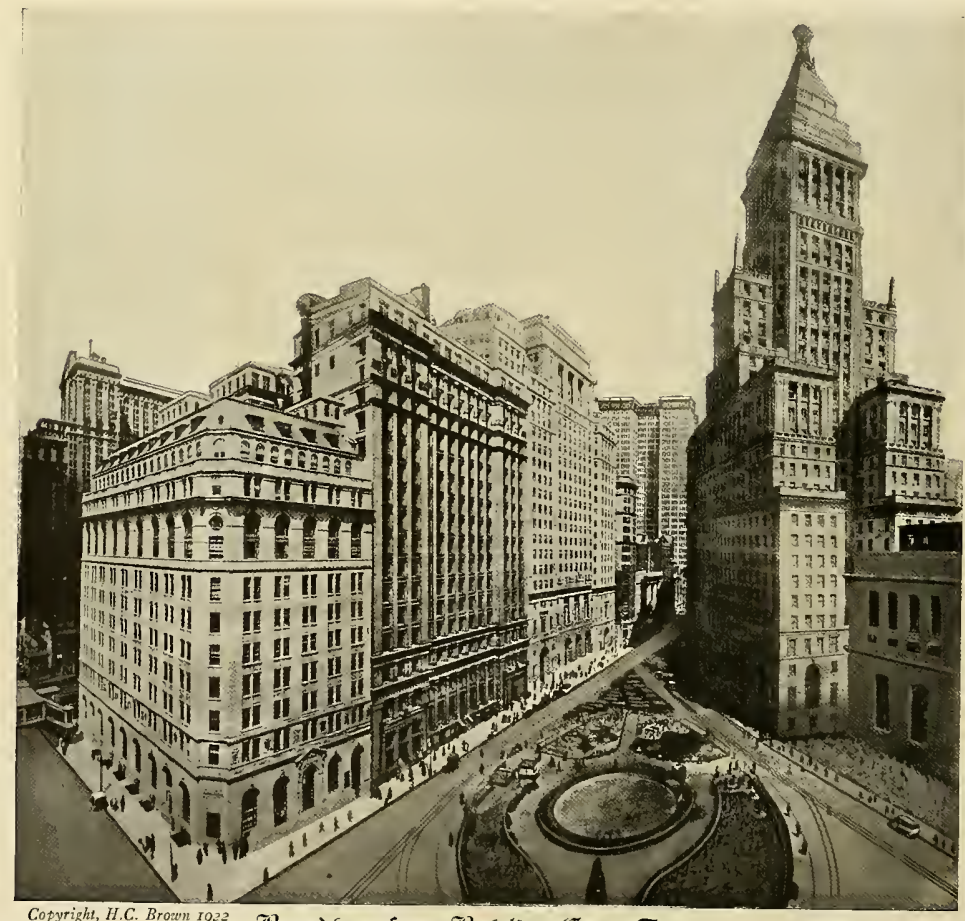

Copyright, H.C. Brown roz2 TRroathasty from Thufuling (Freen Todan

The same location, new Steamship Office Buildings also new Standard Oit Building, corner Beaver Street, at right, now in course of construction (1922). No. I Broadway is the first building at the left; part of the Produce Exchange shown at right; Bowling Green, our first public park, in centre. Here Washington reviewed the great procession to ratify the adoption of the Federal Constitution by New York. 


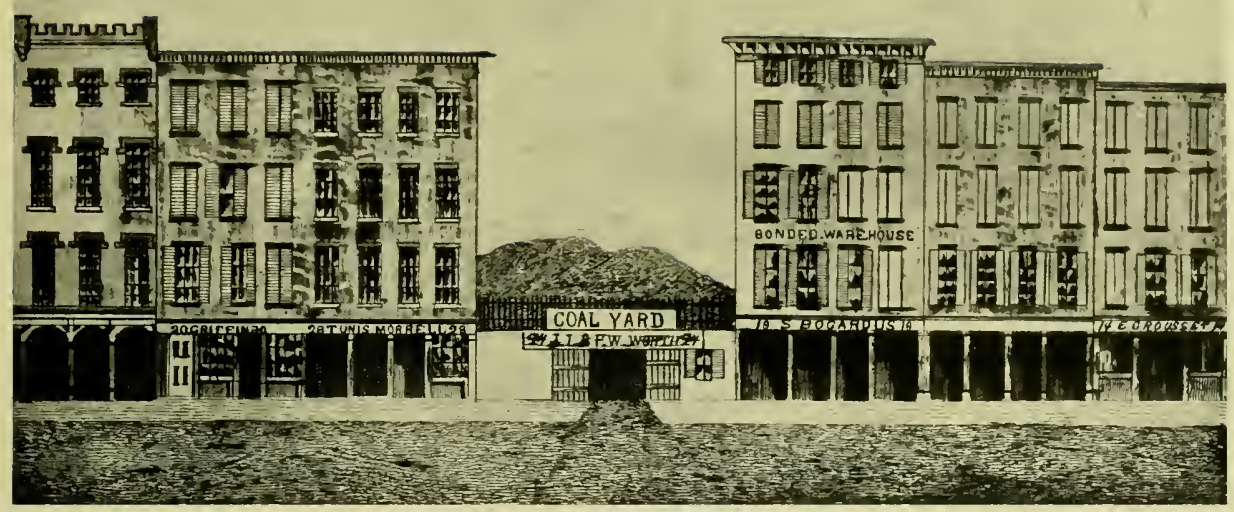

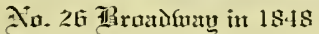

Present site of the Standard Oil Company's offices. The picture below shows the new addition to the building now under construction which extends the building to Beaver Street.

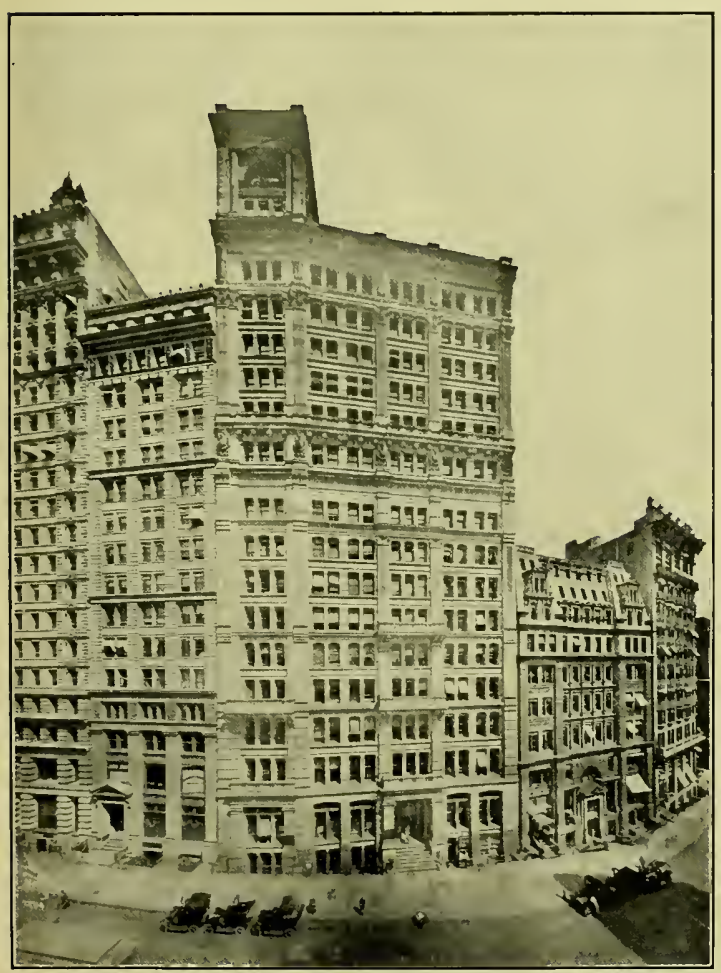

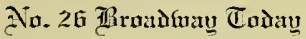

The entire block at right to Beaver Street will be added to 26 Broadway (see adjoining picture) making it the largest office building occupied by one corporation in the city

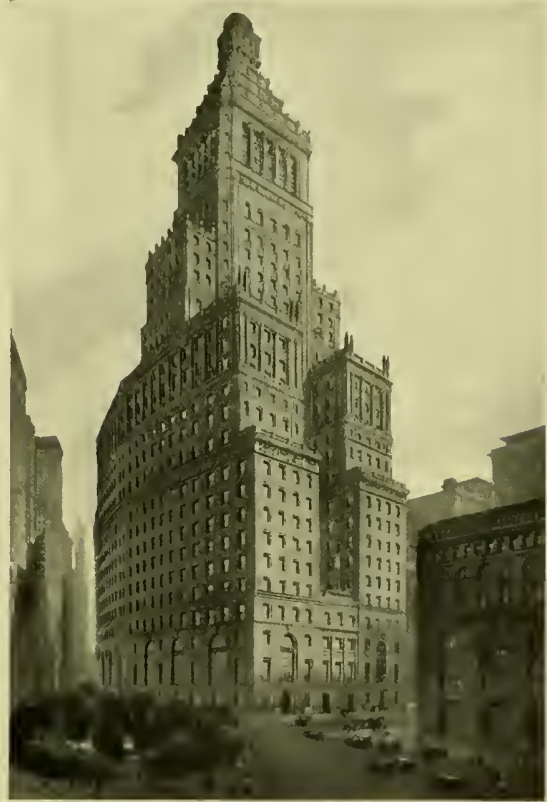

(C) II. C. Brown

No. 26 Throathanu Tomorrofu

Work on this new building is now well under way. When completed it will form an inspiring structure with which to start old Broadway. 


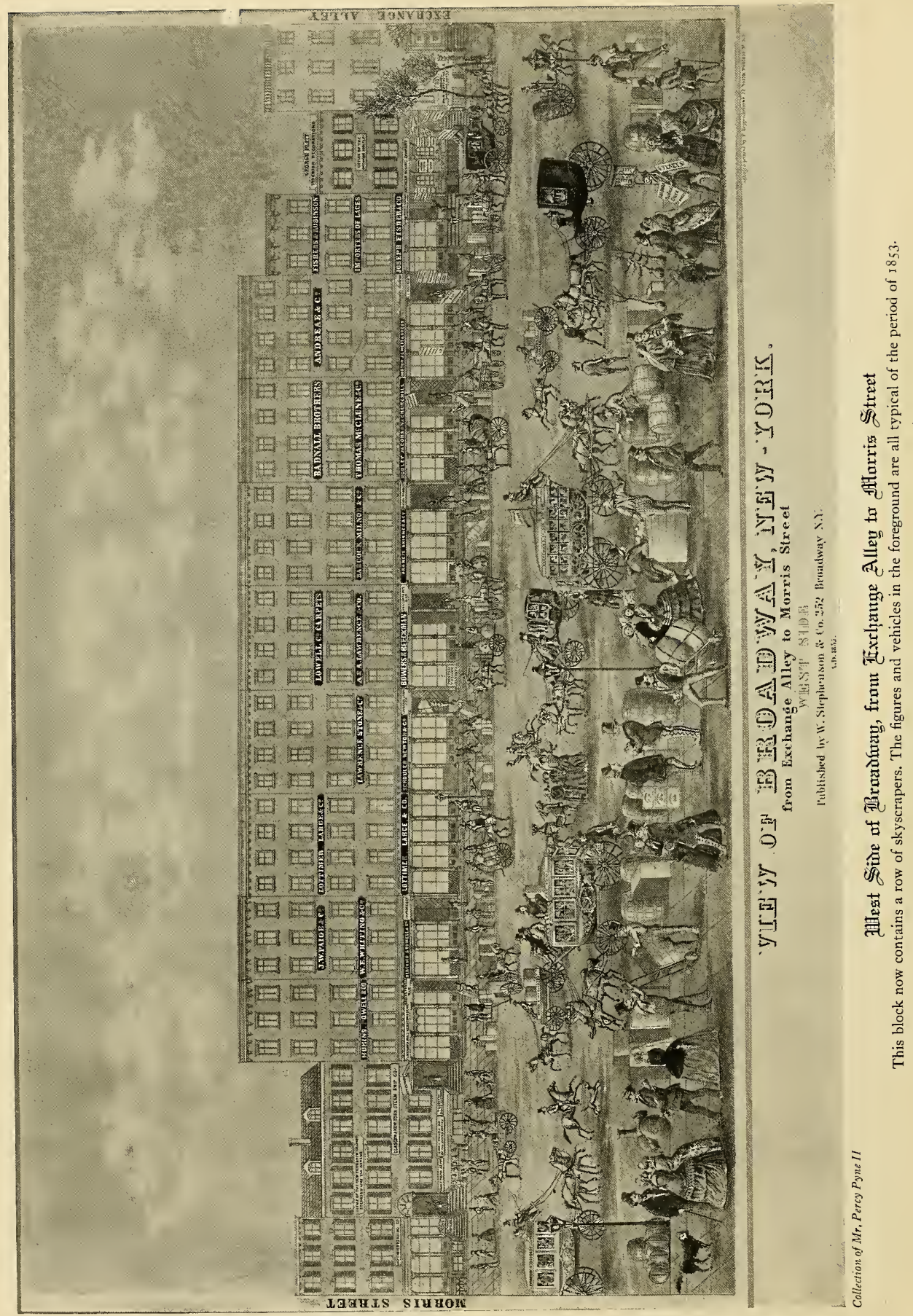




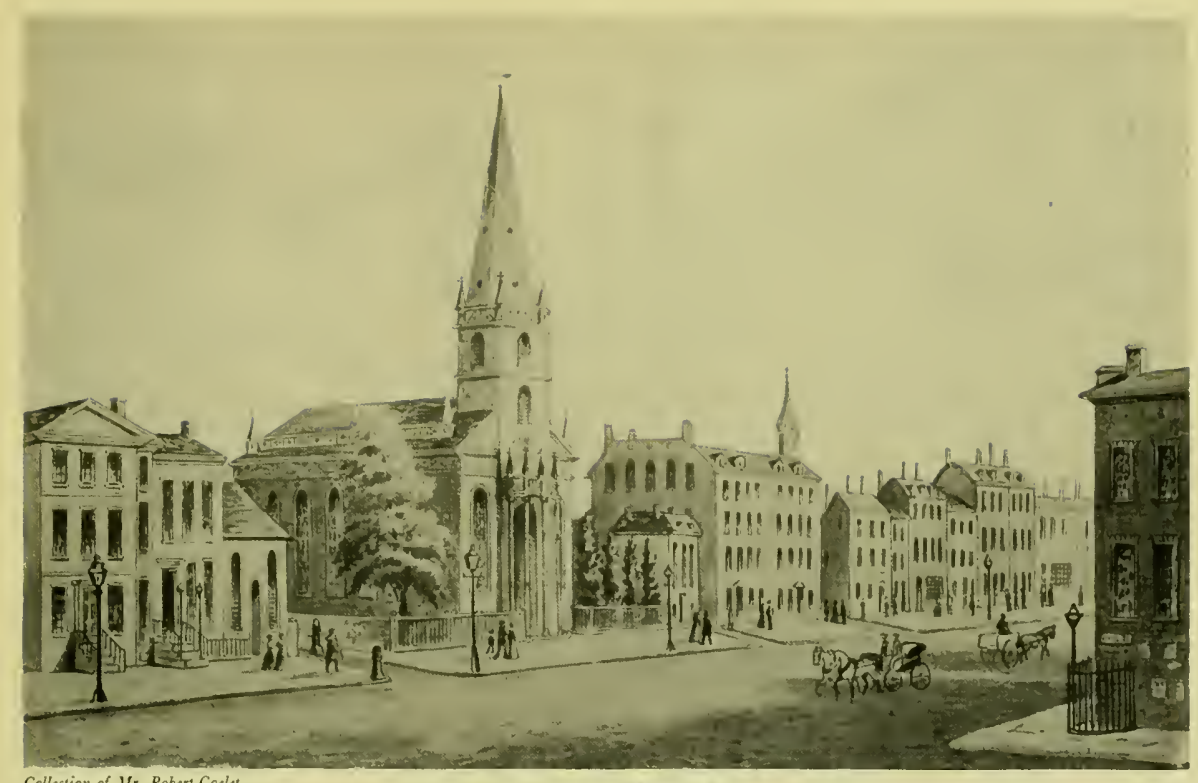

Collection of Mr. Robert Golet $\quad$ Ifirnatufuatu at Mllall Street

Broadway from Rector to Cedar Street, looking north, showing Grace Church, Trinity, New England House,
City Hotel, about 1835 . From a contemporary drawing.

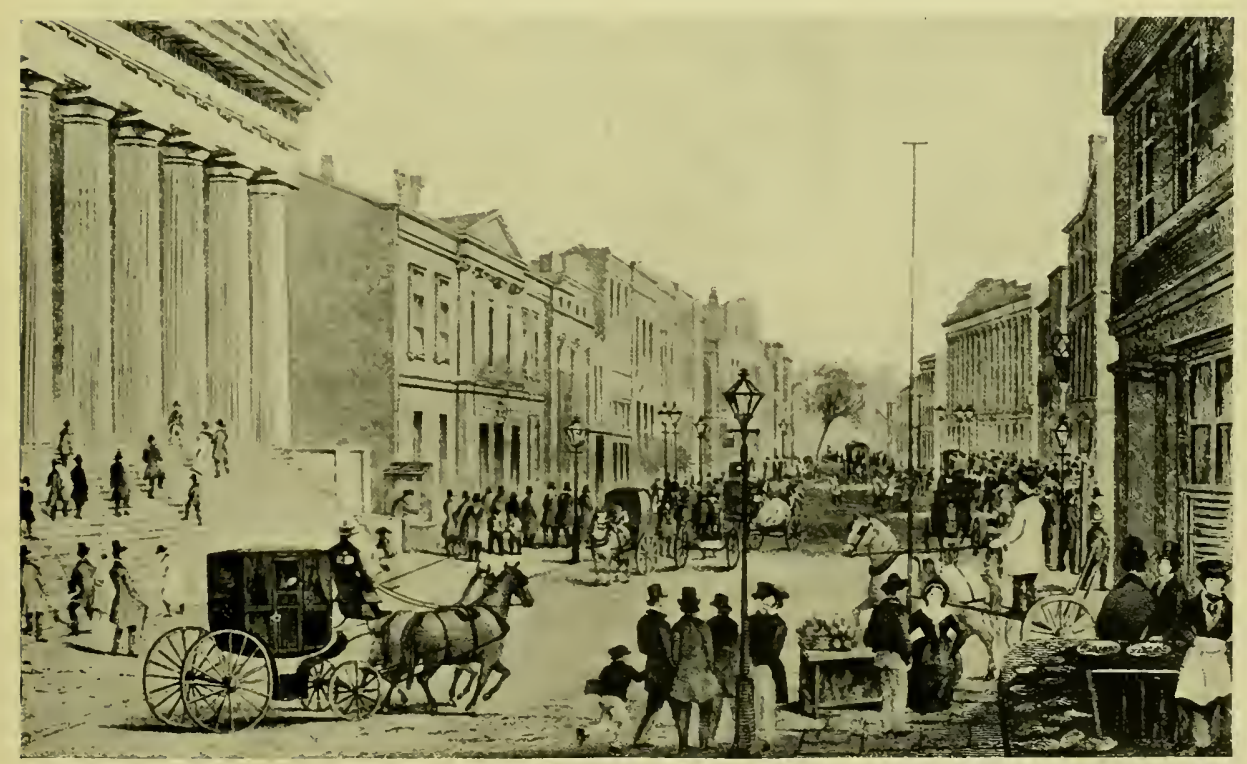

Allall Strent ahout 184 s

From the Sub-Treasury, looking east. From a contemporary drawing. 


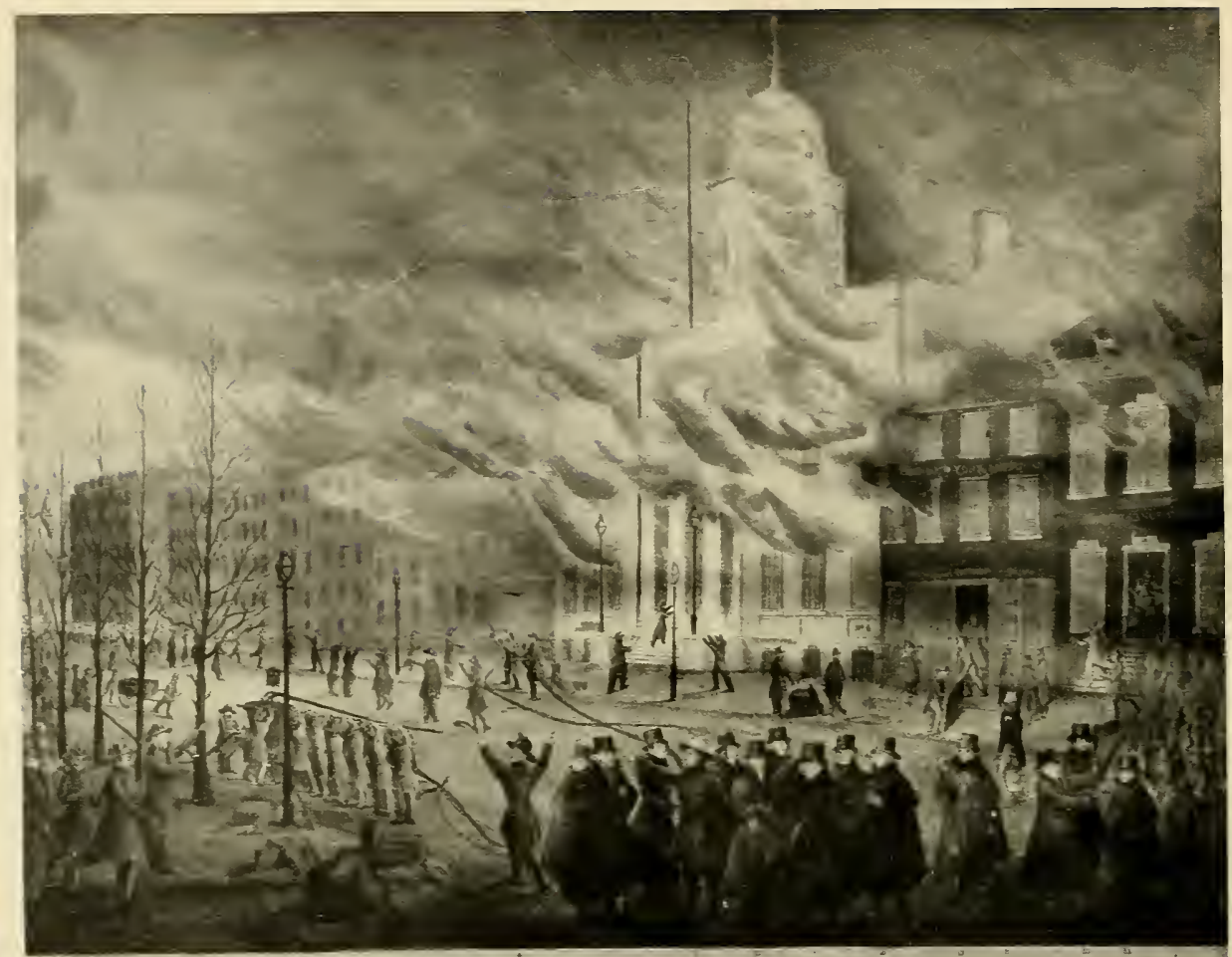

THE GREAT FIFE OF THE CITY OF NEW-YORK, i6 OLCEMBER 1835

Collection of Mr. Robert Goelet

\section{The (breat Ifire of 1833}

A very rare and interesting picture of the Great Fire of 1835 , in which the main business portion of the city east of Broadway and south A very rare and interesting picture of the Gich loss of over thirty millions of dollars. In less than a year, however, the burnt district was entirely rebuilt. The figures in the foreground were of eminent merchants of the day who were among the volunteer firemen who helped save the citr. The gentleman running up the steps, wished, if possible, to save the statue of Alexander Hamilton, which was destroyed a few minutes afterwards. "Vr. Chas. King (President of Columbia College) is the gentleman who crossed the East River that awful night in an open boat to the Navy Yard to procure gunpowder, in which he was successful." The National City Bank now occupies this site.

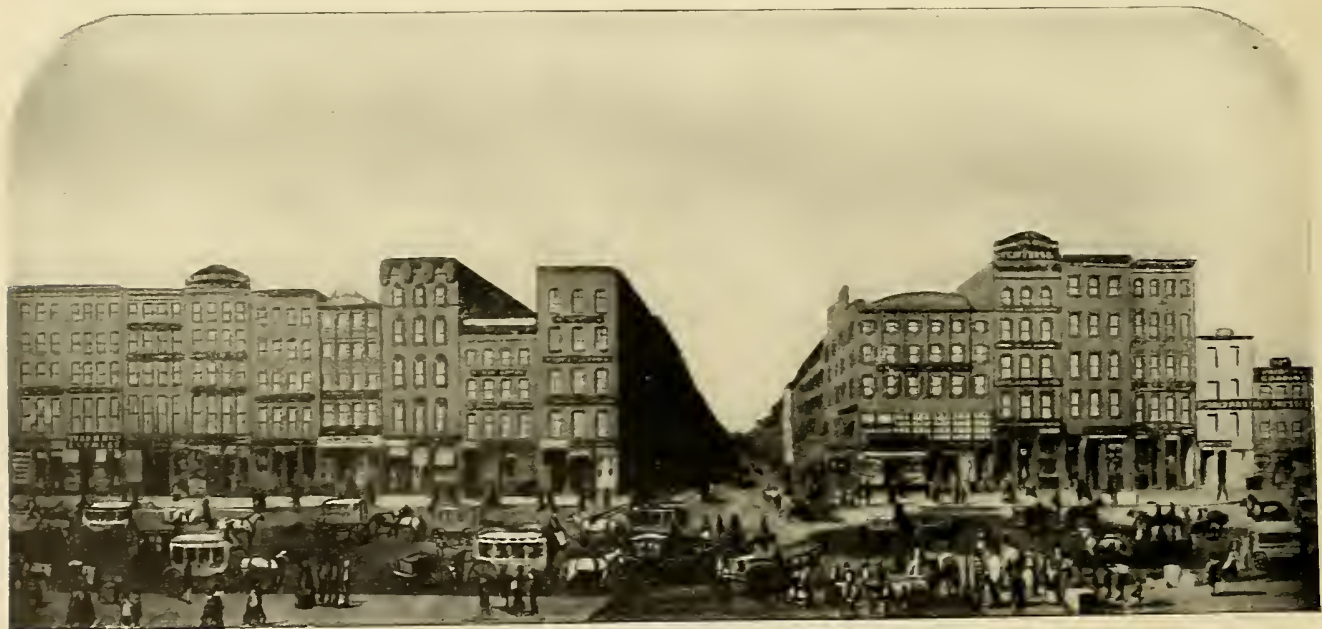

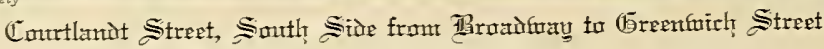

This view shows Courtlandt Street before Church Street was opened, 1853 . From a contemporary lithograph issued by W. T. Stephenson 


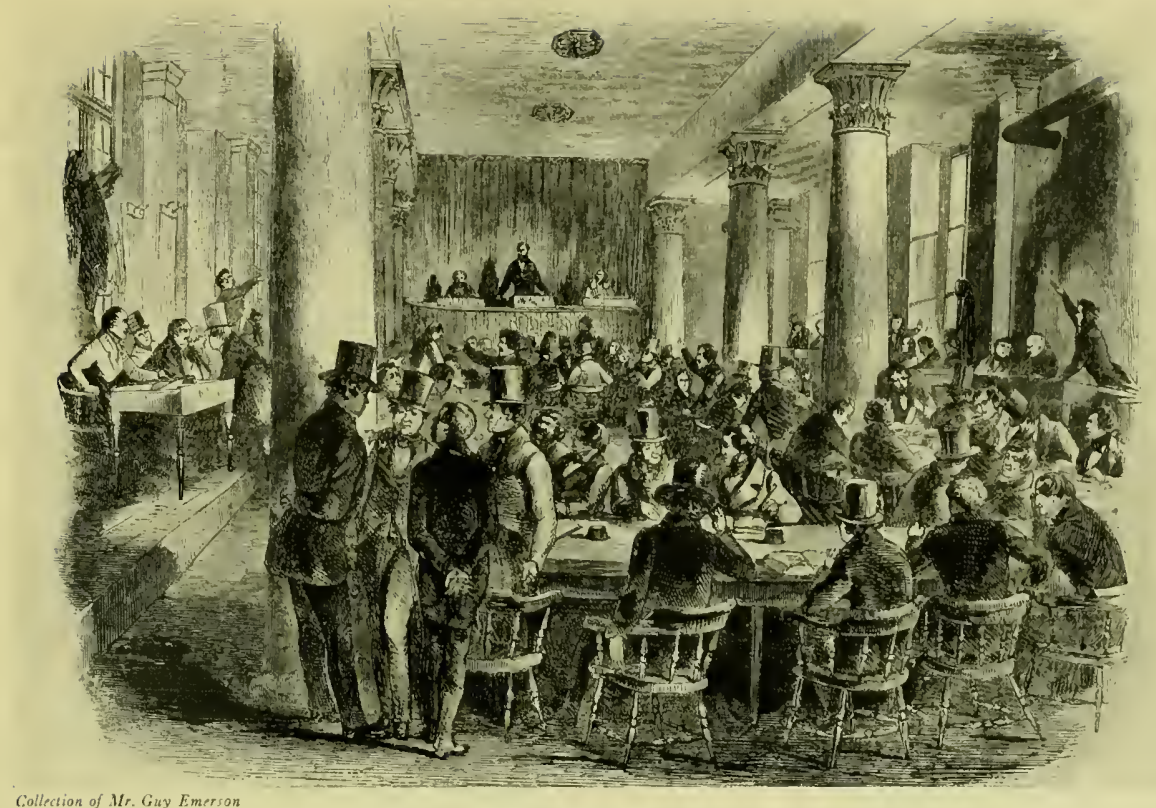

Illuteriur of tḷe Stark Exxhanguge in 1853

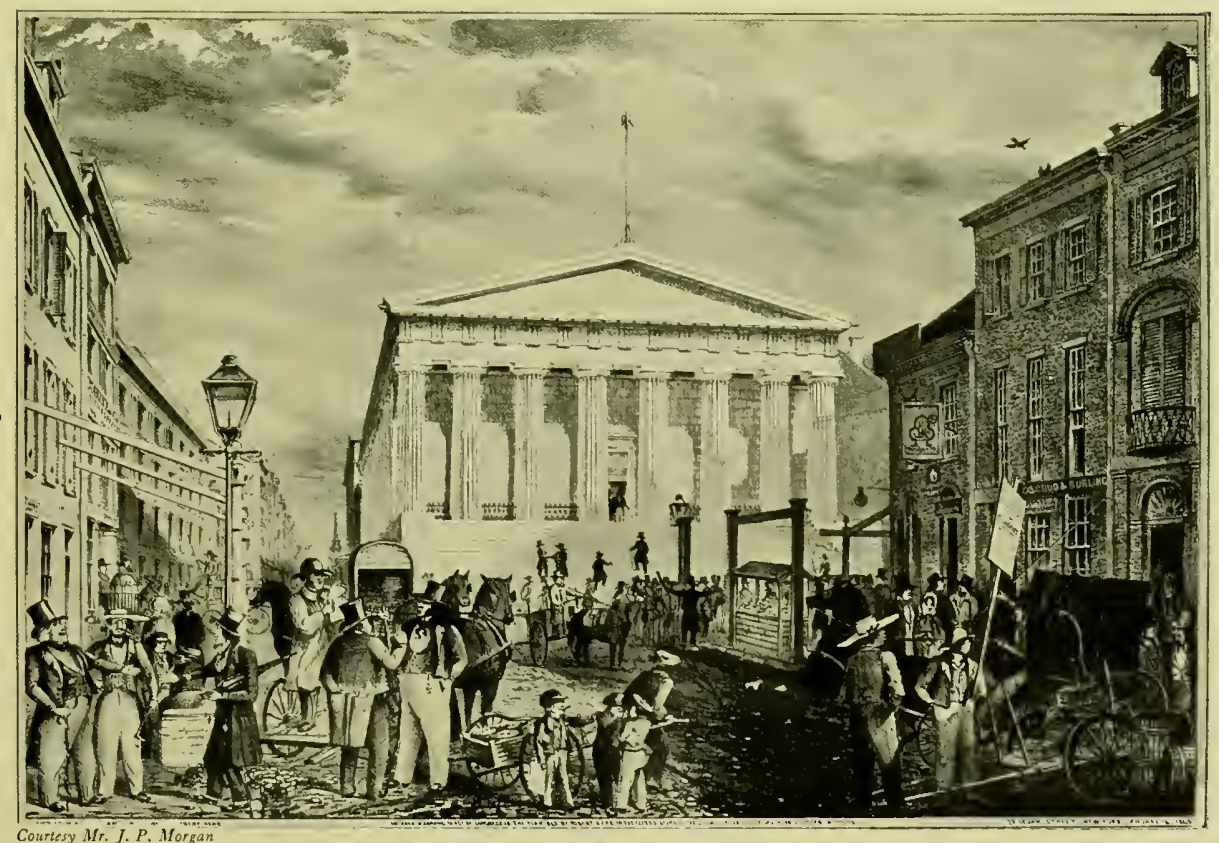

The Uustoum Thourse, alhaut 1845

A view on Broad Street in front of the Stock Exchange and Sub-Treasury (then the Custom House), showing the old Oyster Stand that formerly stood in front of the Mergan Building, about 1845. The present Stock Exchange Building begins where the lamp-post shows at the left. 


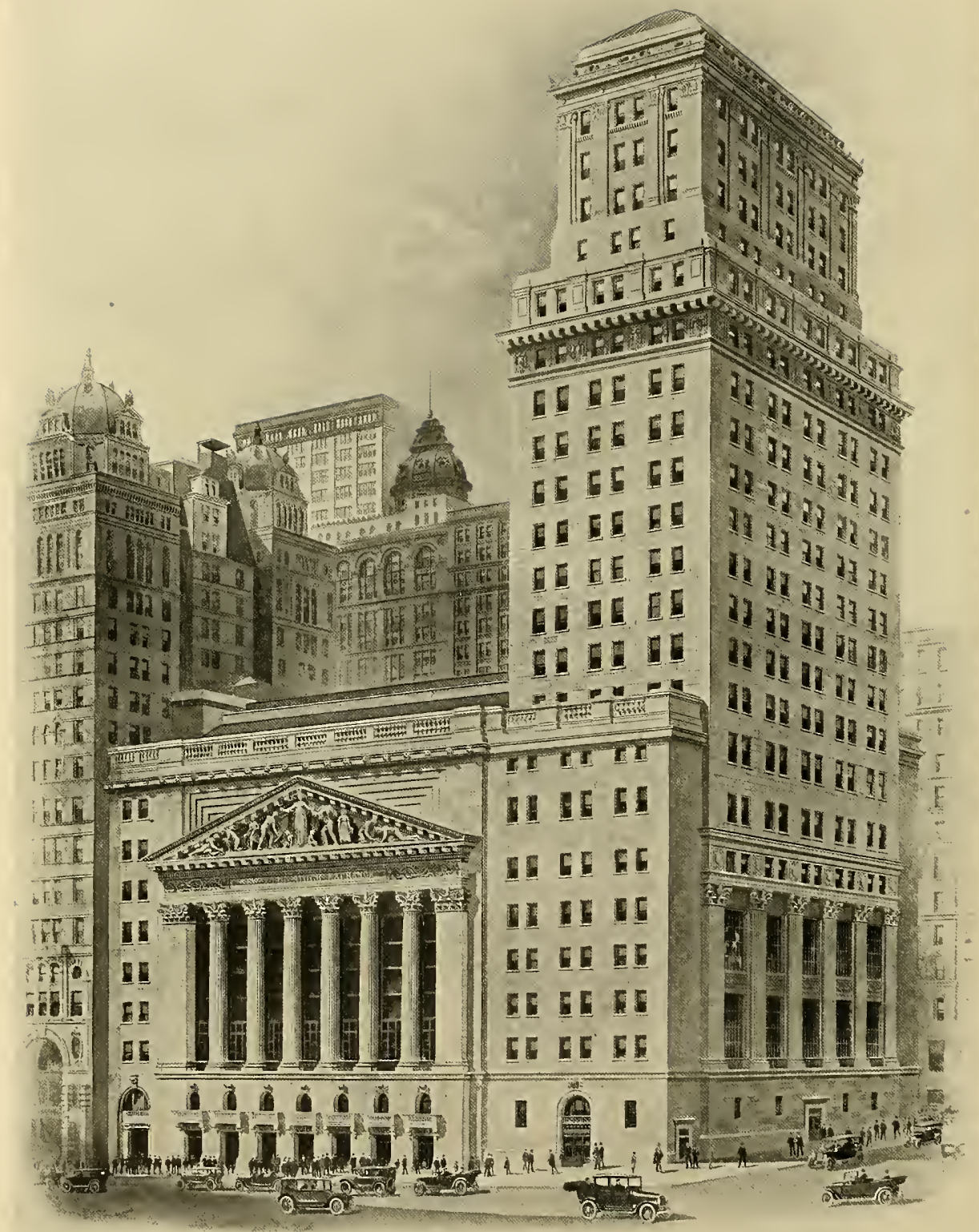

Thye Stork Fixtḩunge

The Stock Exchange Building with its new annex at the corner of Wall and Broad Streets, 1922. 


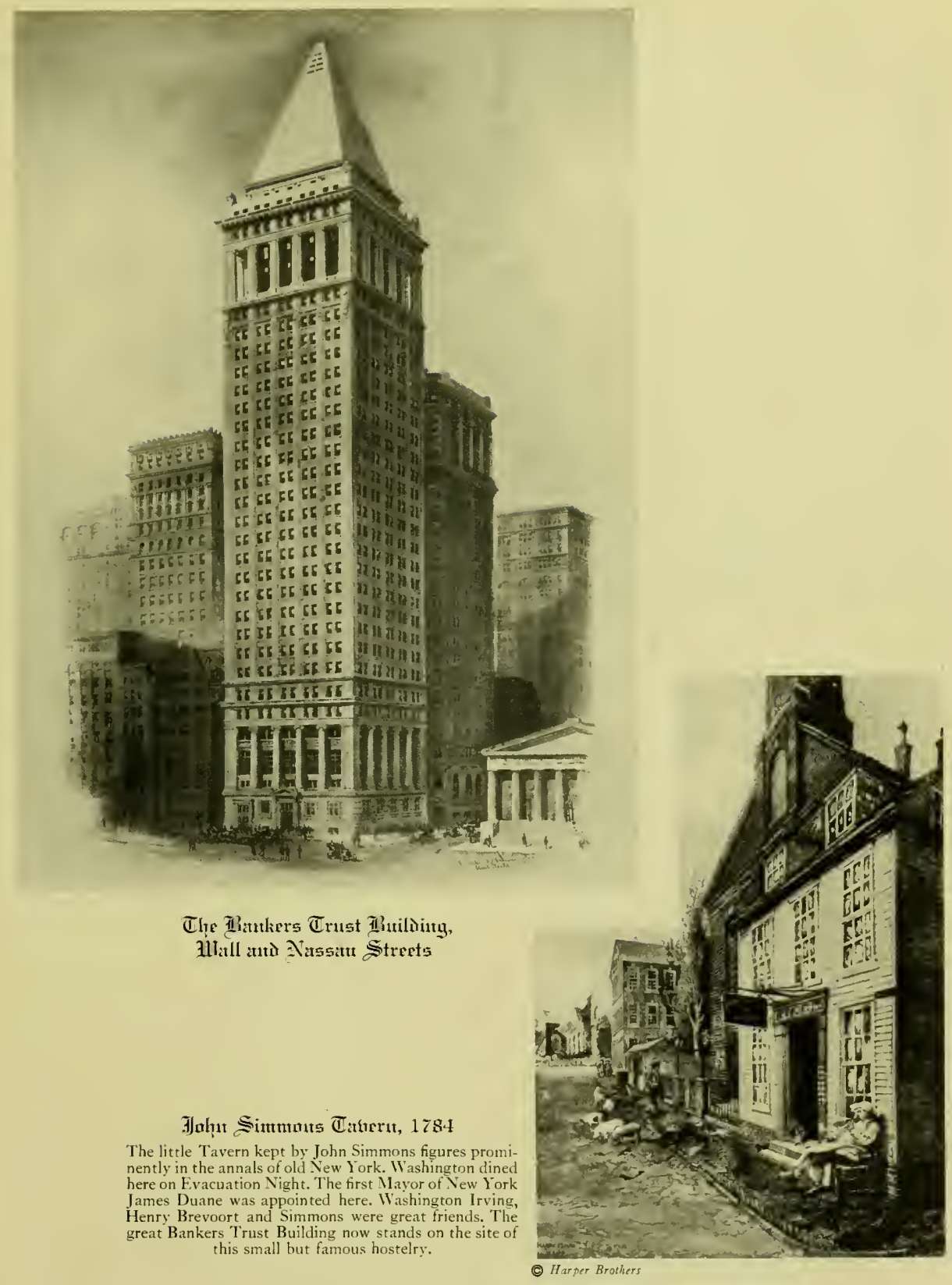




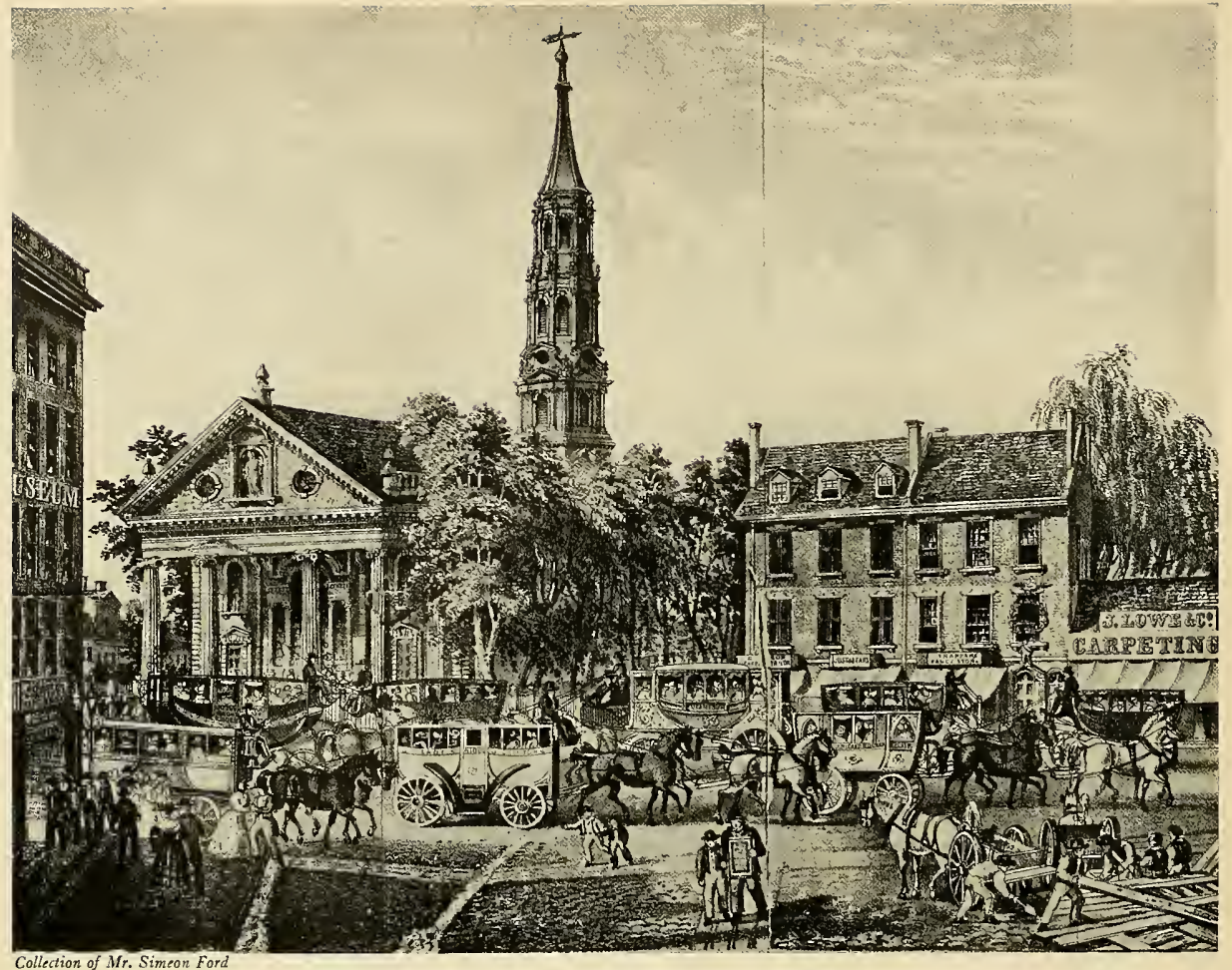

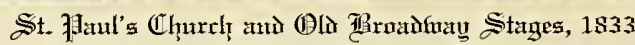

The three small buildings were removed to make way for the Astor House. William Henry Harrison, "Old Tippecanoe," studied law in the building at the right with the sign "J. Lowe \& Co."

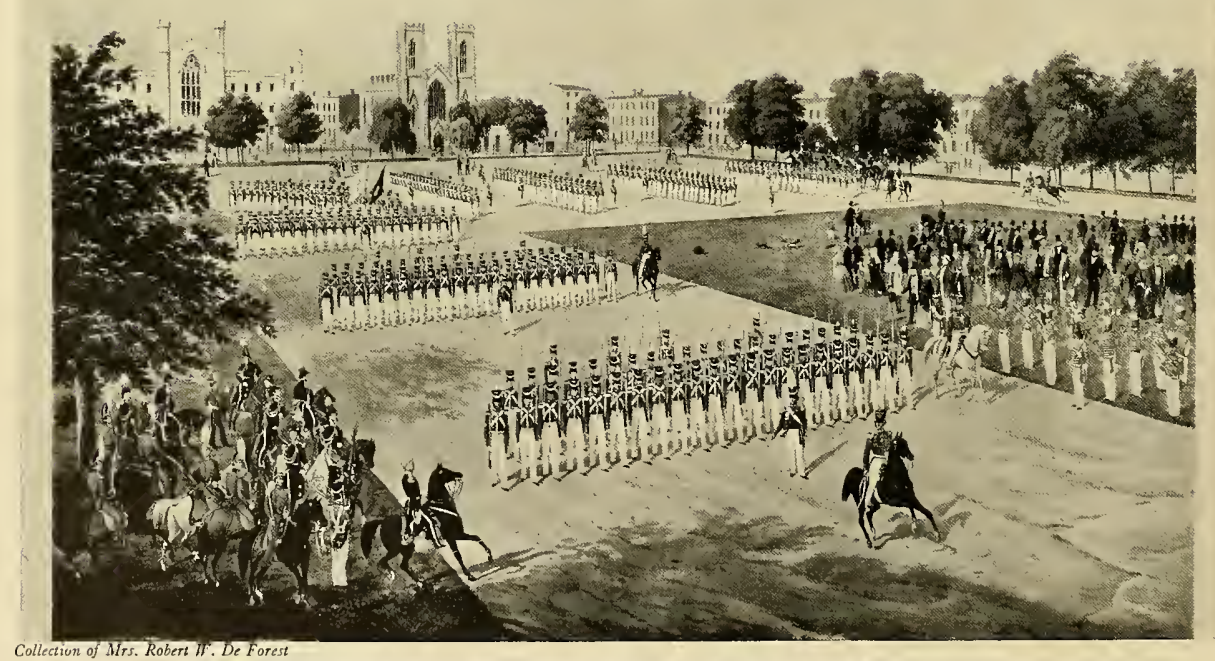

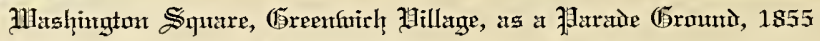

It was Potter's Field, 5789 -1 82.3; made a Park in 1827. Buildings of the New York University are at upper left. Each face in this picture represents an actual portrait of a member of the 7 th Regiment, one of the crack State Military organizations, here shown at annual inspection drill. 


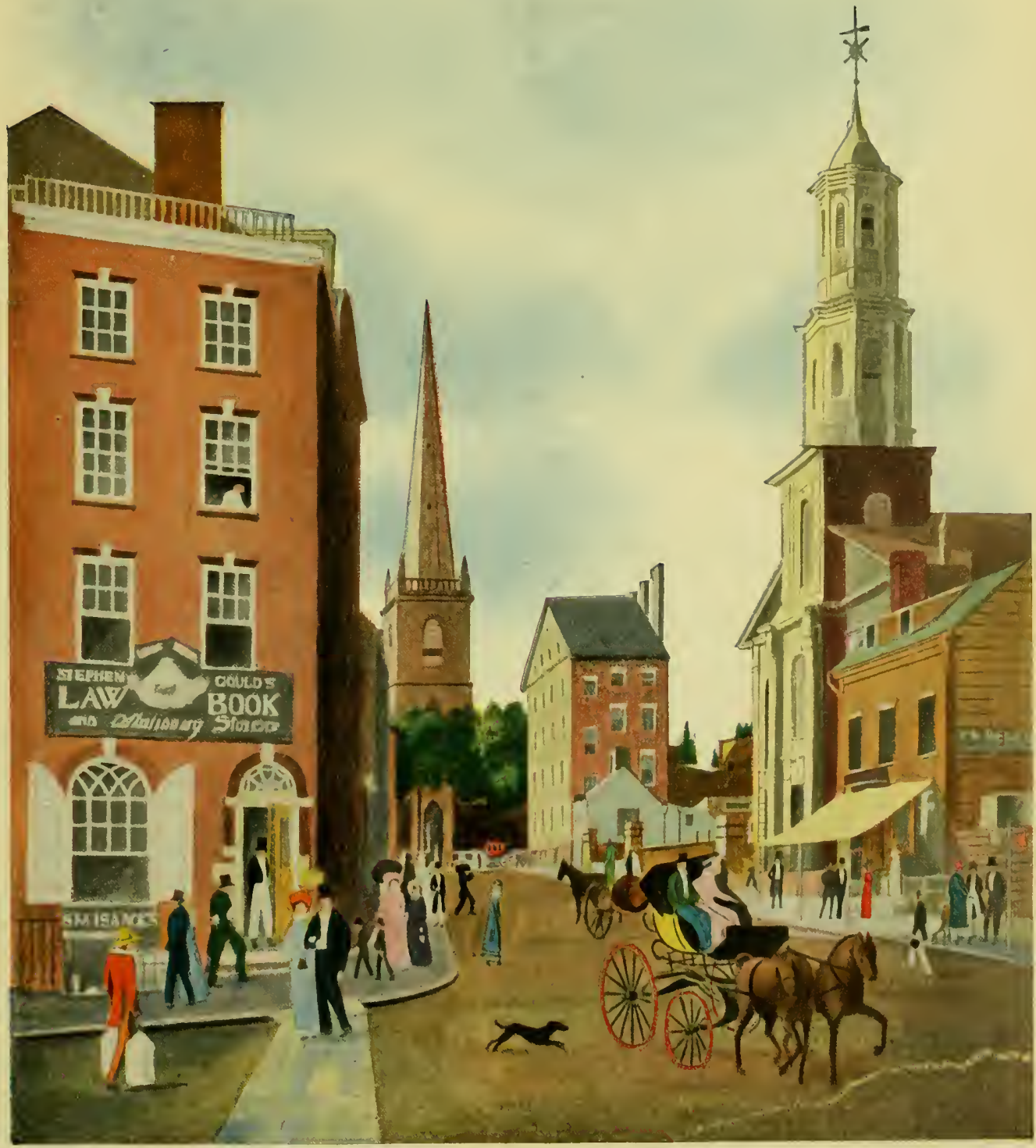

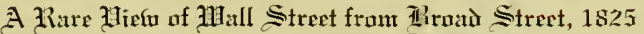

A unique sketch of contemporary date, giving an excellent idea of street traffic and costumes of that early period. The corner at the left (Law Book) is now occupied by the new addition to the Stock Exchange. Back of this was Josiah Hoffman's law office where Washington Irving studied law. To the rear of what is now the new Stock Exchange building is a small street called New Street because it was "new" when the Dutch burghers first built it three hundred years ago and the name has never been changed. The church in the center is, of course, old Trinity. The tall building with steeple is the First Presbyterian Church, used as a hospital during the Revolution. This church is now on Fifth Avenue near 12 th Street. The little two-story wooden building with the awning was a famous tavern in its day kept by John Simmons. Washington dined here and the first

Mayor of New York was appointed here.

Owned by I. N. Phelps Stokes in "Inconography of New York." (-) 


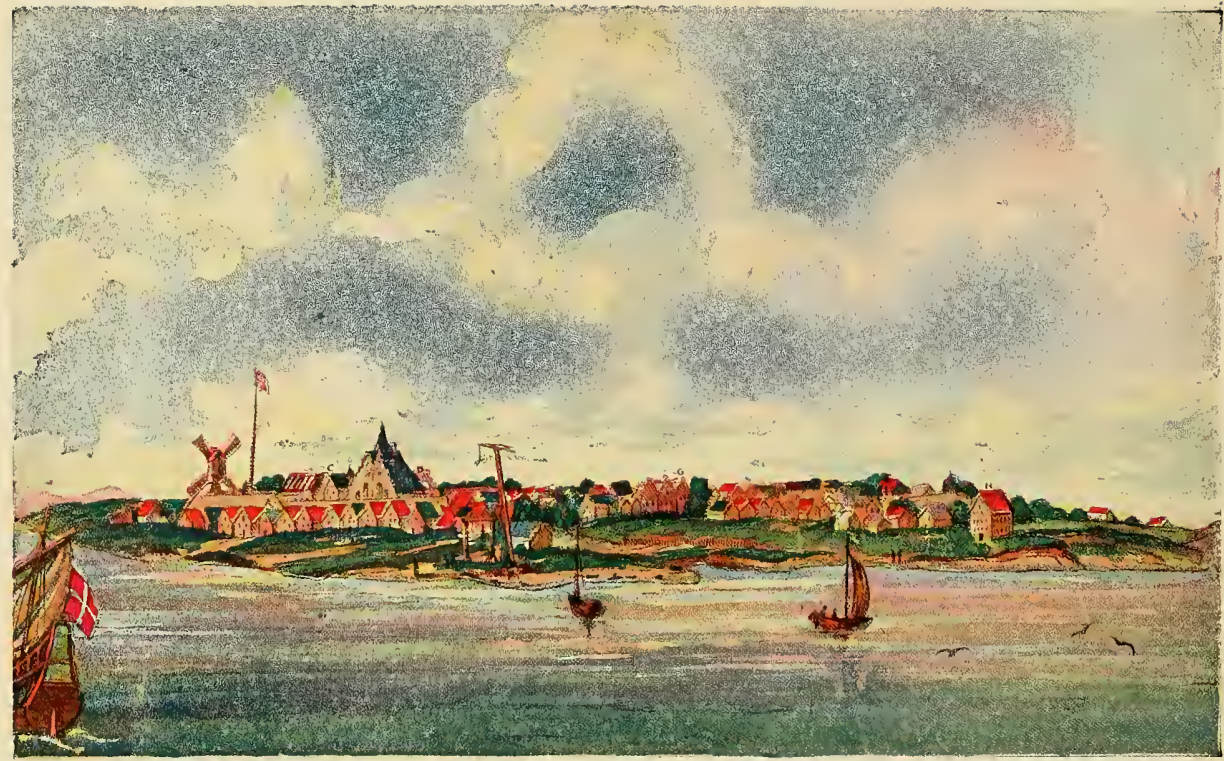

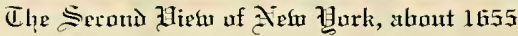

This view, known as the "Yisscher View," shows the city about twenty years after the one shown on another page. Already the little settlement gives signs of growth. The picture shows Pearl Street as a pretty shore road with a pebbly beach running down to the water (in the center of the picture).

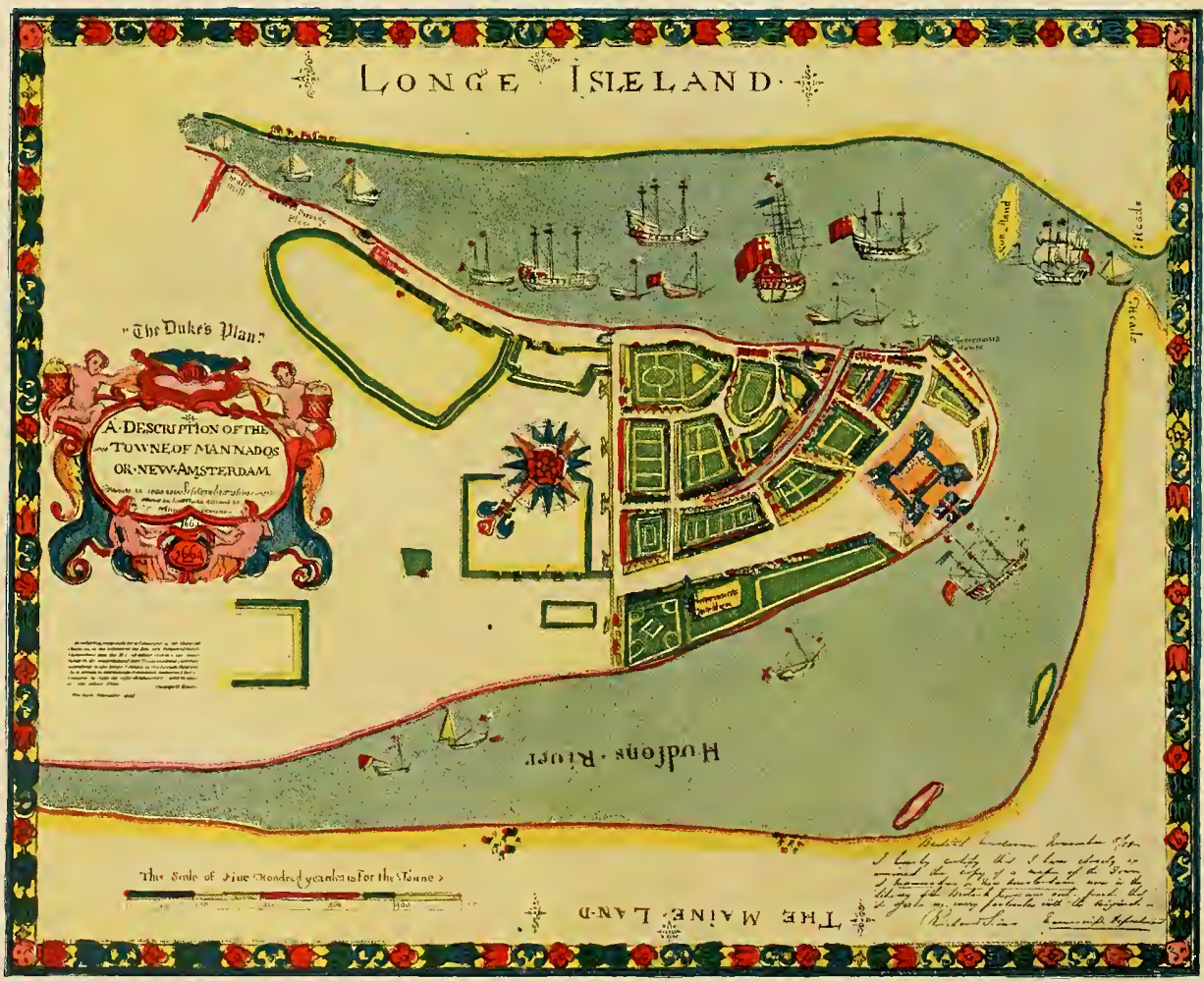

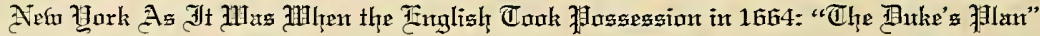

This remarkable drawing was owned by George III, who bequeathed it to the British Museum along with other items pertaining to his lost "beloved" colonies in America. It shows how the town looked when it was first taken from the Dutch. The wall or stockade where Wall Street now stands is one of its most striking features. The Duke of York for whom our city is named is credited with having drawn this map based on the Nicoll's survey, hence the title. 


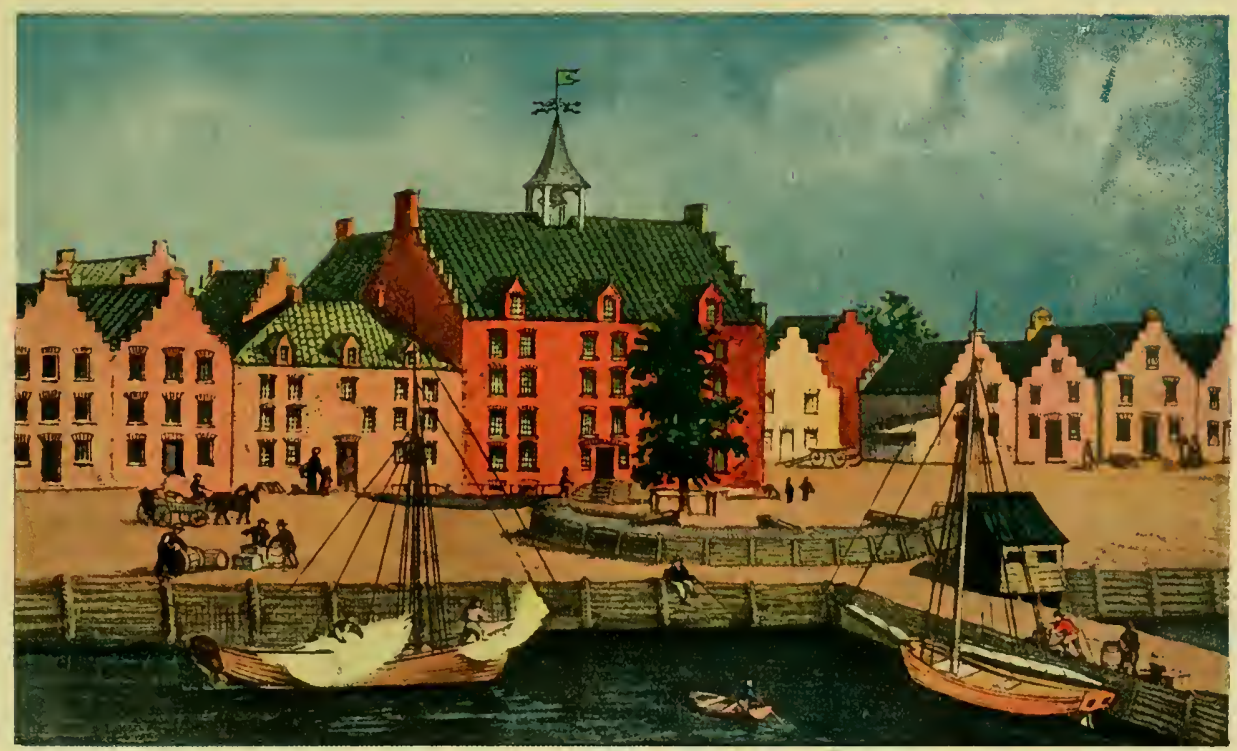

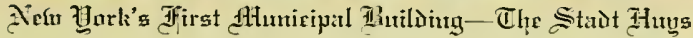

Located at the corner of Coenties Slip and Pearl Street, which then faced the river, this building sheltered the eariy Burgomasters and Schepens and other city officials. The home of Governor Lovelace, afterwards a tavern, adjoins it on the left. The St. Nicholas Society owns a copper wind-vane, presented to it by Washington Irving, which is supposed to have come from the cupola of this building when it was demolished in 1700 .

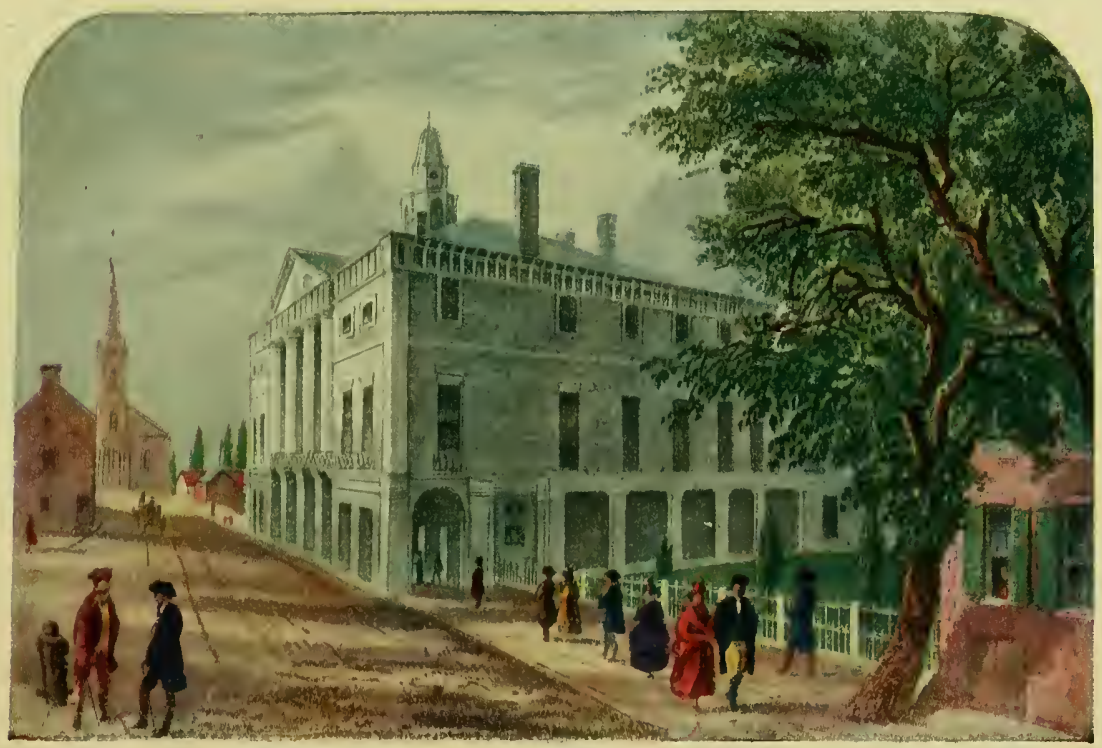

The Tirst Capitol Tituilititg of the thuitè Statrs

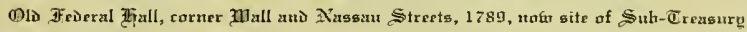

In this building Washington was inaugurated President. It was here that he signed the papers creating the Supreme Court of the United States. It was here also that he appointed Jefferson minister to France. Hamilton's greatest achievements were planned and largely executed within its walls. 


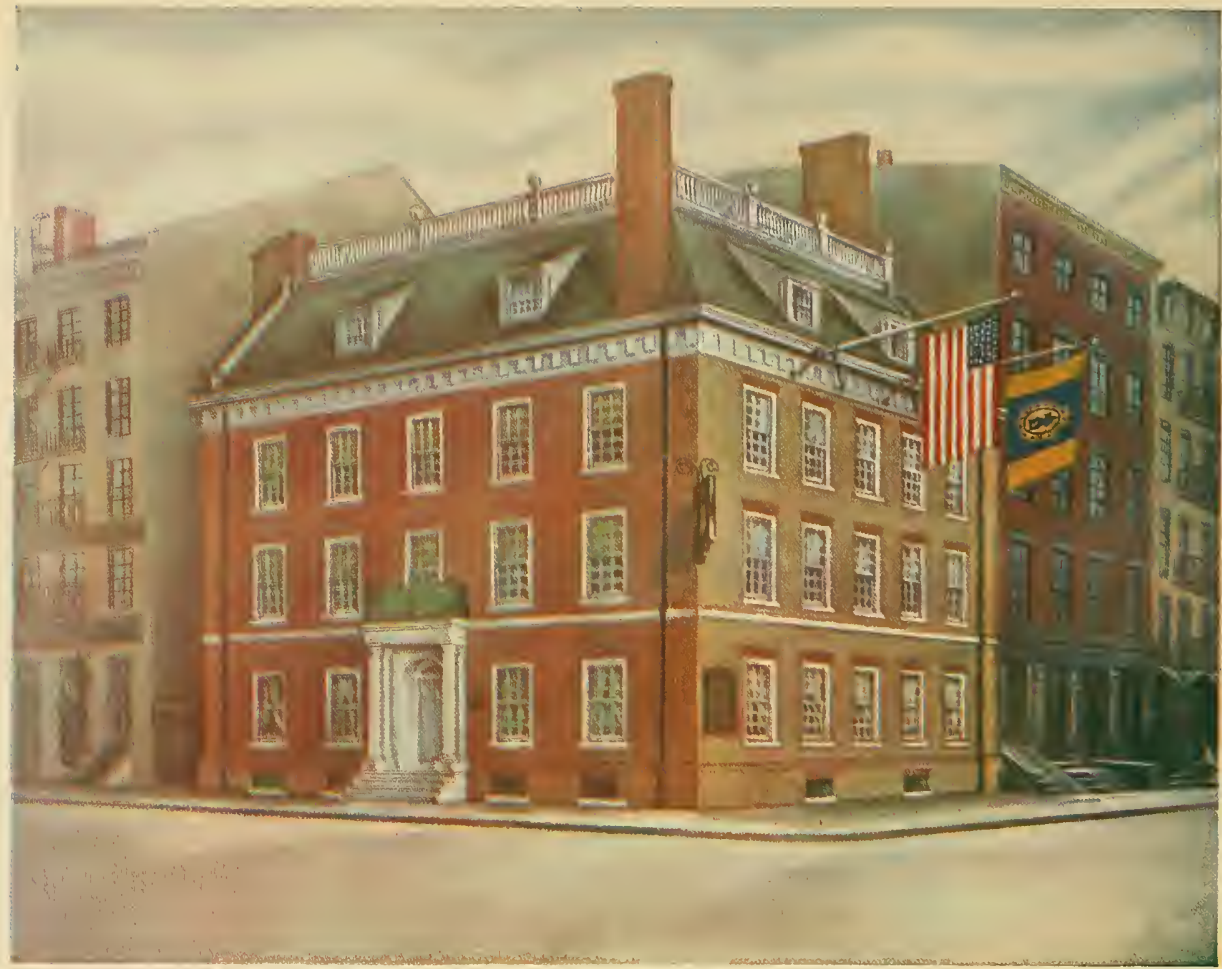

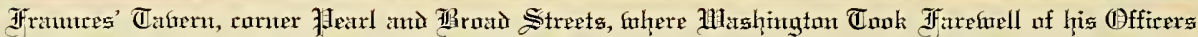

Fraunces' Tavern is one of the interesting buildings in New York, and was the scene of many stirring events during the Revolutionary period, It divides honors with St. Paul's Chapel, Washington's Headquarters and the Roger Morris Mansion in its connection with memories of Washington in New York. In the "Long Room" occurred the affecting scene with his officers, during which, for the last time, he took leave of his comrades-in-arms and retired to Mount Vernon. From the Collection of the Sons of the Revolution

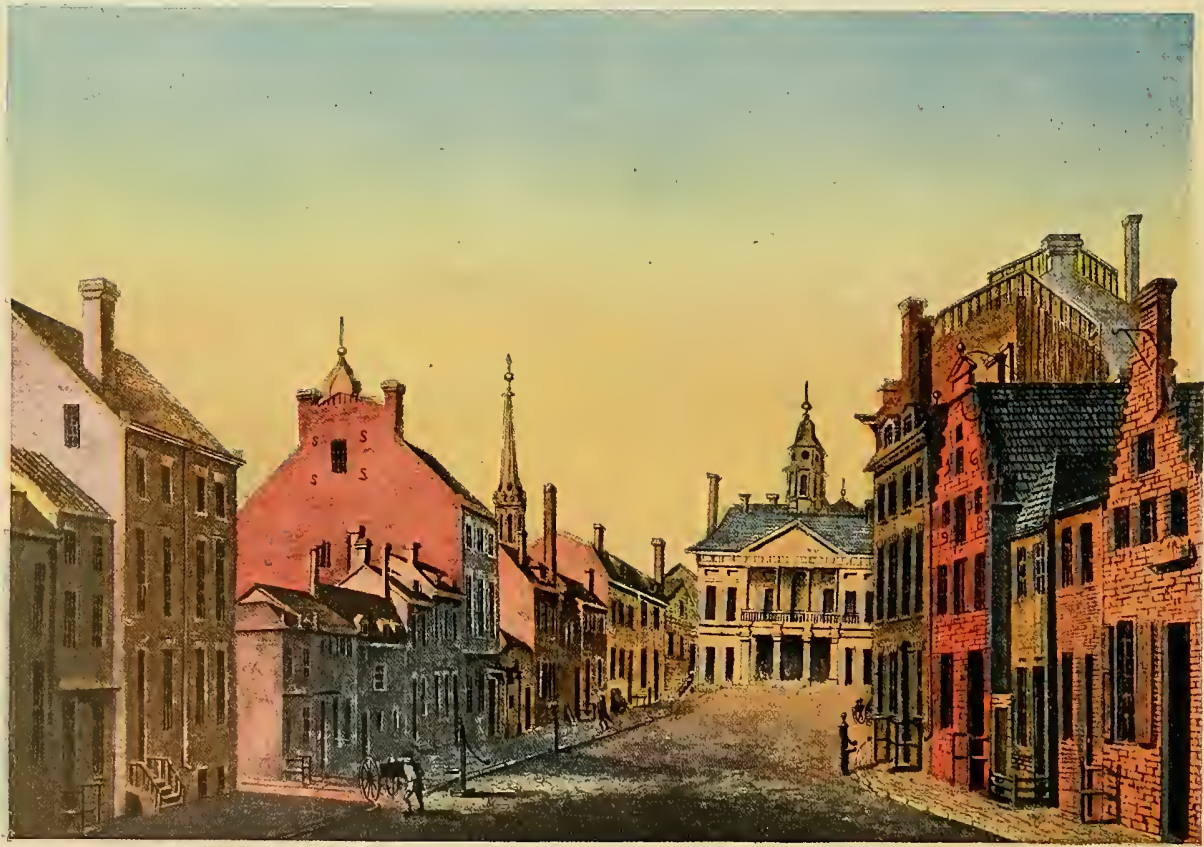

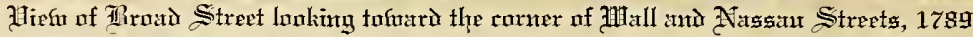

This interesting view shows Broad Street from below Exchange Place to Wall Street, including the sites now occupied by the Stock Exchange and other large buildings. Federal Hall, at the end of the street, was for a brief period the seat of Congress when this city was the Nation's Capital. When this building was removed Nassau Street was opened through the site, and the present Sub. Treasury was built somewhat to the right. During the Dutch period a canal extended up this street nearly to the corner. This is the best example of a New York Street under Three Flags-Dutch, English and American. 


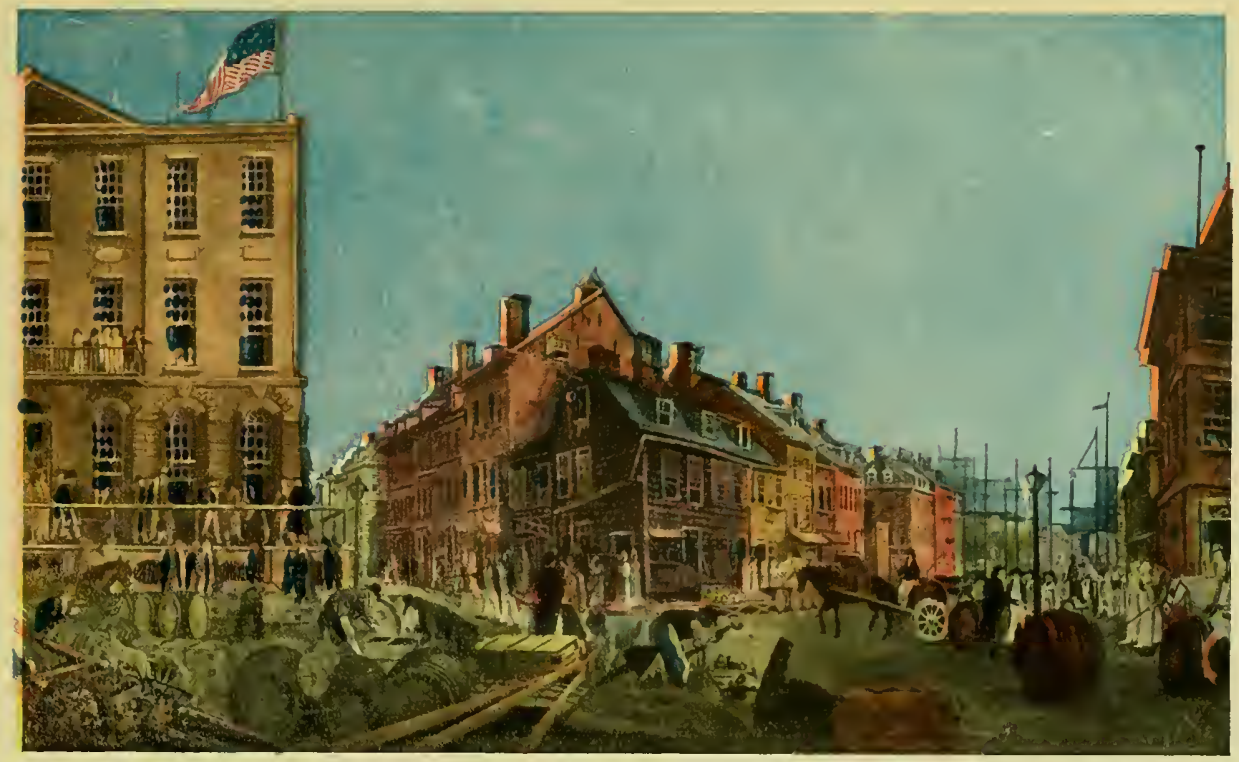

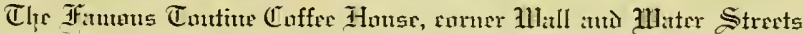

This coffee house, the building on the left, played a prominent part in the development of the financial district. From it sprang the Merchants' Exchange and it was the forerunner of all the other Exchanges. It succeeded the Merchants' Coffee House, perhaps the most famous tavern New York ever possessed.

From the only known painting by Francis Guy $(\mathbf{I} 706)$ in porsession of the New York Historical Saciety

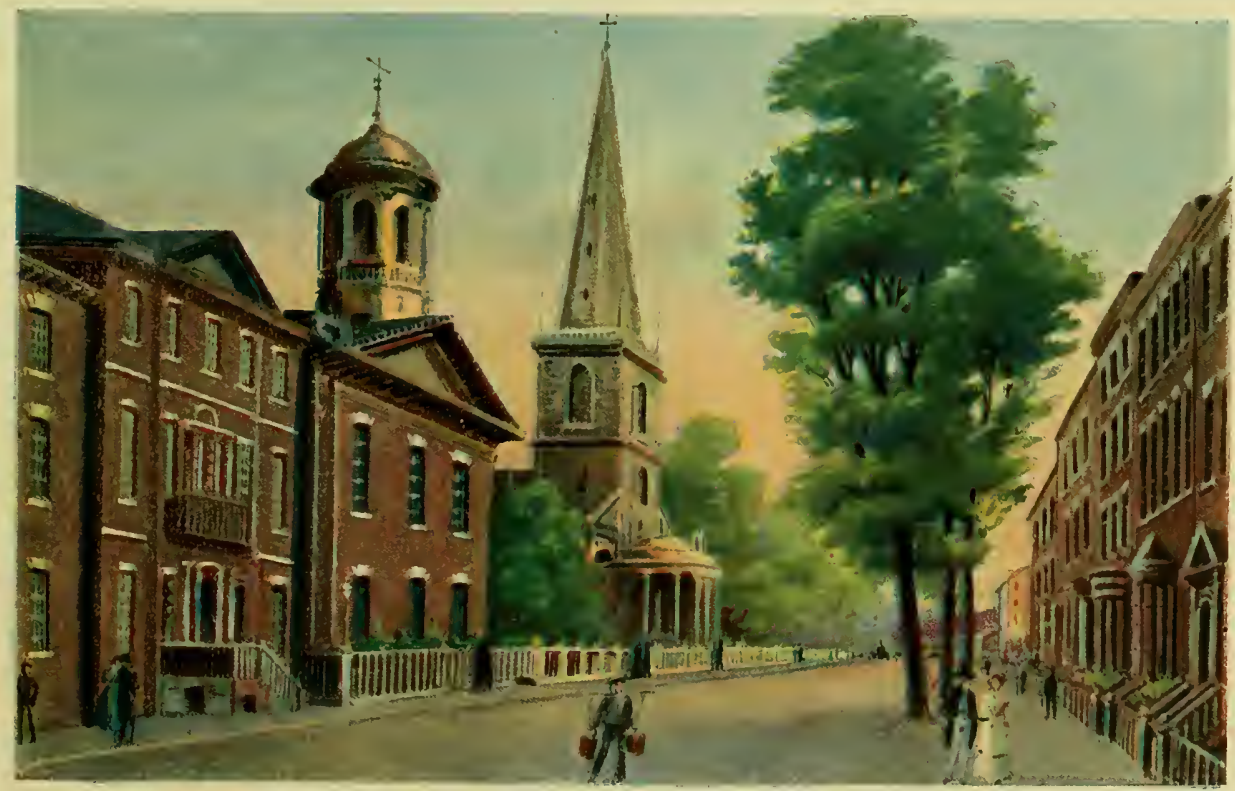

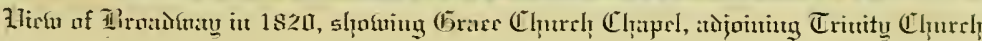

A most interesting and contemporaneous view of Broadway while it was still a fashionable residential section. Grace Church moved uptown to Tenth Street fifteen or twenty years later. The Empire building, 71 Broadway, headquarters of the United States Steel Corporation, occupies the Grace Chapel site today, and both sides are lined with huge skyscrapers. 


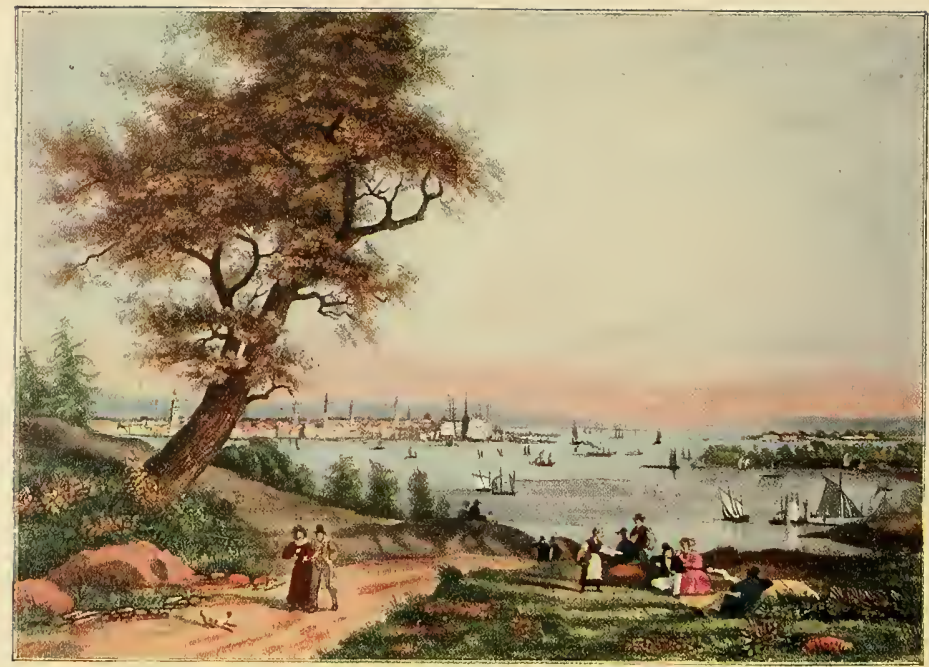

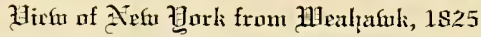

Taken from near the site of the Hamilton-Burr duel. This picturesque region is now wholly covered by huge coal pockets, railroad terminals, army docks and foreign steamship piers. Above the cliffs to which the road leads, lies a very pretty suburban city connected with New York by ferry.

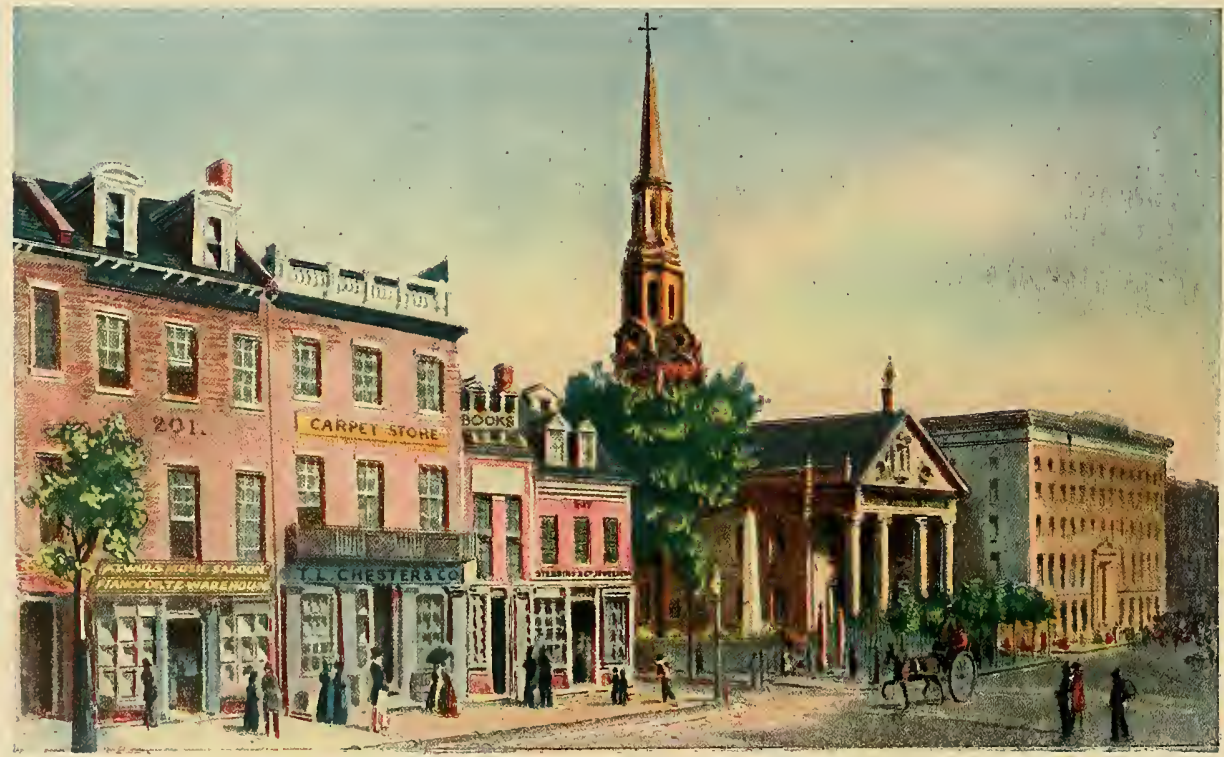

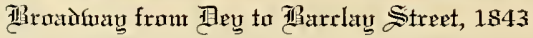

Rare drawing of Broadway, showing St. Paul's and the Park View Hotel (Astor House) about 1843. The small two-story houses at the left are part of the block between Fulton and Dey Streets now covered by the new buildings of the American Telephone and Telegraph Company. 


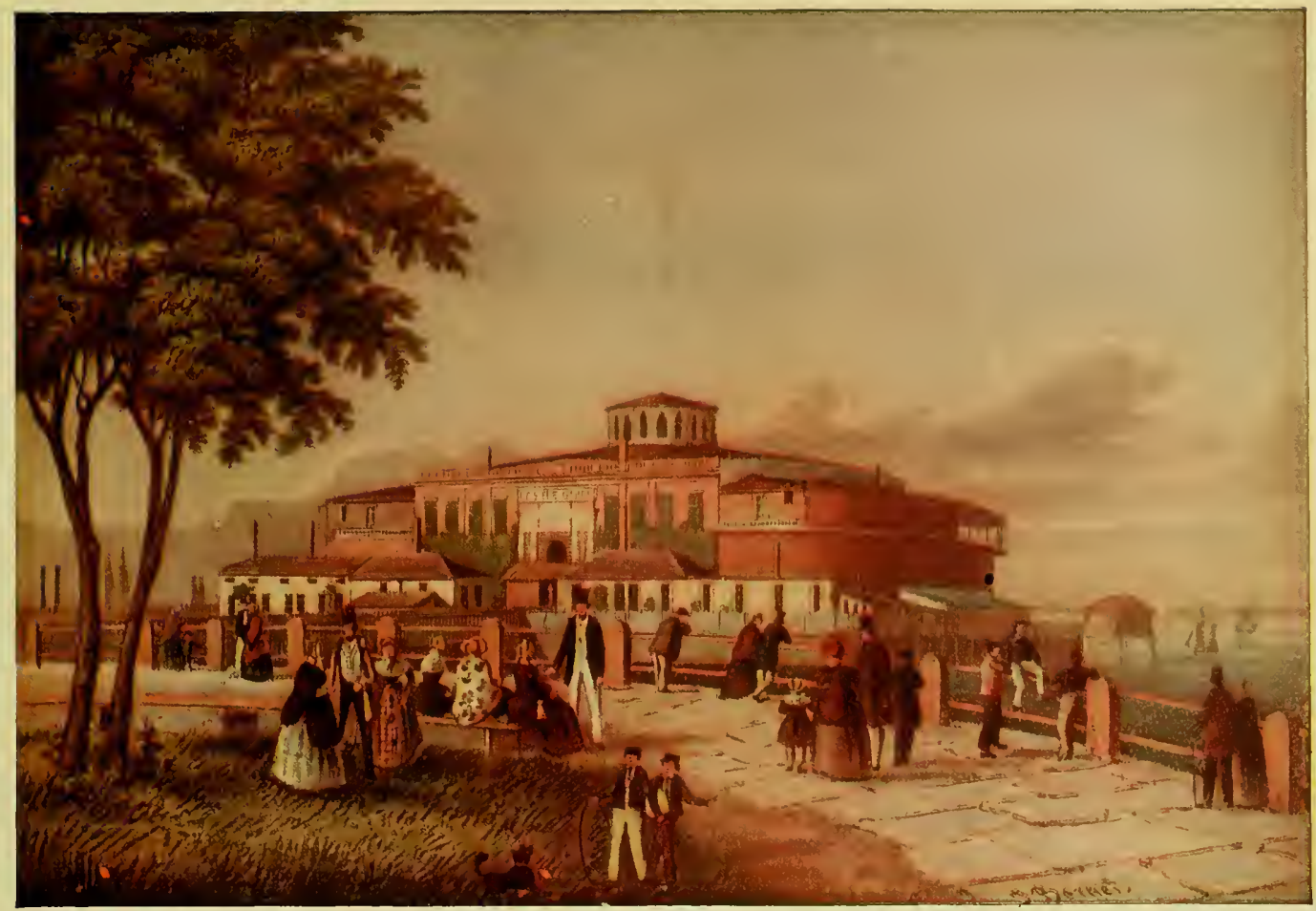

Uastle (6)aritu in 1850

This is now our Aquarium. It was originally built as one of the main defences in the War of 1812 and was named Fort Clinton. It was originally separated from the mainland by a stretch of water which was filled in prior to 1850 . After the peace, it became a great popular place of amusement and was the scene of Jenny Lind's first appearance in America under the great P. T. Barnum. It then became the receiving station for emigrants, many of whom settled in the West and elsewhere, and still remember old Castle Garden. The present Aquarium, daily open to the public, is one of the most interesting features of modern New York. Courtesy Doun Tosen Association

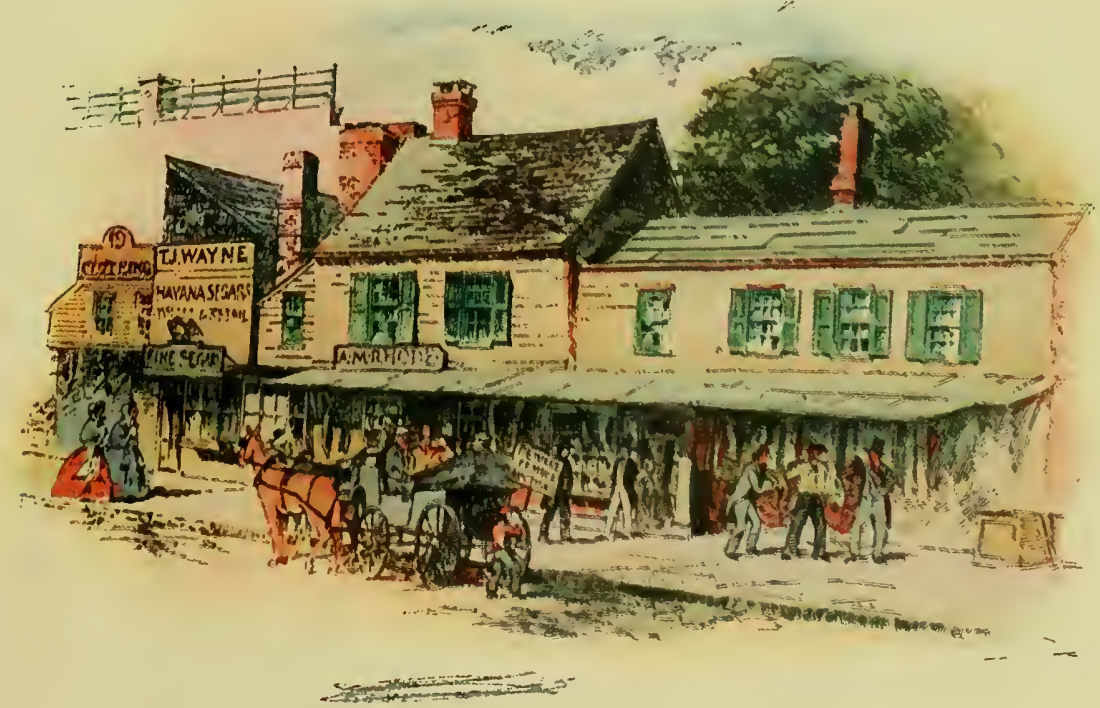

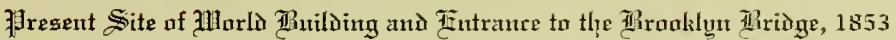

Nothing shows the great changes in New York better than the substitution of the great East River Bridge entrance and the World Building for these wooden shacks that stood opposite City Hall Park in the 50's. This is Park Row, popularly known as Newspaper Row, where many of New York's grea dailies were published. Only the World and the New York Tribune remain on this block. The great Municipal Building leading to the new Civic Centre is across the way. 


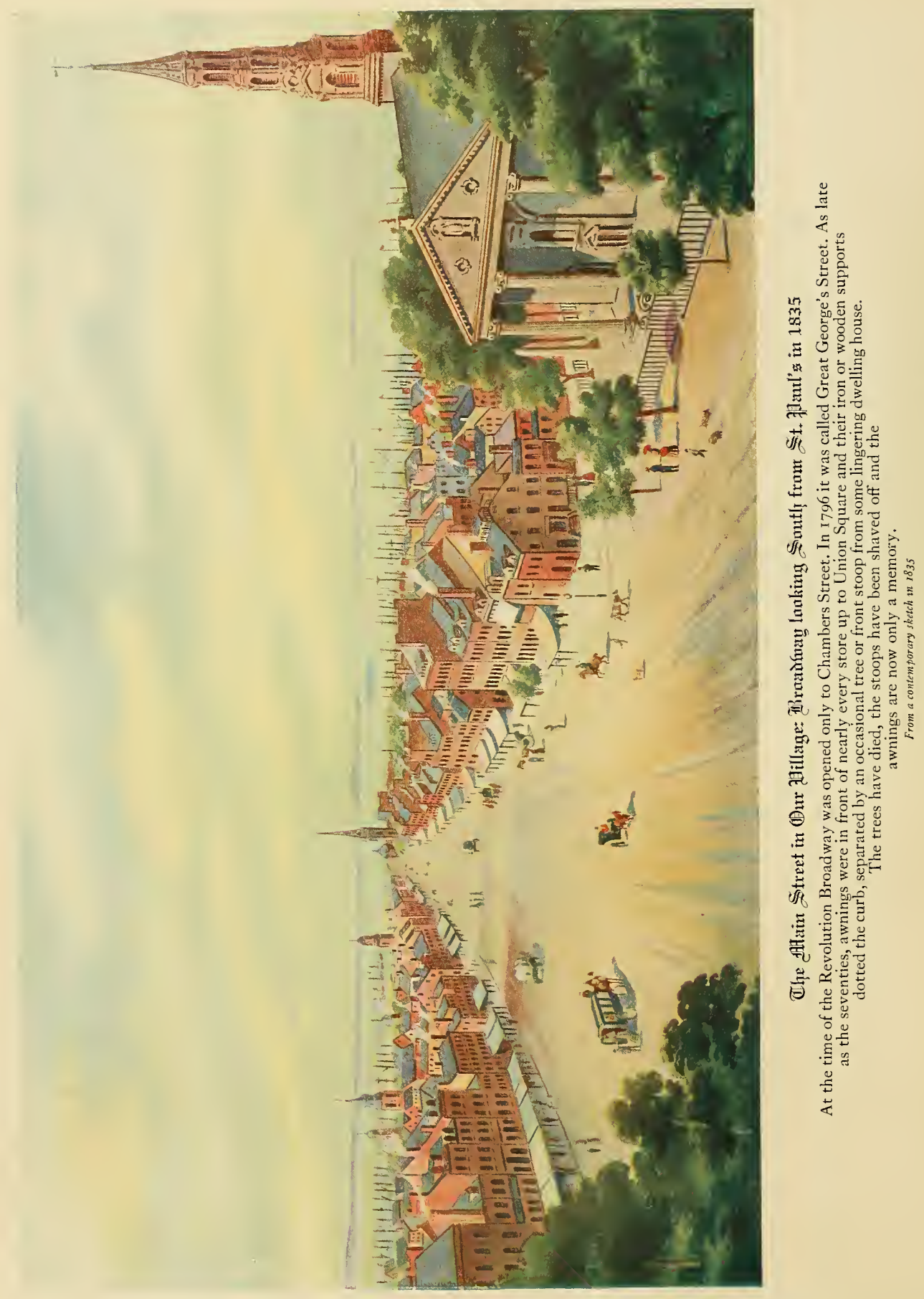




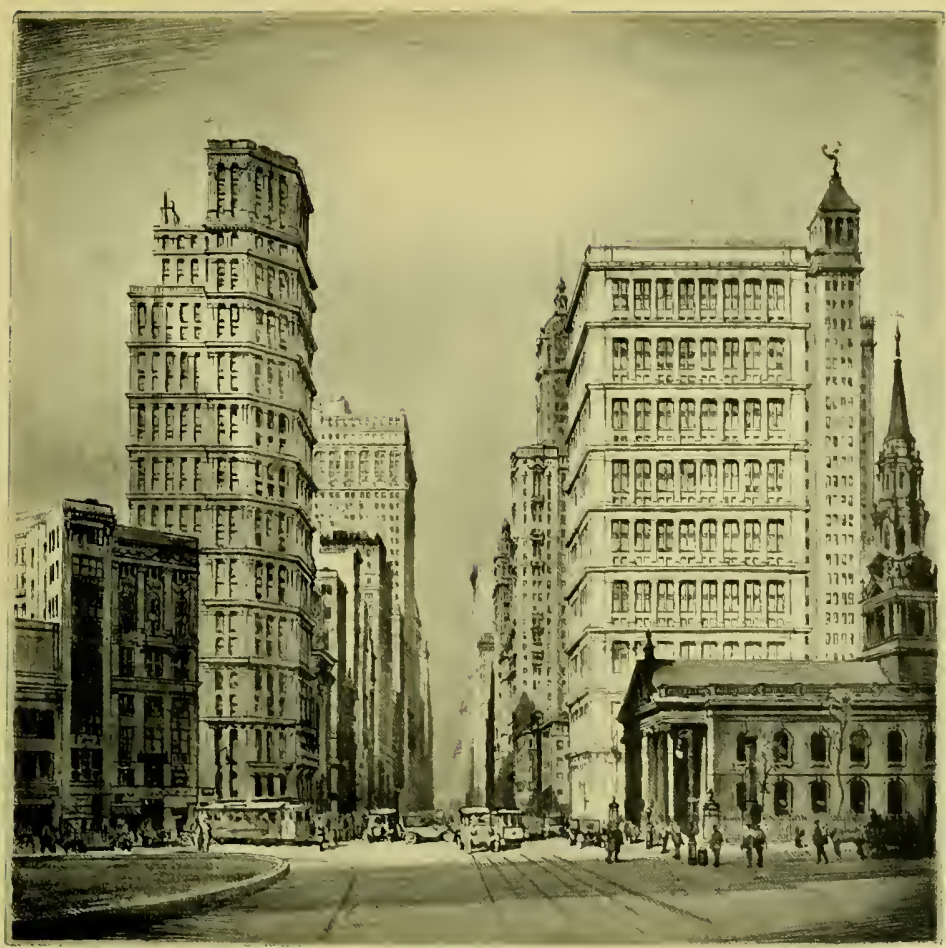

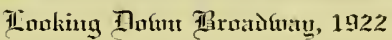

(c) A. B. A.

Broadway at St. Paul's Church from same point as shown on opposite page. St. Paul's is at the right in each picture.

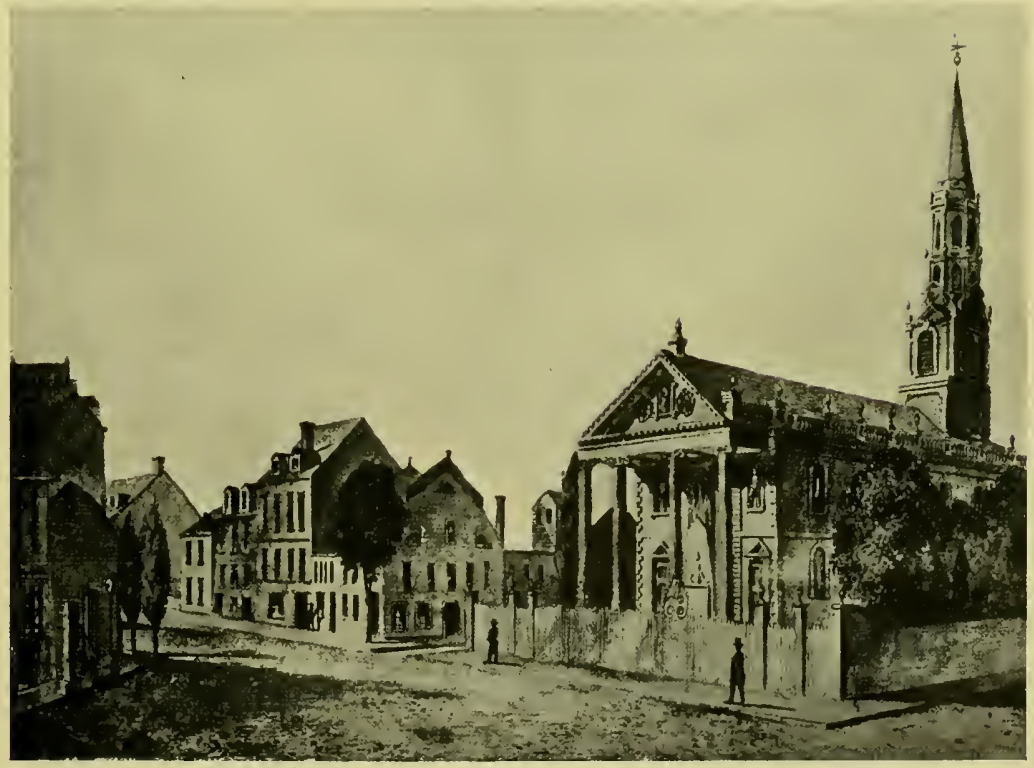

Collection of New York Hustorical Society

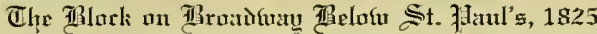

This gives an excellent idea of the great change in this locality in less than a hundred years. The magnificent new Telephone Building shown at right in the picture above, now covers the entire block between Fulton and Dey Streets. The contrast in the architecture of the two periods is impressive.

From a contemporary drawing by Strickland 1 $\$ 25$. Now in collection of New York Historical Society. 


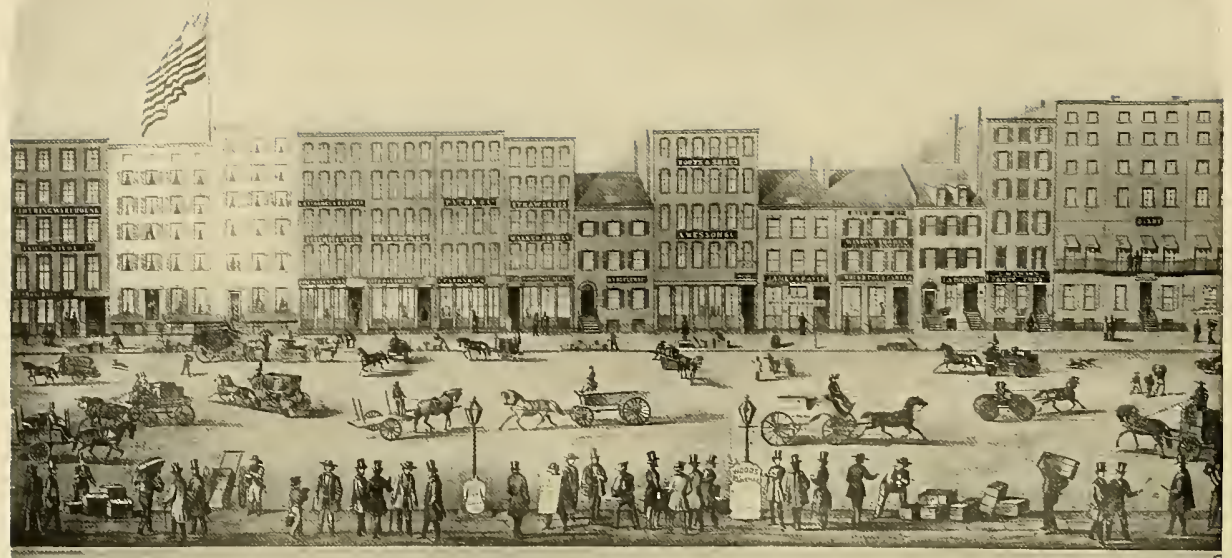

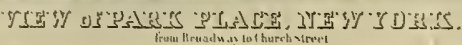

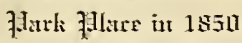

North side from Broadway to Church Street. This was at one time $(1830)$ a beautiful secluded private residential street which ended at Columbia College grounds.

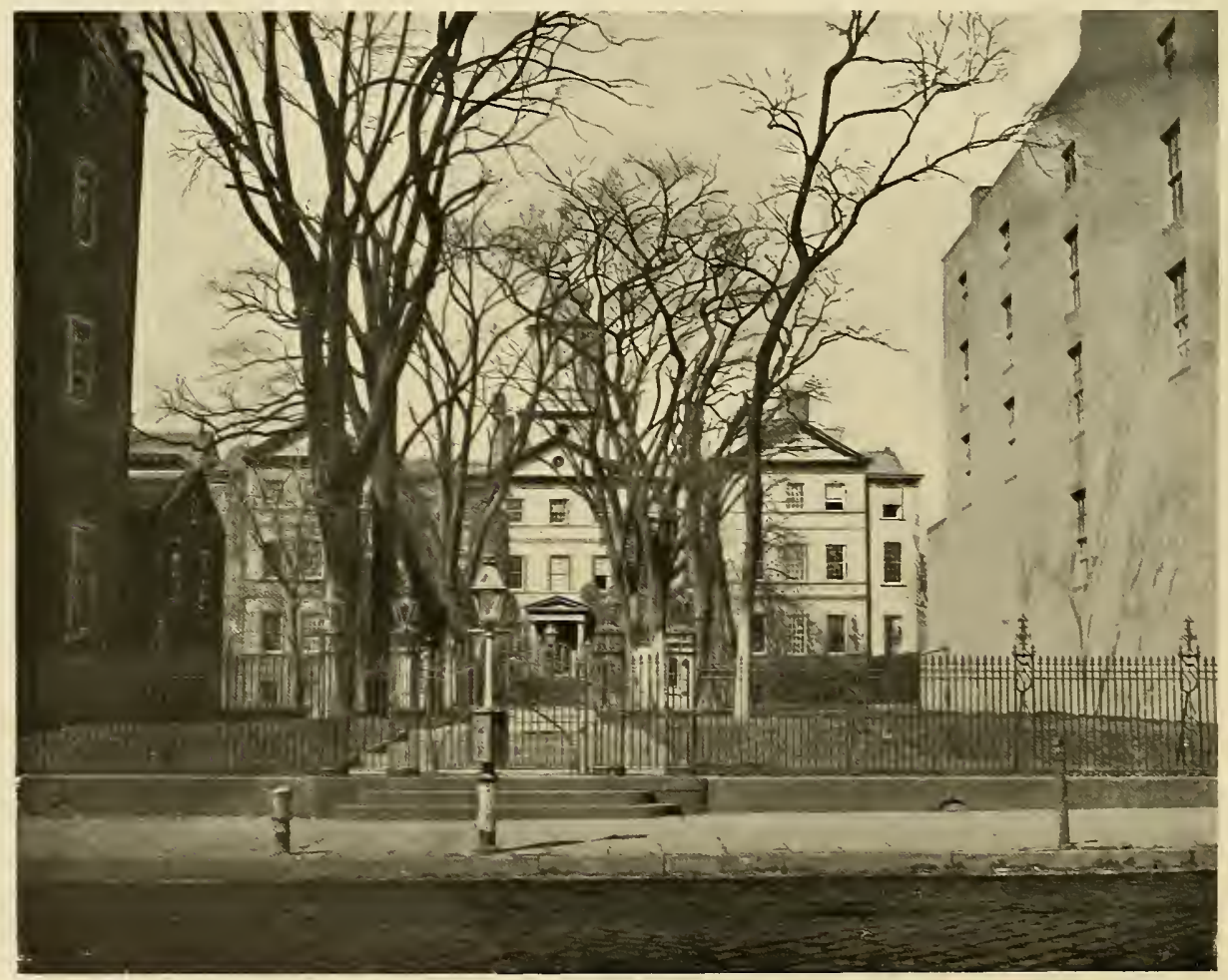

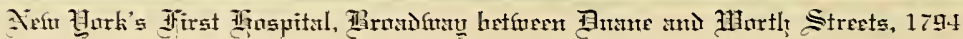

This was from a photograph taken about 1868 , just before the building was demolished. Washington Irving was one of its early Trustees. It is now on West 15 th Street. 


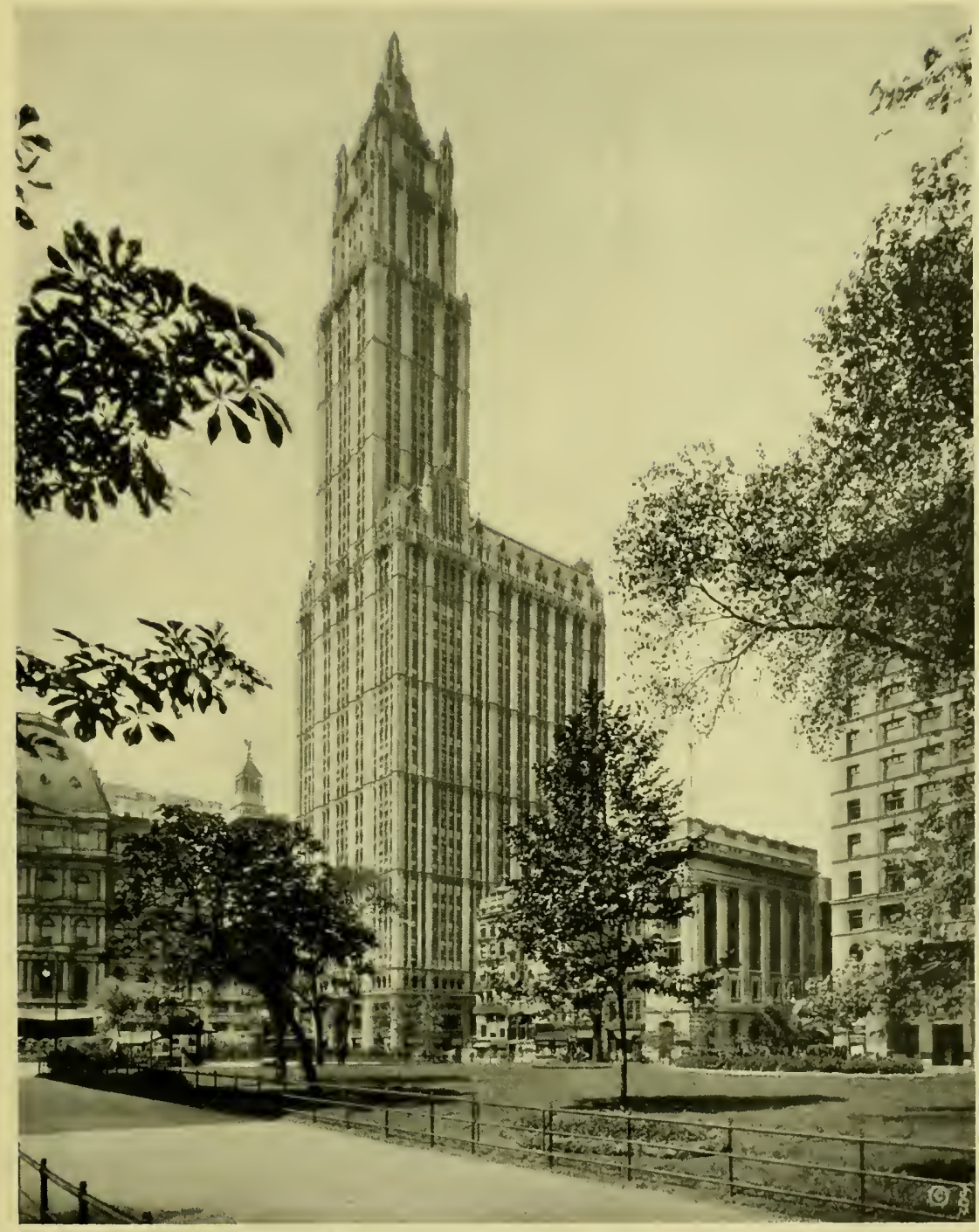

The Mllnolfuortl! IIhtiling

Broadway, between Purk Place and Vesey Street; conceded to be the most beautiful business building in the world. A constant reminder of the value of little things, and a monument to the memory of Frank Winfield W'oolworth, founder of the now famous "Five-and-Ten" stores.

On this Woolworth site, formerly stood some prominent private dwellings. Philip Hone, author of the famous Diary bearing his name, fived in this end house at the right while Mayor of the City in 1825 .

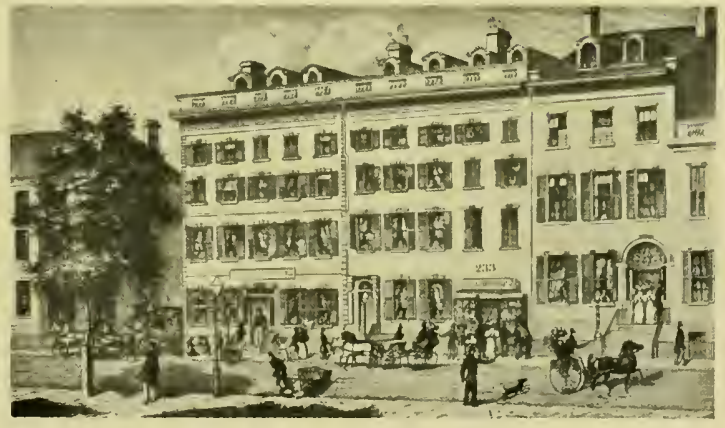




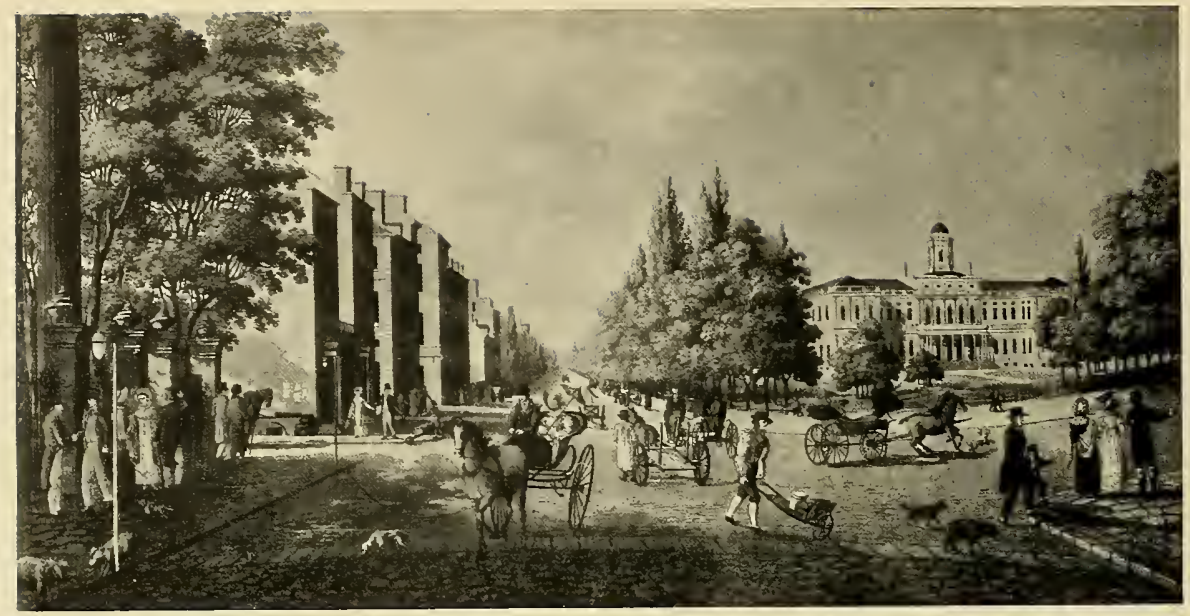

Collection of Mr. Percy Pyne II.

Tlipe Alpproarli to Clitg Thall in 1825

St. Paul's Church at extreme left, City Hall on the right, Broadwav and private houses on left. The ubiquitous pig, at one time virtually our Street Cleaning Department, is a feature of many early New York pictures.

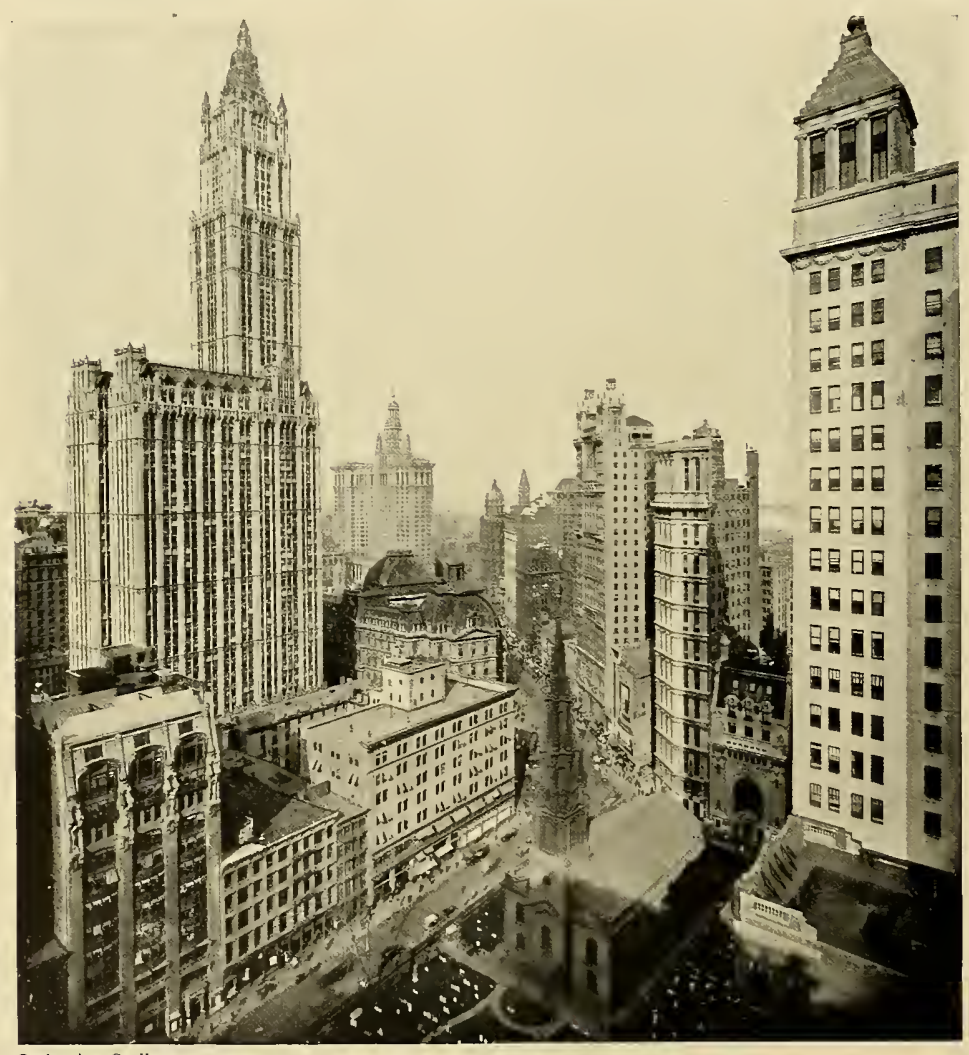

(C) American Studios

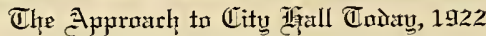

The same section in 1922 . The low six-story building in the center is part of the site of the Astor House. The prominent modern buildings include the Woolworth at the left, the Municipal Building in the distance, centre. To the right of this is "Newspaper Row" with the World and Tribune Towers, and in the right foreground, the American Telephone and Telegraph Building. 


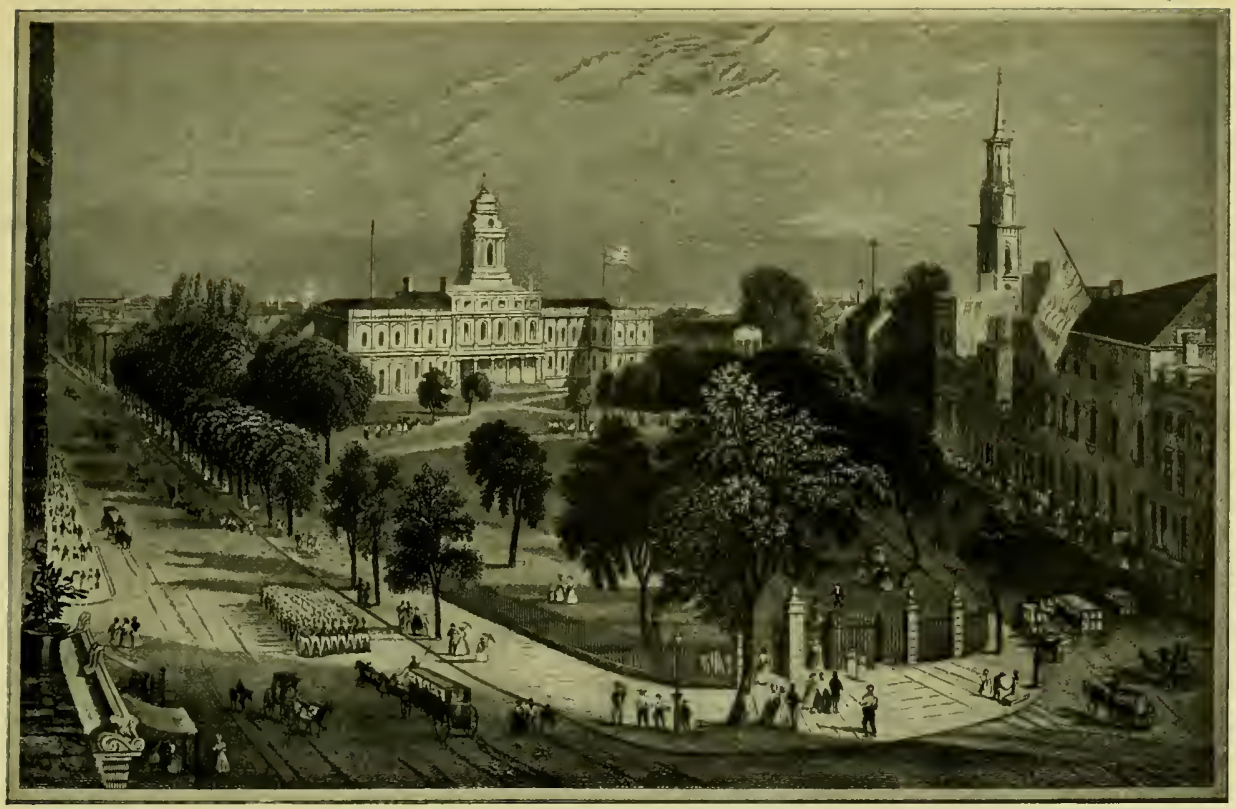

Copyright, 1913. H. C. Brown

The $\mathbb{C}_{\text {ity }}$ Illall Flark as it Apprared alount 1830

The present Post Office which spoils its appearance and greatly reduces its size will soon be removed.

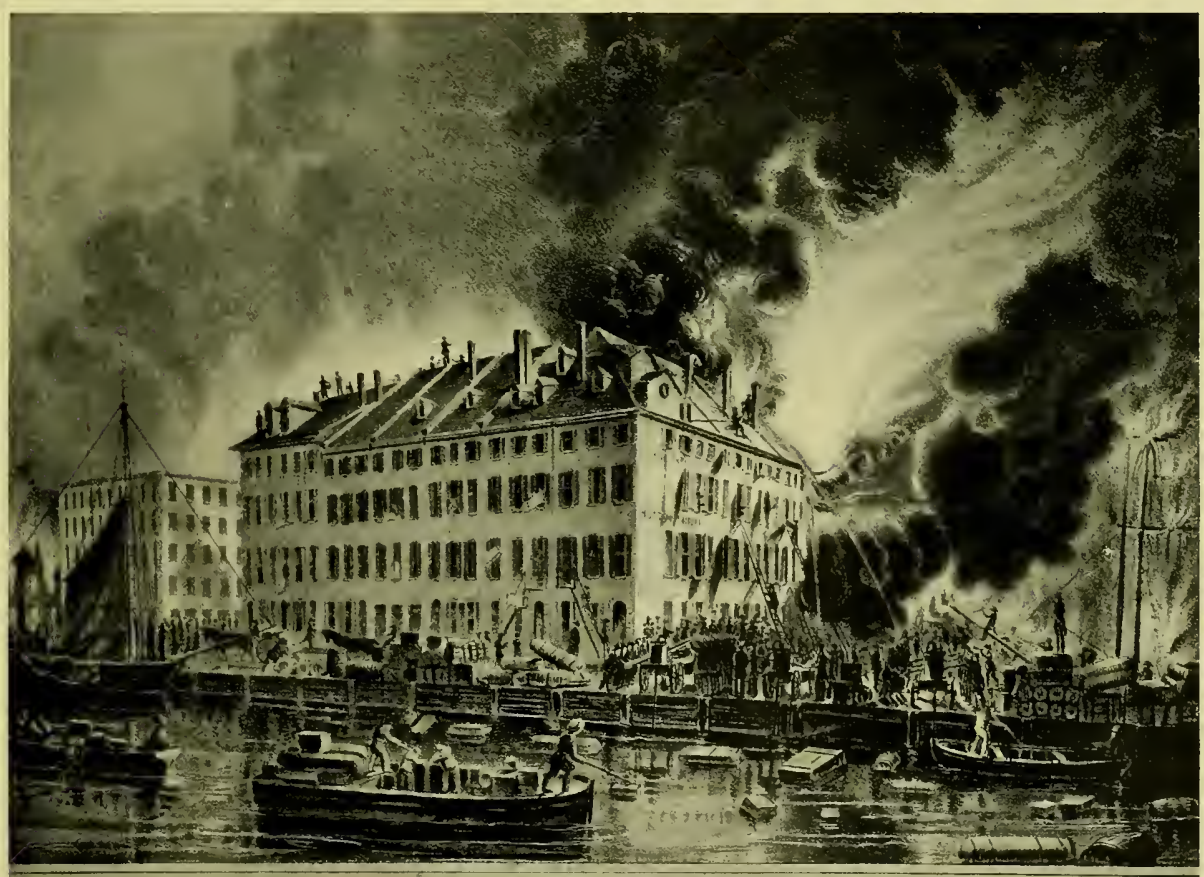

VIEW OF THE GREAT CONFLAGRATION OF OES $16^{\text {"MAO }} 17$ "1835. FROM COENTIES SLIP. 


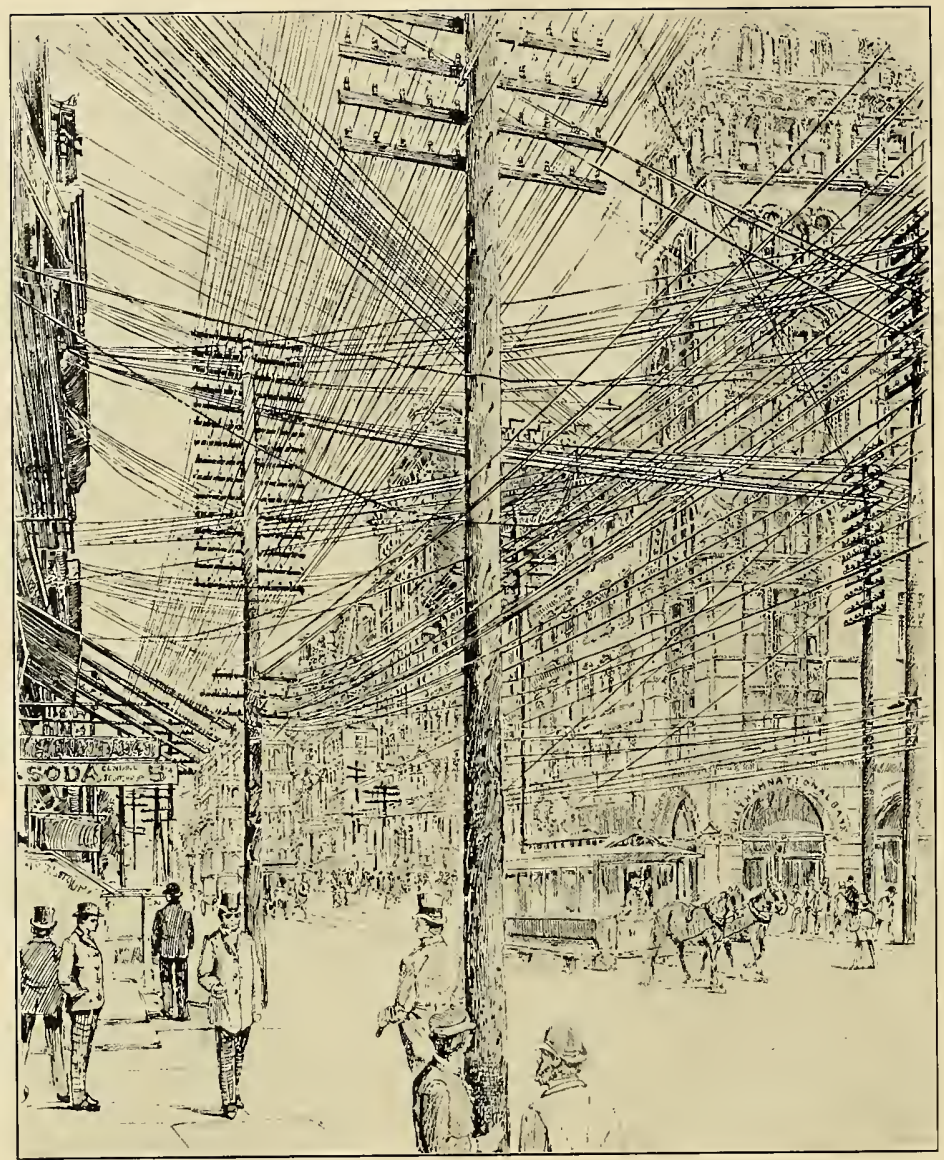

New York Historical Society

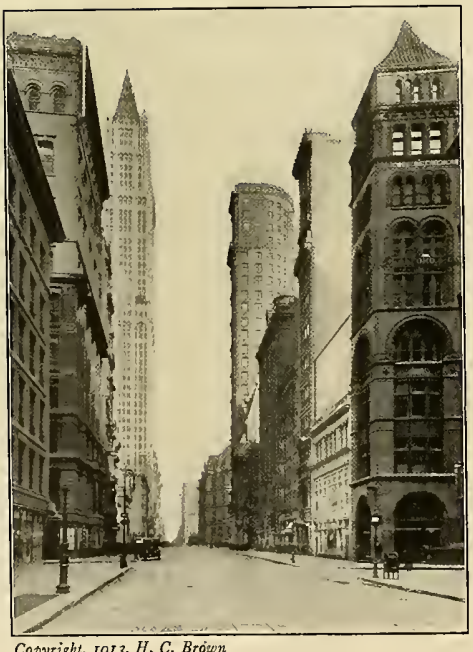

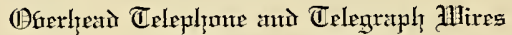
in 7 ronaturnau, 1890

A view of the corner of Broadway and John Street in the early days of the telephone, when the wires were added to the already overburdened poles. The picture at the left, taken from the same corner, shows the vast imptovement when all wires were put underground. 


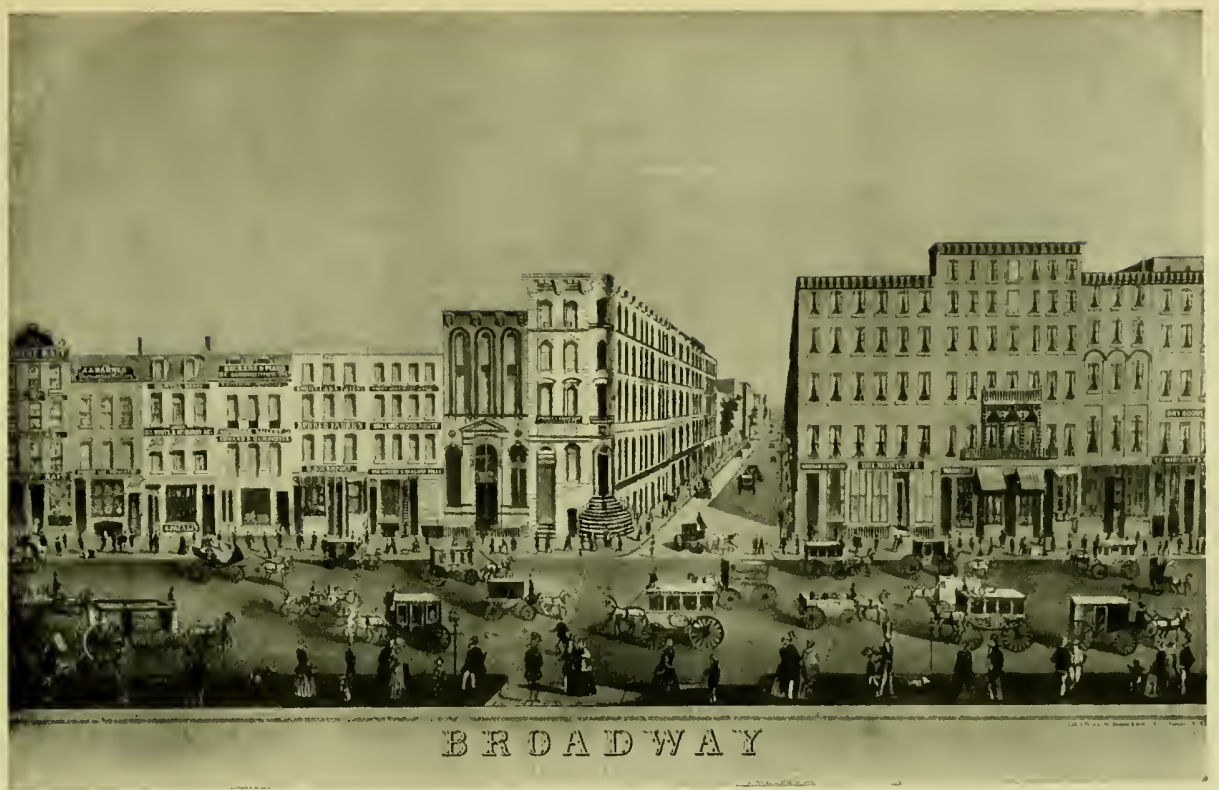

Collection of the Chemical Bank

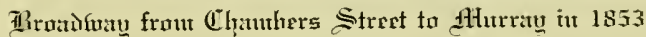

The old Shoe and Leather Bank occupied the left comer of Chambers Street (centre). Delmonico's Restaurant adjoined the Irving House on the right. Note the curious costumes and vehicles in foreground.

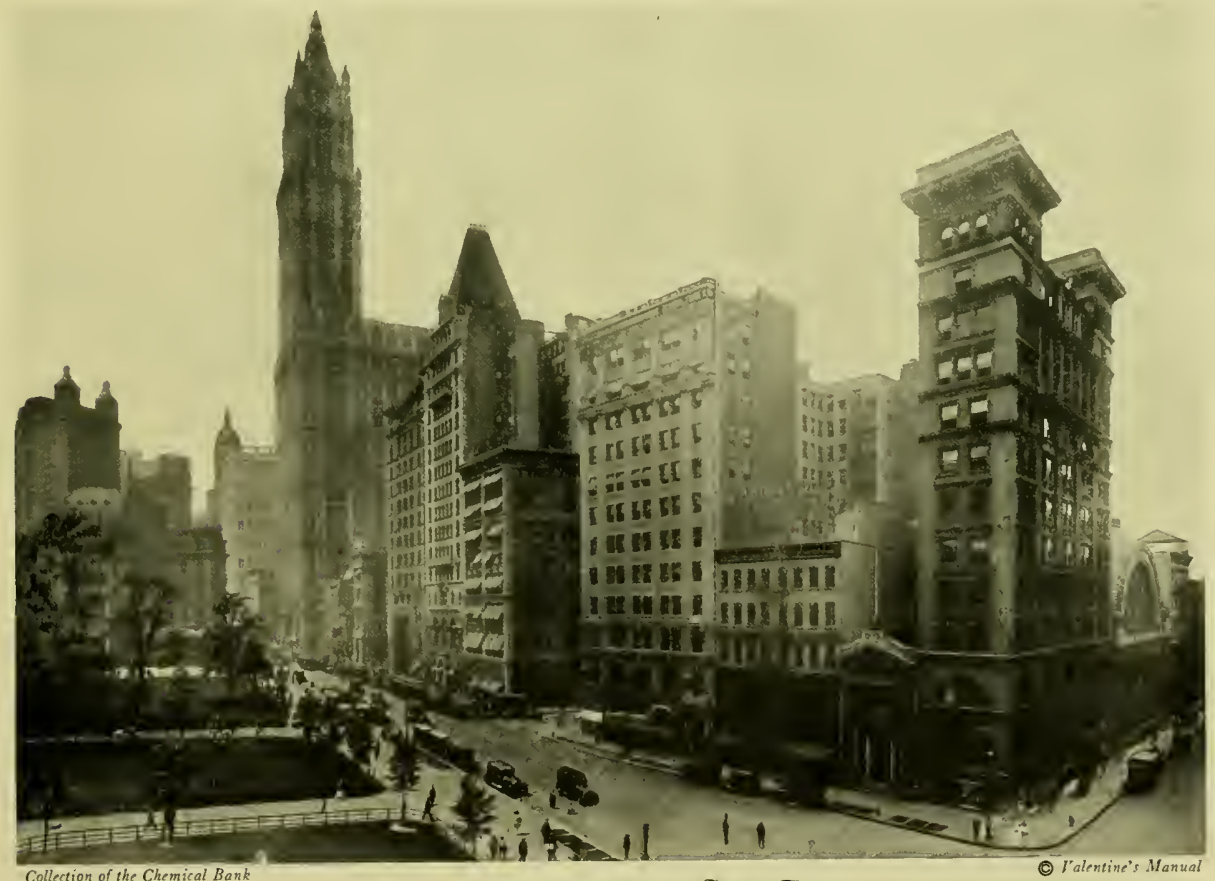

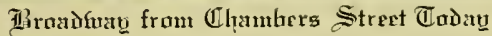

Showing the great Chemical Bank at extreme right; the Importers and Traders at Murray Street; and the Postal Telegraph Building in centre, corresponding to the buildings in the picture above. 


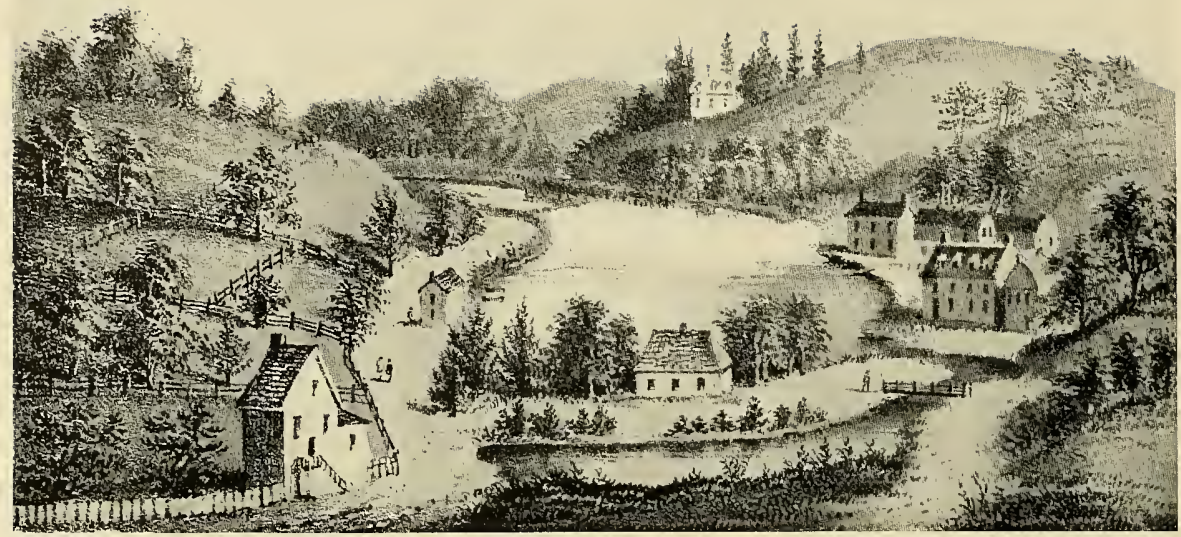

Valentine's Manual

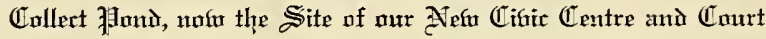

One of the most famous sections in Old New York. The water was very deep and covered seventy acres. At one time it was proposed to make it a huge land-locked harbor for deep sea vessels. A canal was started through Canal Street (hence the name) to connect it with the Hudson. It was a famous resort for fishermen and skaters. Prince William, later William IV of England, was saved from drowning here. Fitch tried out his new steamboat on this lake. It was finally drained and filled in about $\mathrm{I} 82 \mathrm{I}$. Then the old "Tombs" was partly built upon it. Now all the land has been taken by the City for the new County Court House, Federal Post Office and other buildings for our new Civic Centre. See next page.

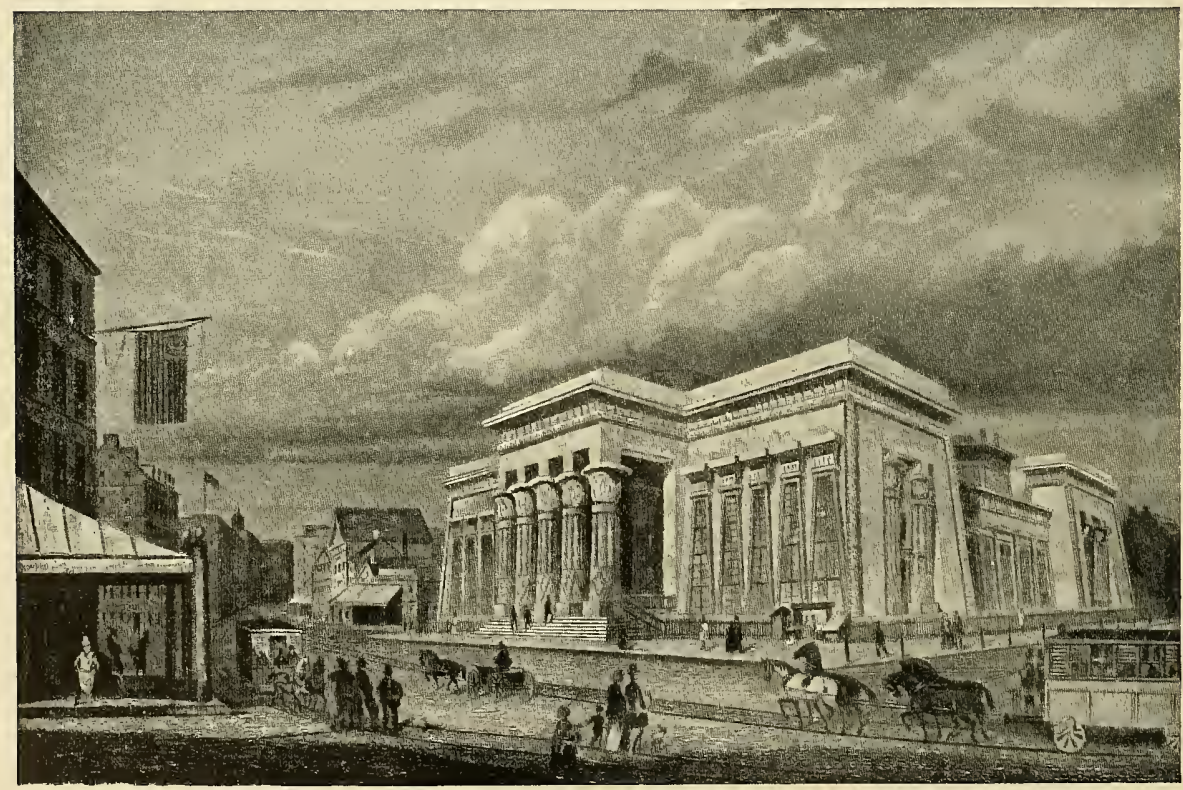

Collection of Mr. J. Clarence Davies

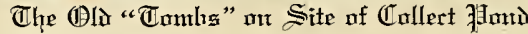

The old City Jail, called "The Tombs," and Criminal Courts Building, on Centre Street, between White and Leonard (built in 1838 from stone taken from the Bridewell in City Hall Park), which were removed to make room for the present Magistrates Courts and jail. The bridge which joined them gave convicted persons their last look of freedom, and was known as the "Bridge of Sighs."

The site was formerly covered by Collect Pond, shown above. 


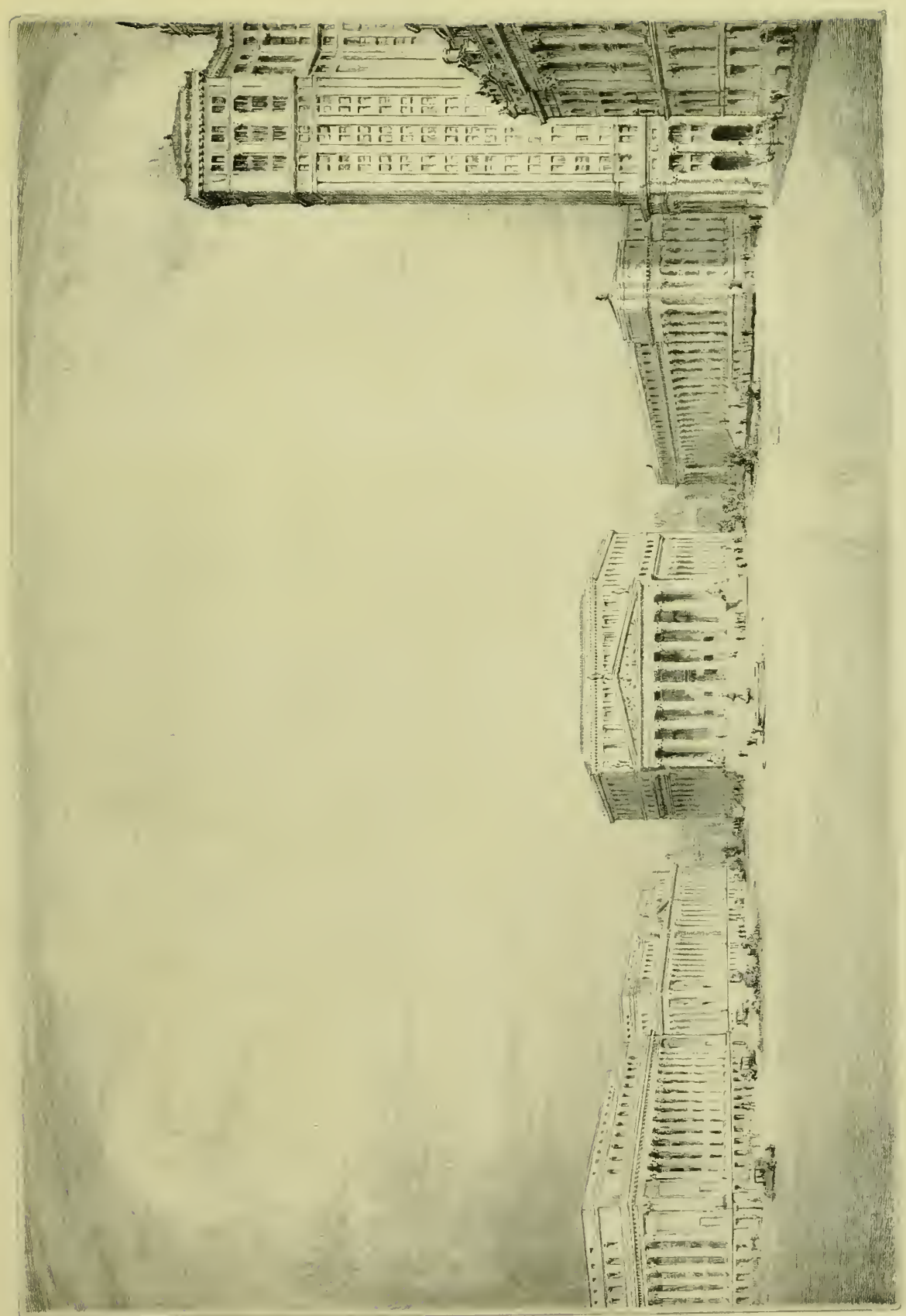




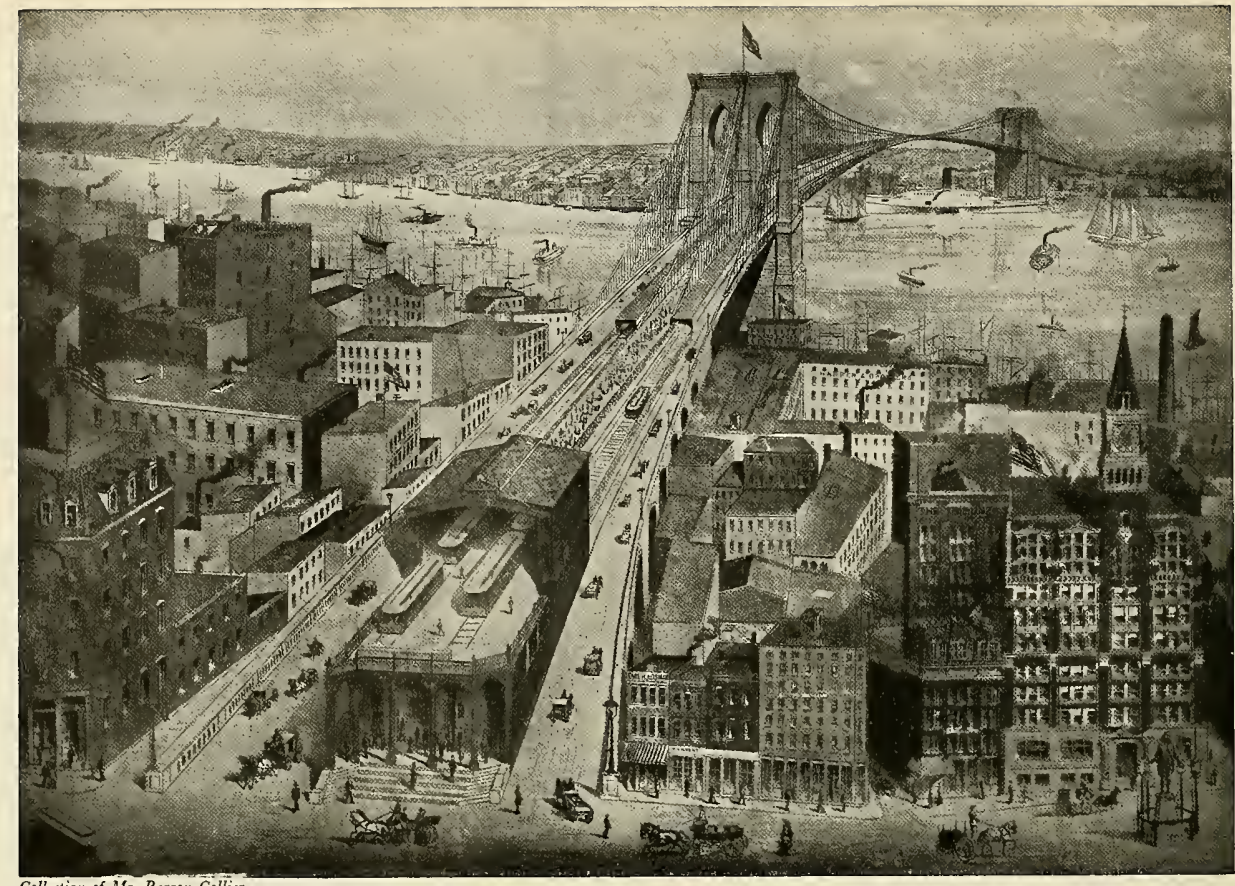

Collection of Mr. Barron Collier

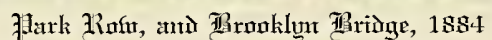

Approach to Brooklyn Bridge as it appeared when first opened. The row of small buildings on right facing Park Row, including French's Hotel, a famous hostelry, are now occupied by the World Building. The old Sun Building and Tribune Building are at extreme right.

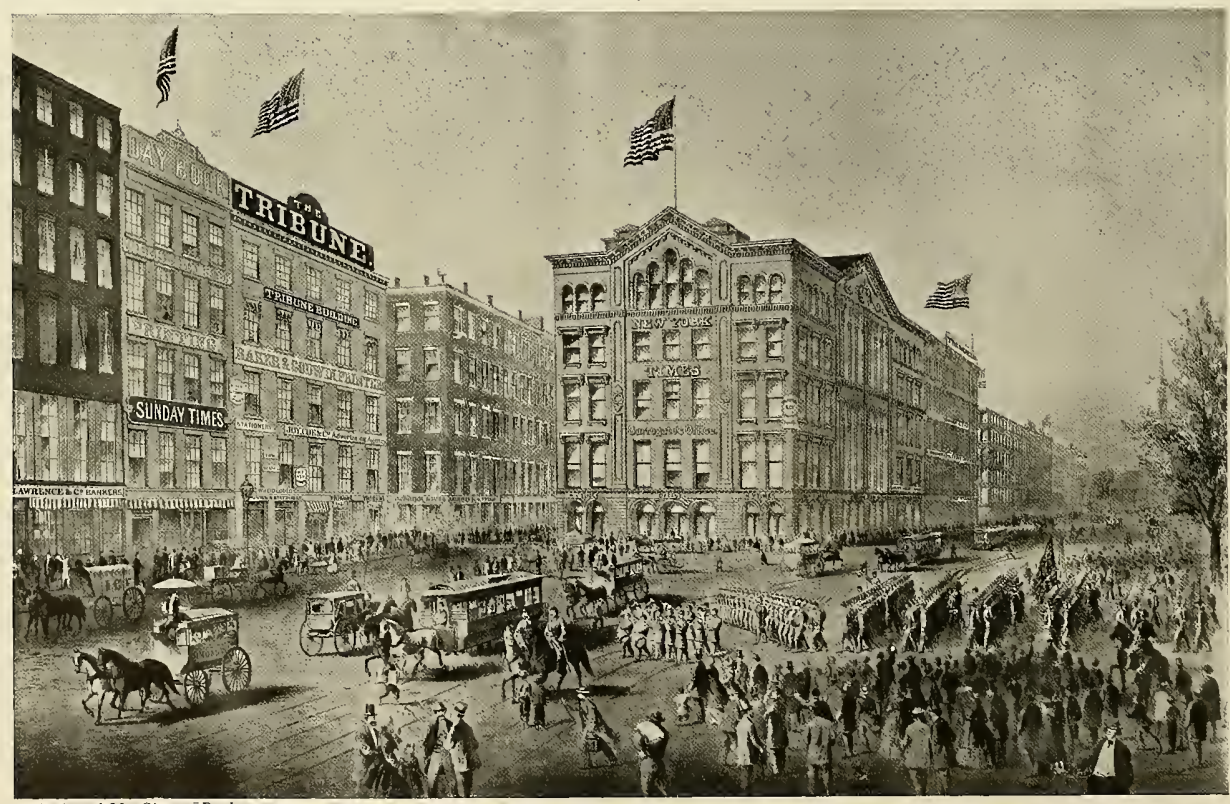

Collection of Mr. Simeon-Ford

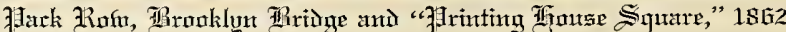

Here is an excellent view of "Printing House Square" in the days of Greeley, Dana, Raymond and Jones. The Post Office was not yet built and the view to St. Paul's Church was unobstructed. This picture wag taken in I 862 , when troops were leaving every day for the war. Most of the newspapers have now moved uptown. 


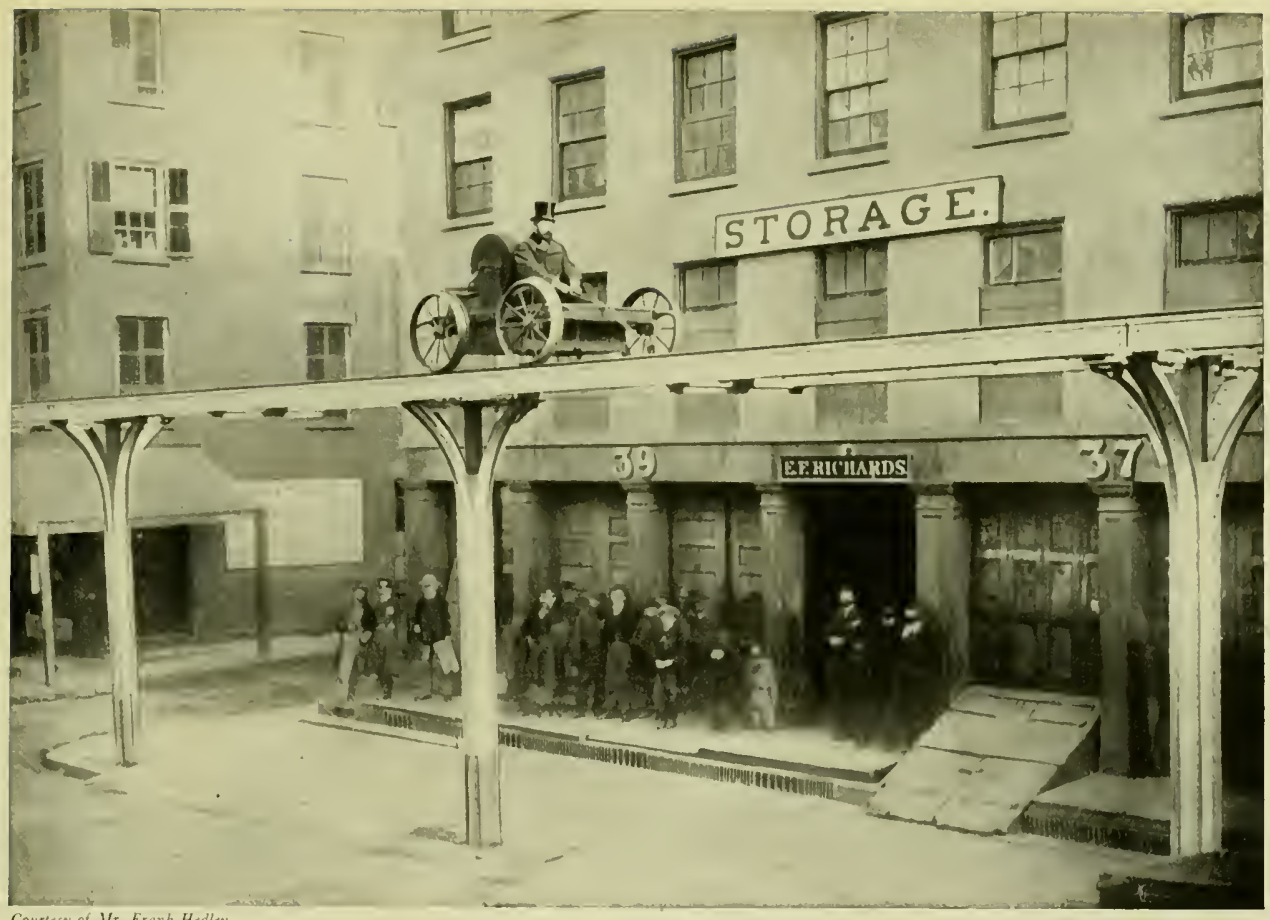

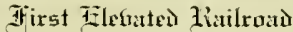

Charles T. Harvey, President of the first Elevated Railroad, the West Side $\mathbf{X}$ Yonkers Patented R. R. (now Ninth Avenne), demonstrating that a car would not fall off the track, 1868. Mr. Gerehardt, third from the right, is still actively employed in the Interborough Company. Yonkers men are entitled to the credit of the first attempt at rapid transit in New York.

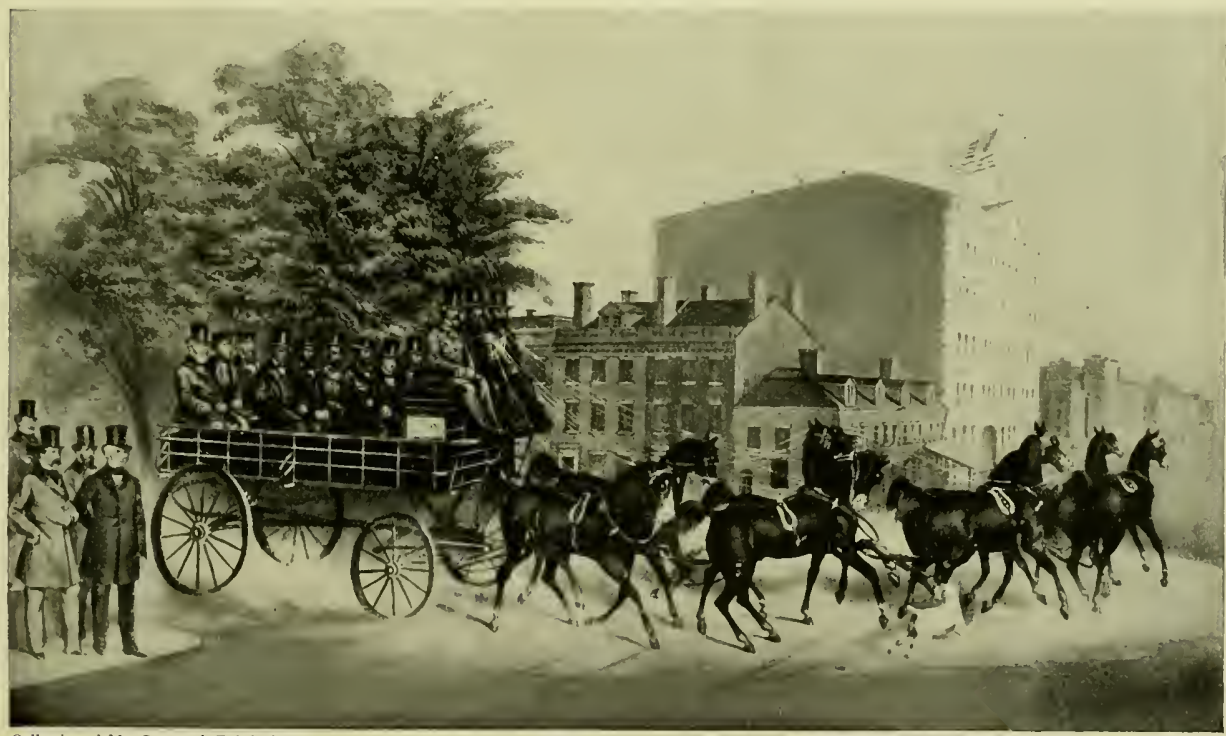

Collection of Mr. Gearge A. Zabriskie.

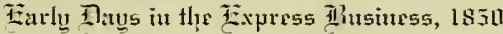

Officers and directors of the American Express Company at the corner of West Broadway and Reade Street, on one of their red and green wagons, on the way to the dedication of their new Hudson Street Building, shown in the background. About 1853 . Each face was a portrait taken for this occasion and deftly inserted in the drawing-apparently a popular custom in those days.

(See also Seventh Regiment picture, Washington Square) 


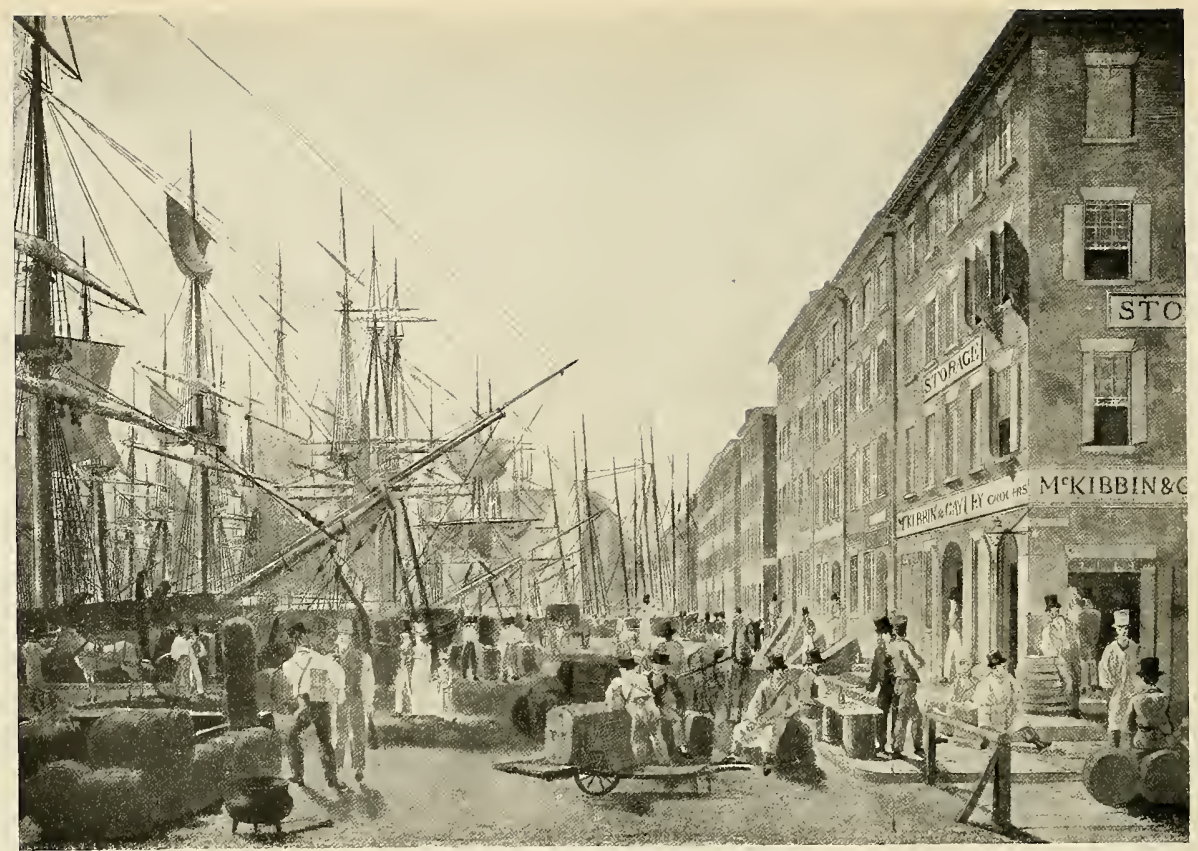

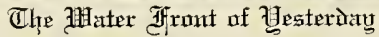

South Street in the "Roaring Forties," showing the spars and bowsprits of the China Tea Clippers; the Californian, Australian and Liverpool Packets and square-rigged beauties from every port in the world.

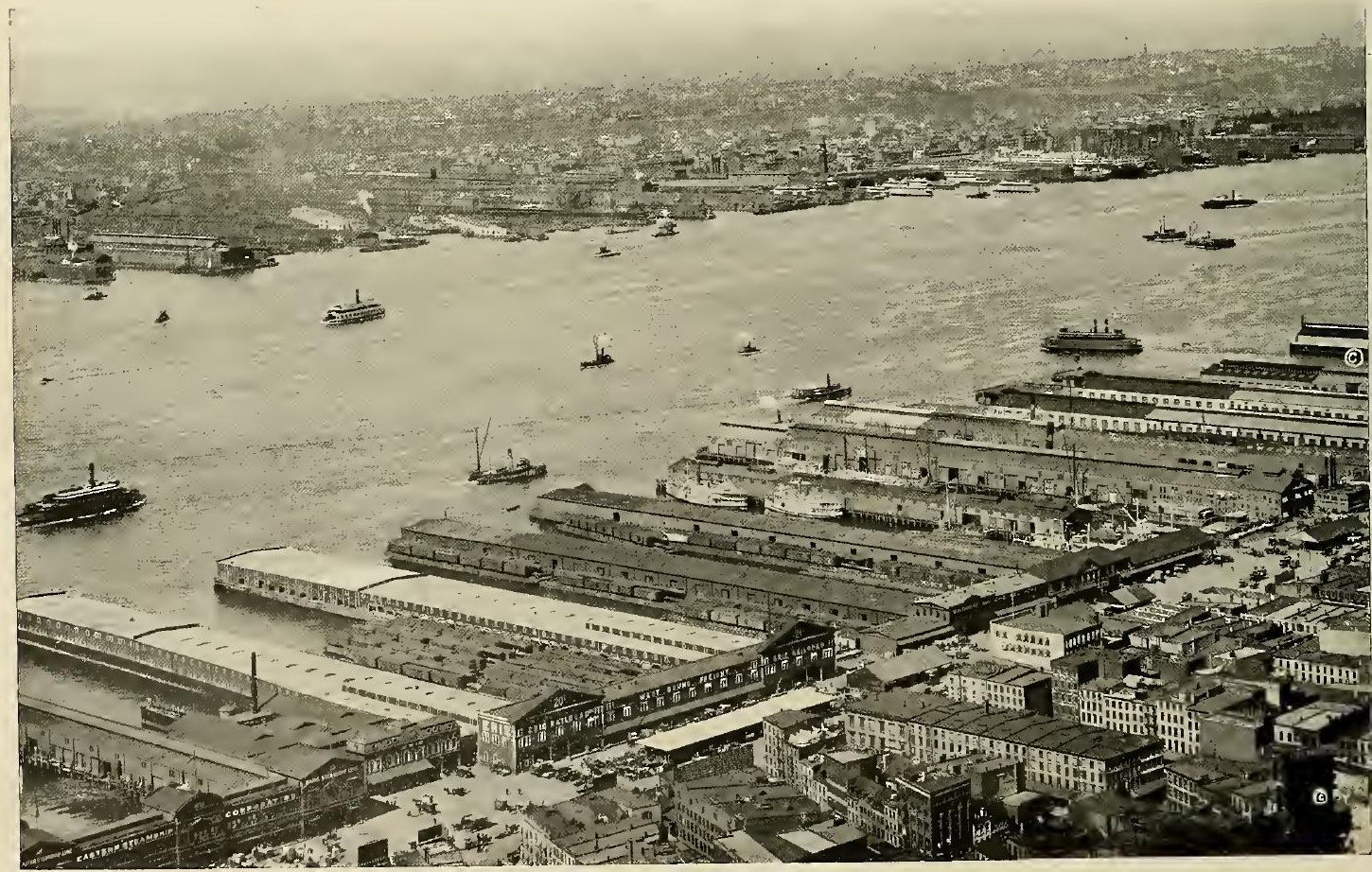

The Zllater Tront of Thàn

The advancing power of steam has all but driven the picturesque sailing ship from the highways of the sea. Through these prosaı looking portals, passes most of the foreign commerce of our city. The Chelsea Docks at Twenty-Third Street, owned by the city, are over a thousand feet long and built of concrete. North of Twenty-Third Street are other docks in course of construction by the Municipality, surpassing anything yet accomplished, both in size and equipment. 


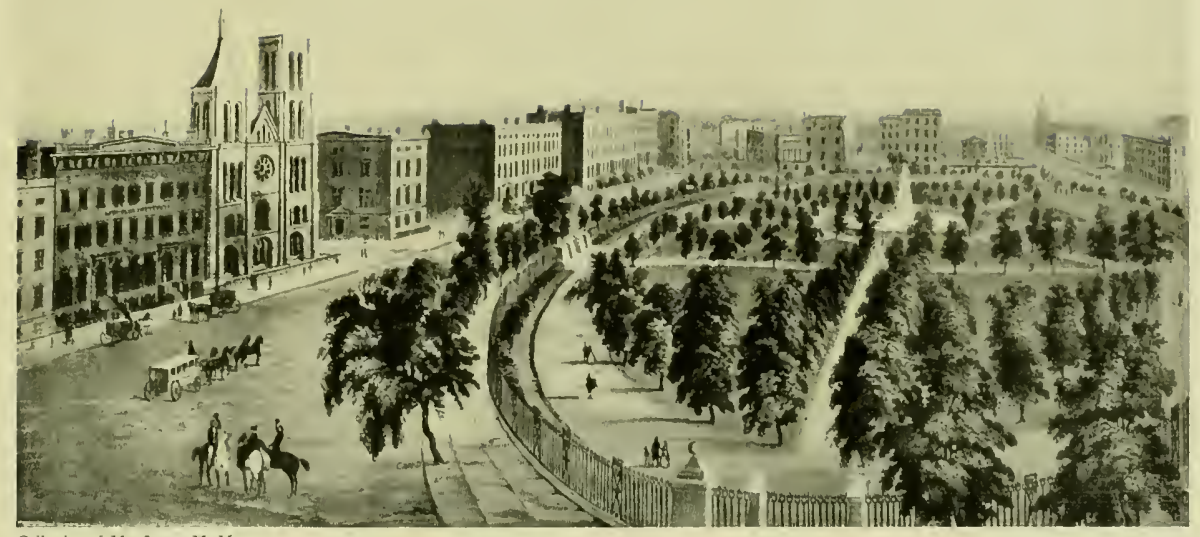

Collection of Mr. James M. Montgomery

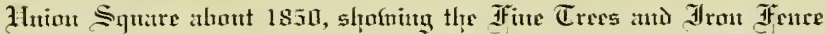

The Church of the Puritans is on the left, and adjoining, Abbott's Collegiate Institution for Girls, a famous young ladies seminary, and Daniel Drew's residence above it on the corner of i6th Street.

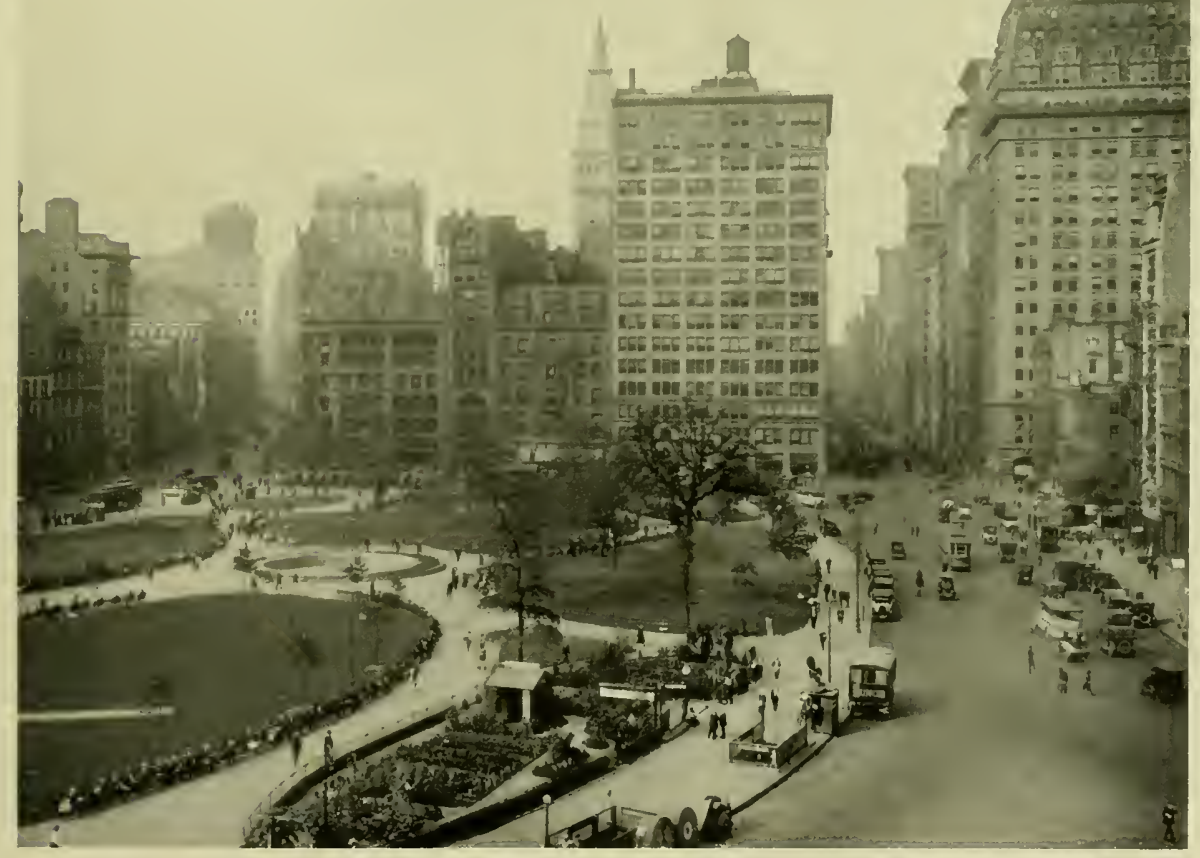

Thye Sume Squure Toùy 


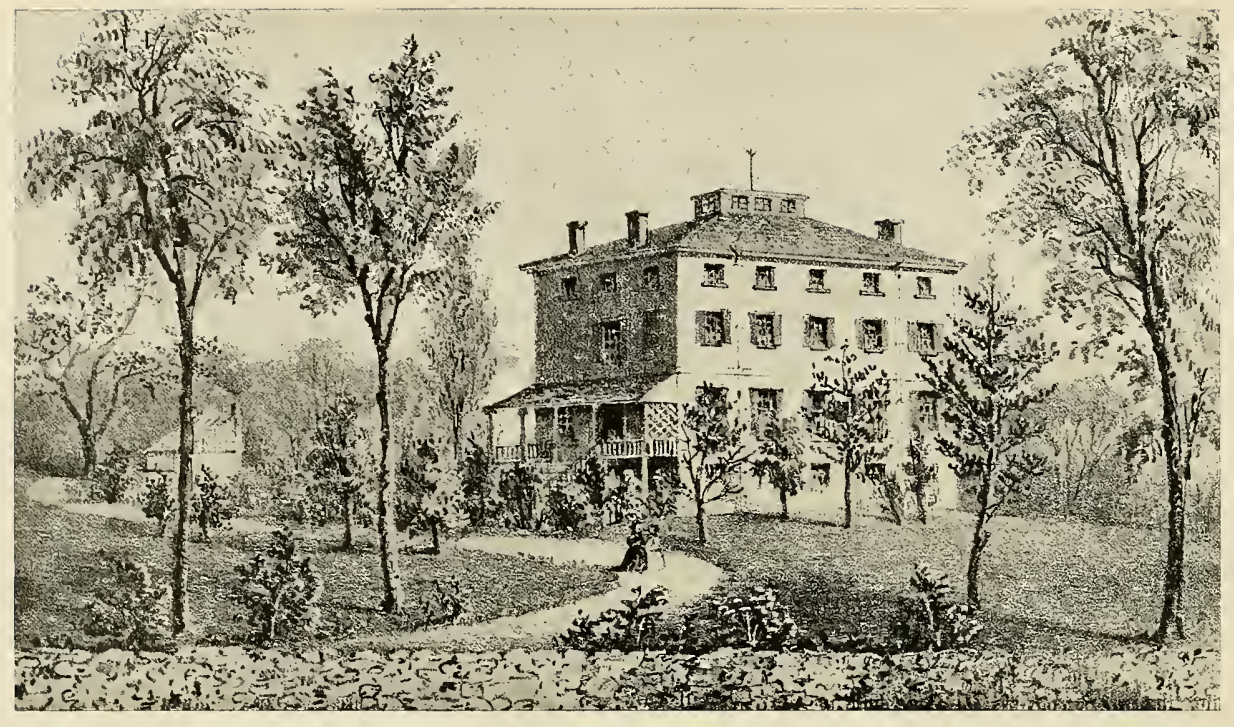

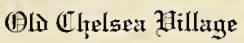

This region, west of 8 th Avenue from about Igth Street to 24 th Street, was named after a Soldiers' Home in London. The above is the residence of Clement C. Moore, who wrote that familiar poem beloved of children the world over, "Twas the Night Before Christmas."

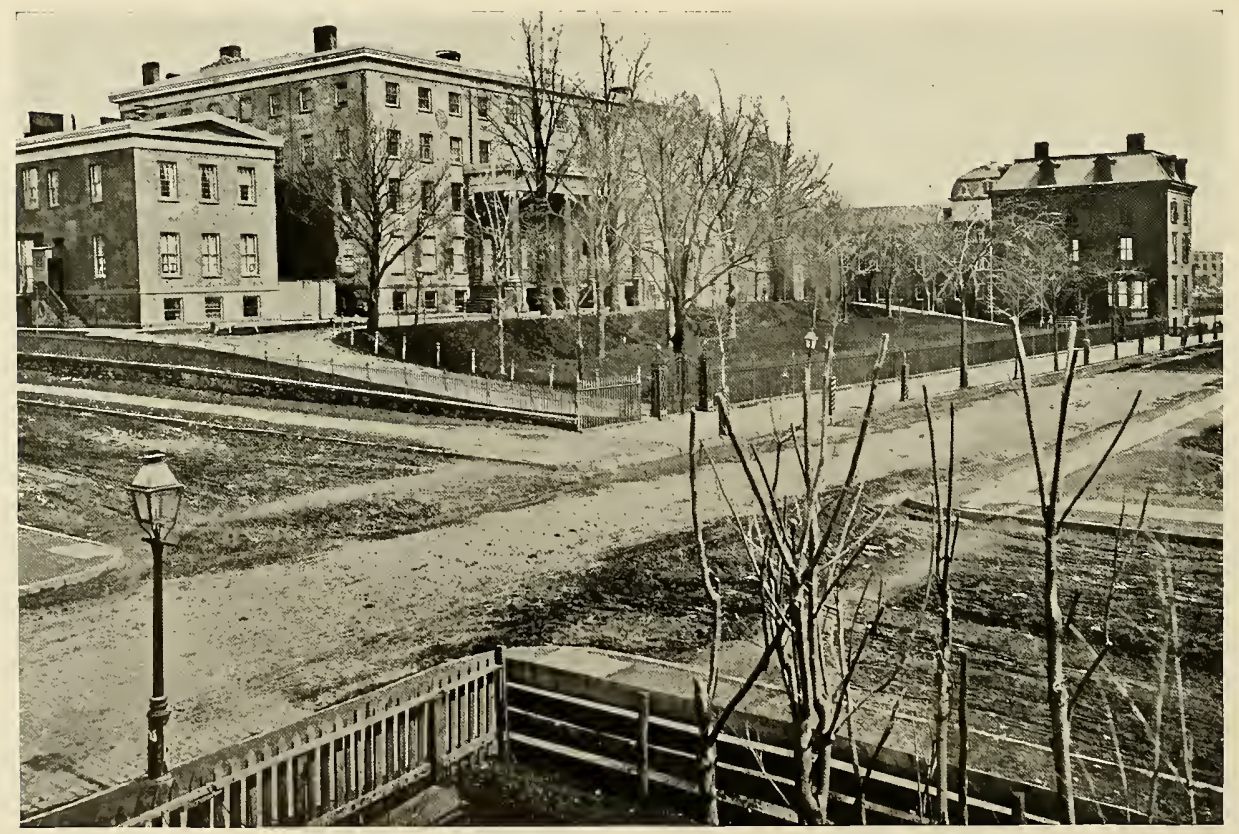

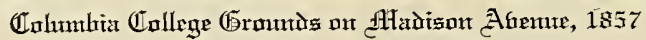

Columbia owns the property on Madison and 5 th Avenues between $47_{\text {th }}$ and 5 Ist Streets west to near 6 th Avenue, formerly the Elgin Botanical Gardens. This immensely valuable land is the source of Columbia's great wealth. 


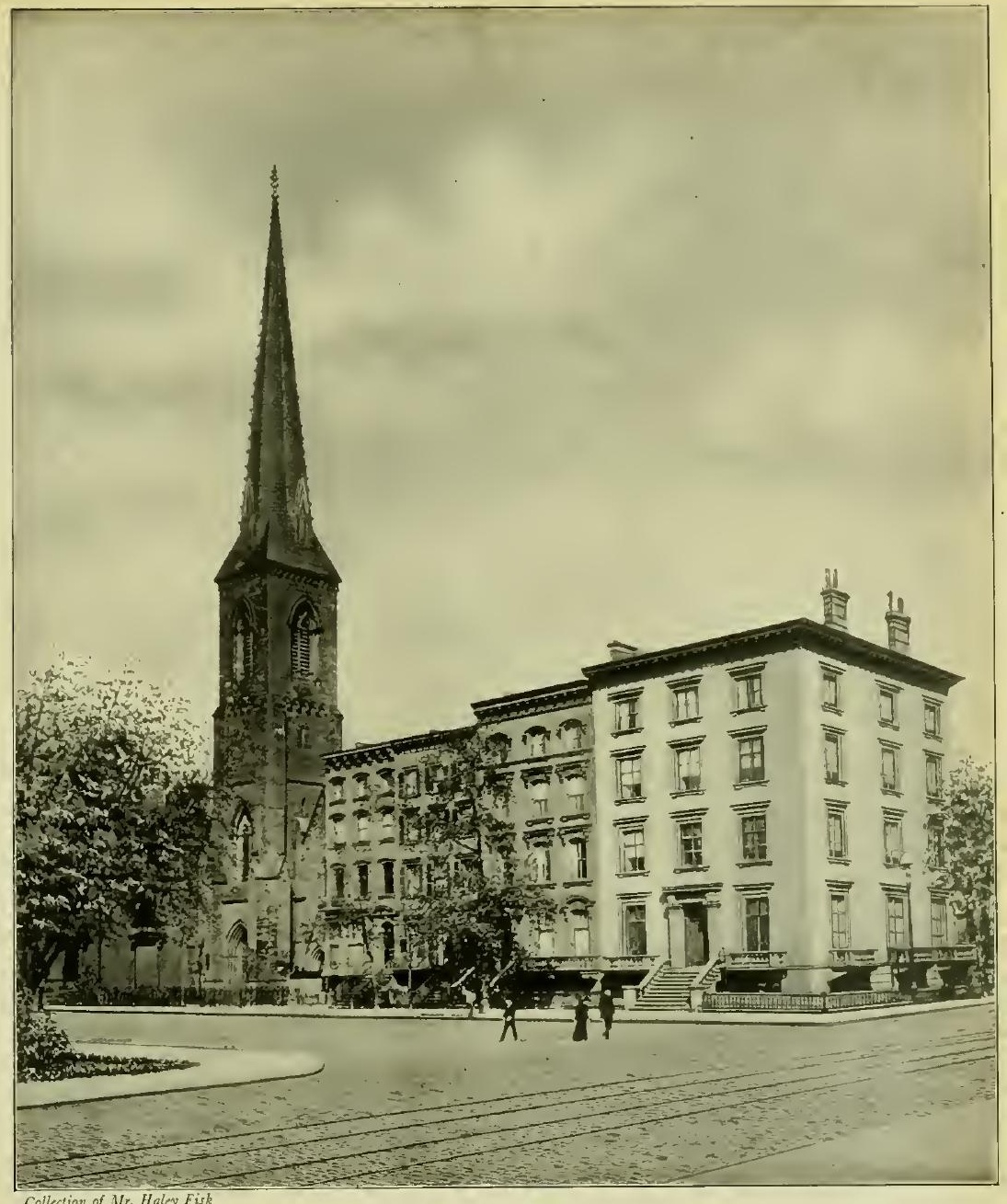

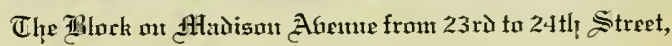
ahout 1885

The residence of Samuel L. M. Barlow on the right, Dr. Parkhurst's old church on the left. 


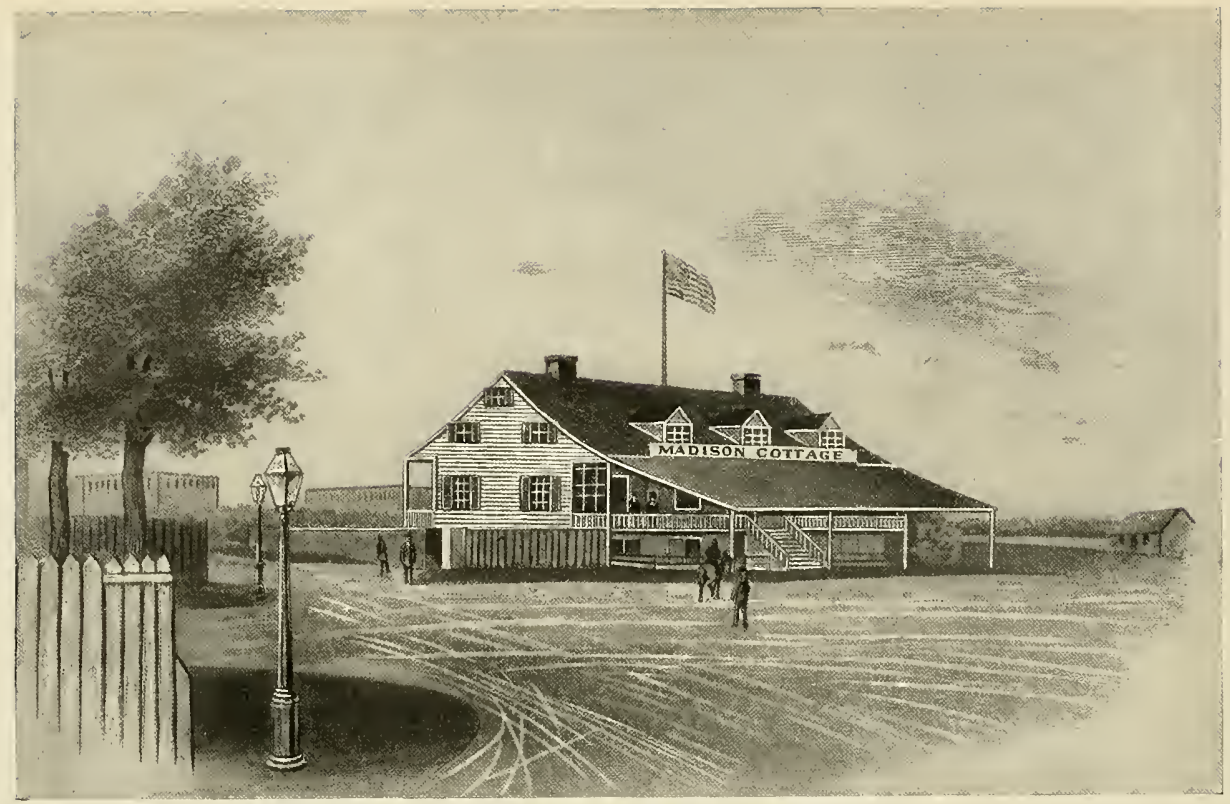

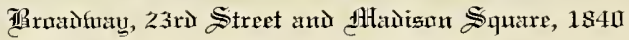

The Madison Cottage is now replaced by the Fifth Avenue Building, former site of Fifth Avenue Hotel.

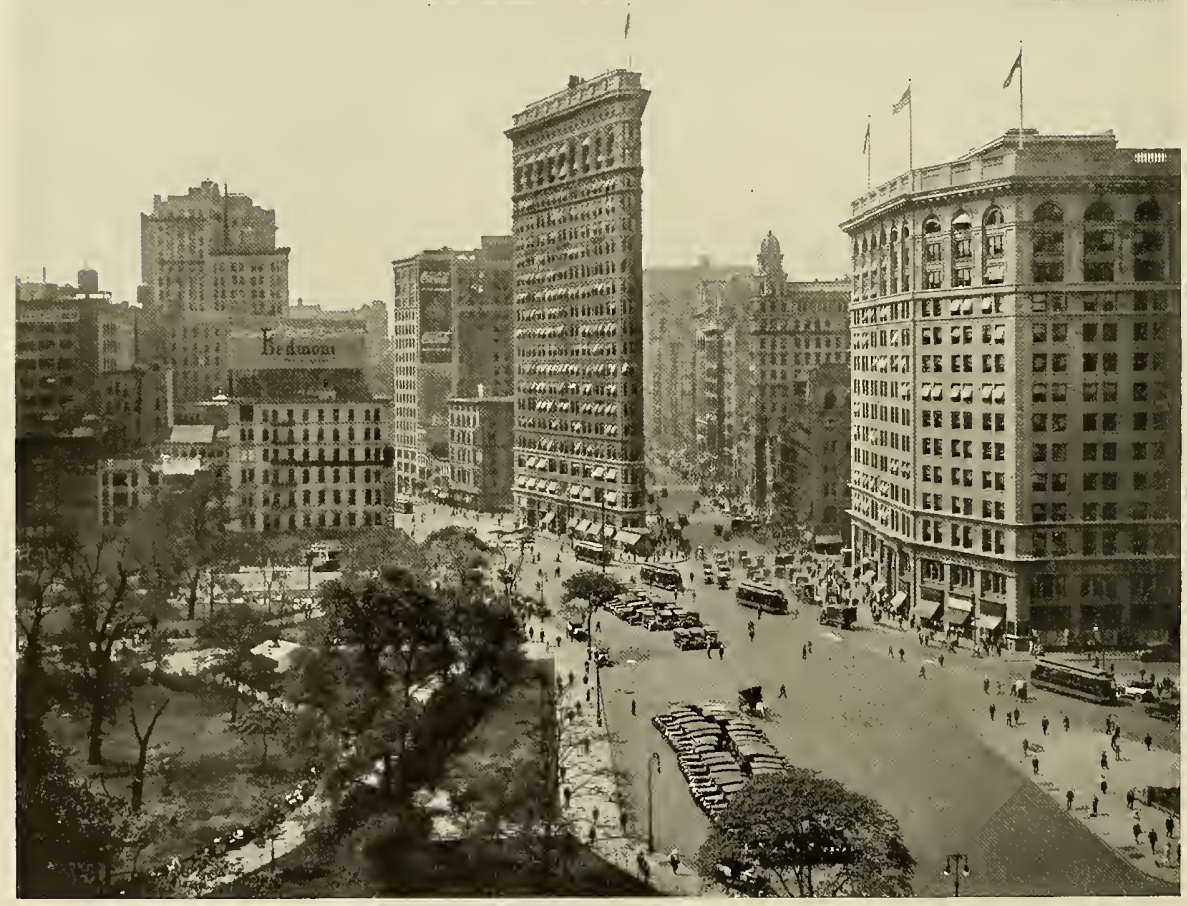

TR

The çelebrated Flatiron Building in centre. Fifth Avenue Building at right on site of old Madison Cottage. 


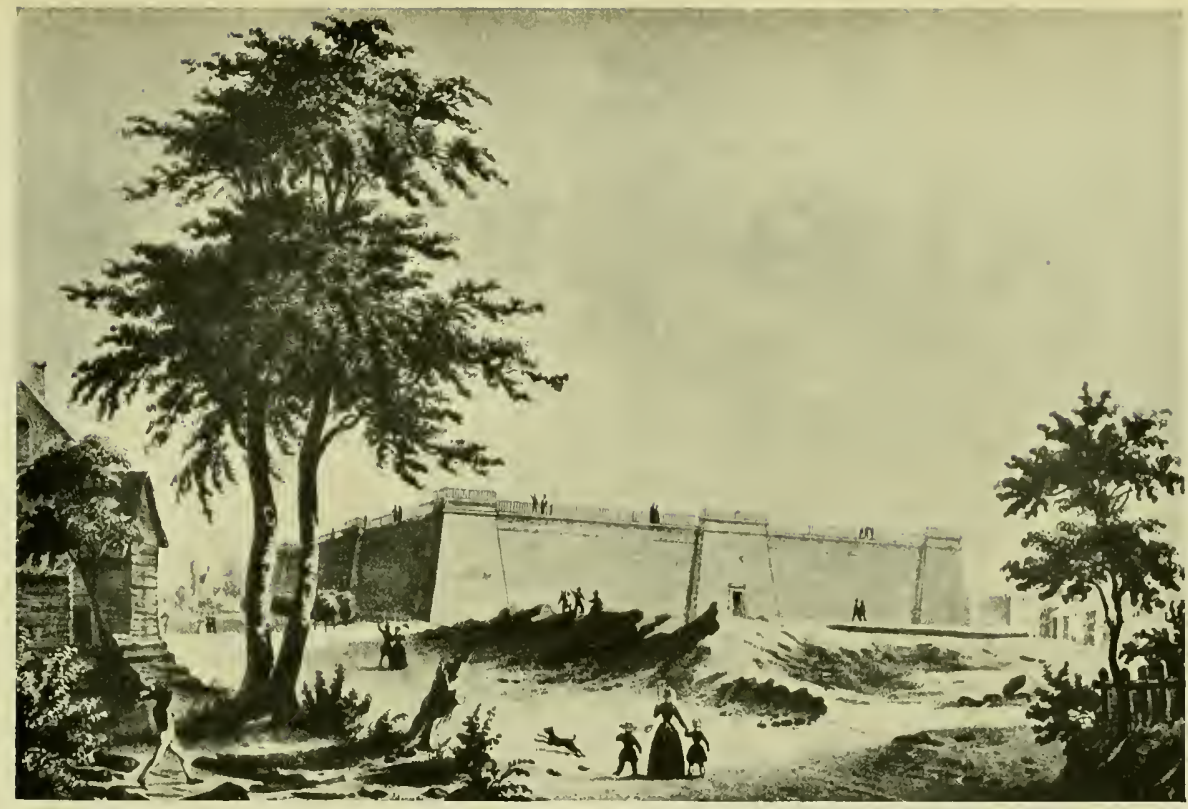

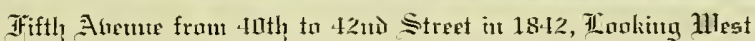

Showing the old Croton Reservoir that stood on the two blocks on Fifth Avenue, 4 oth to 42 nd Streets, built in $18+2$. This marked the first introduction of running water into the houses of New York. This site is now occupied by the great Public Library of New York-Astor, Lenox and Tilden Foundations.

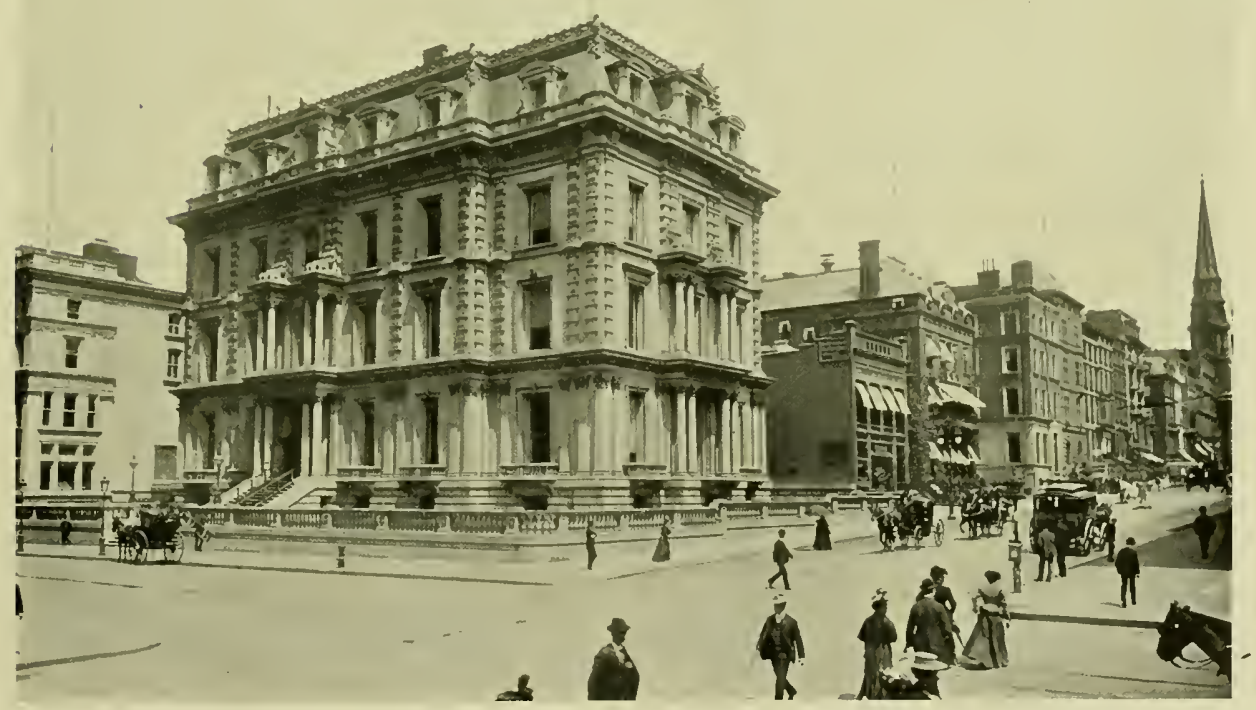

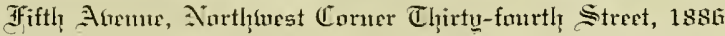

Showing the famous Stewart Mansion built by New York's first "merchant prince," $1886-96$, Alexander T. Stewart. Headquarters of the Democratic Club, but finally demolished to make room for the oldjKnickerbocker Trust Company, now the Irving. Columbia Bank and Trust Company. 


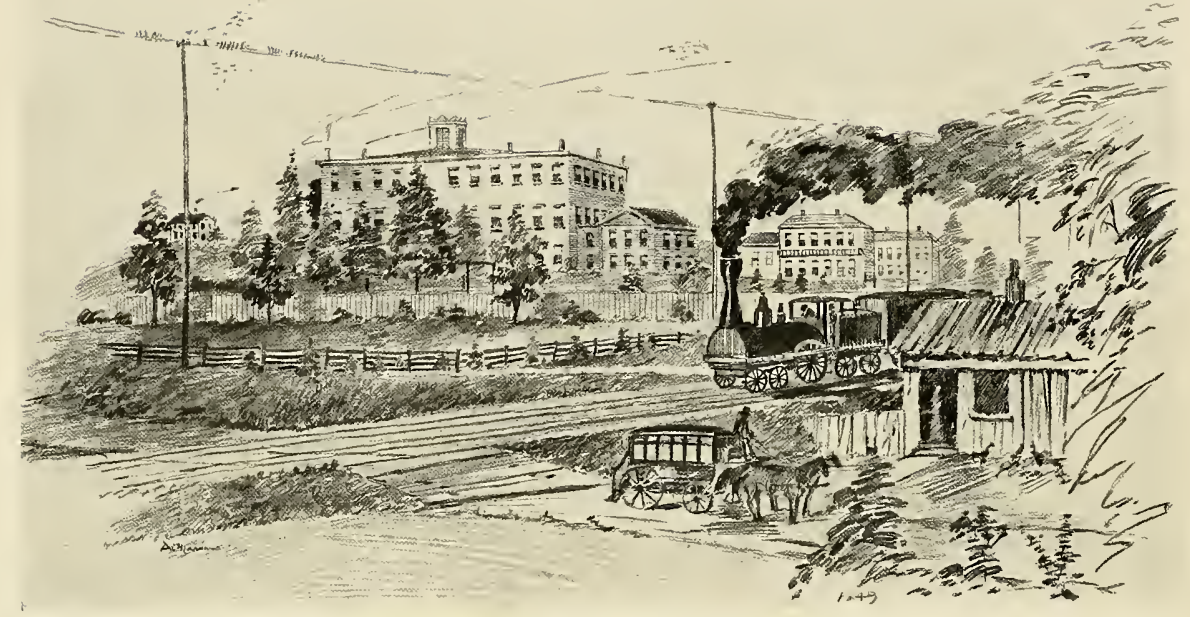

Collection of Mr. Lawrence B. Elliman

The (Graù Central Terninal Znue ahout 1840

The building at the left was the Deaf and Dumb Asylum afterwards occupied by Columbia College. The little wooden shack marks the site of the present Grand Central Terminal.

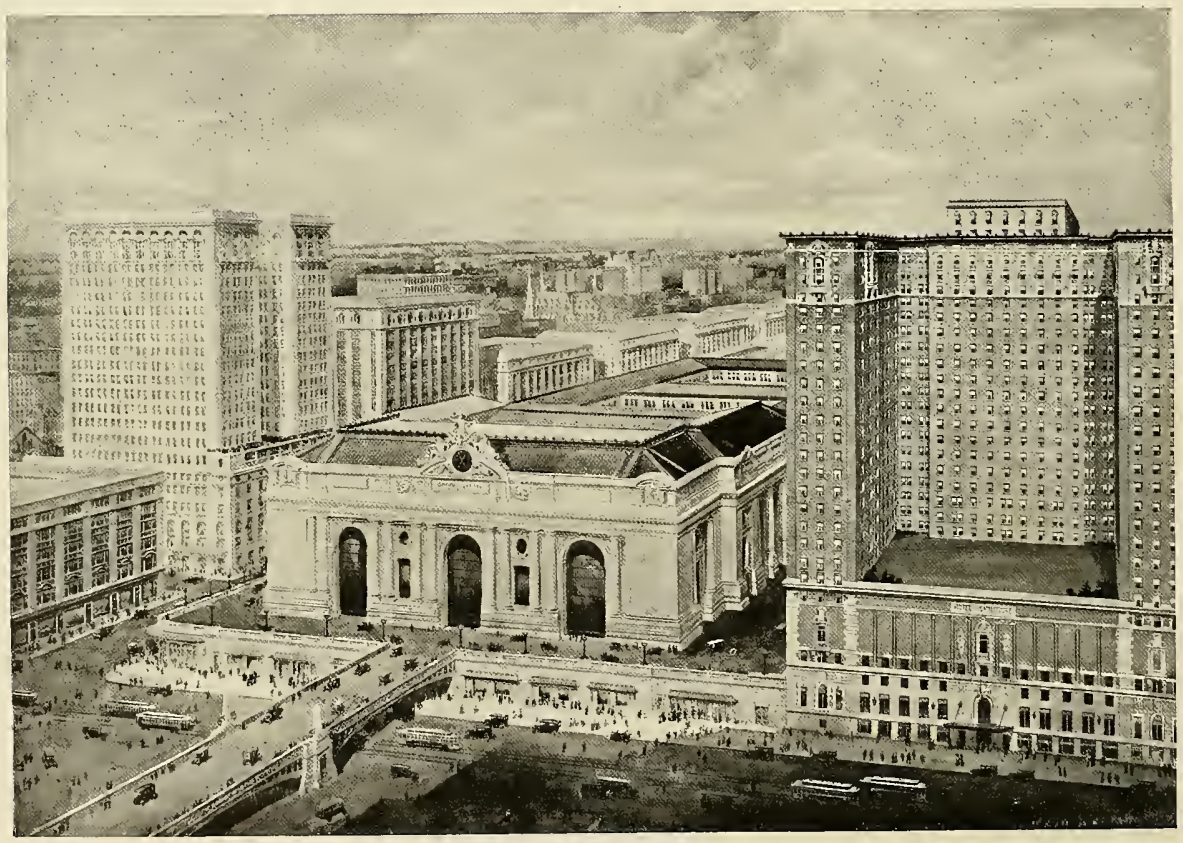

The (Gramì Tentral Zane Tòay

The main station is in the centre. The Hotel Commodore is at the right; the Biltmore at the left. Park Avenue viaduct in the foreground at the left, crossing over 42 nd Street, and connecting Park Avenue which continues back of the Terminal. 


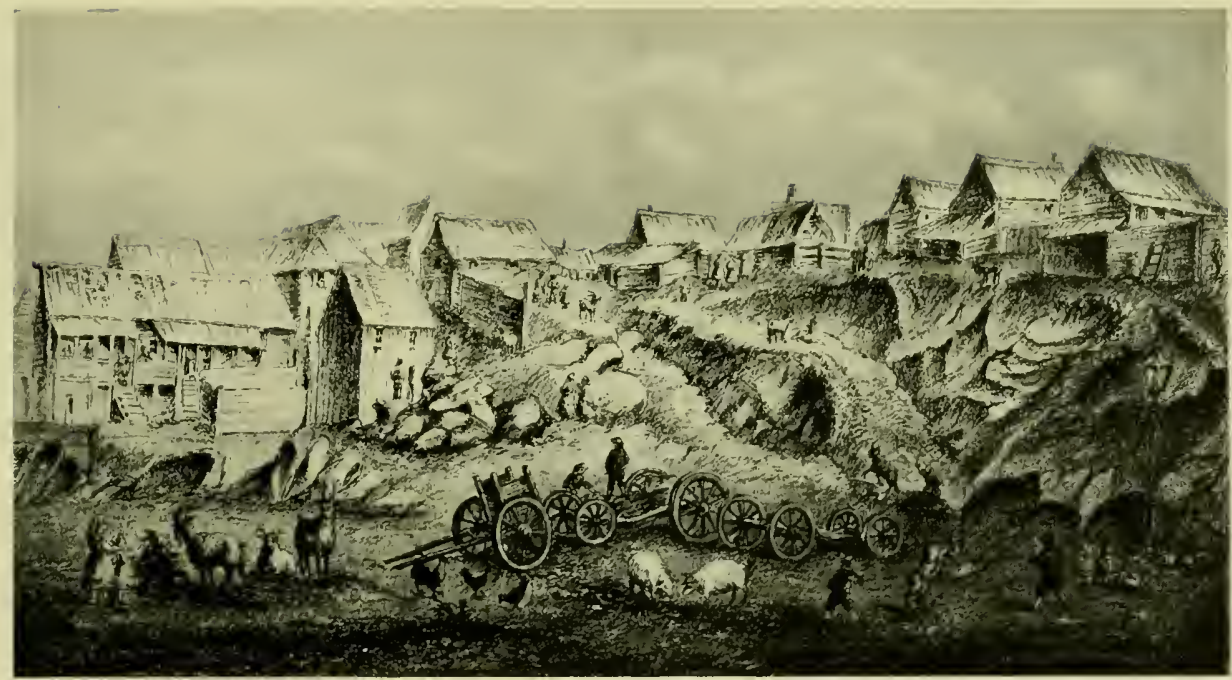

Valentine's Manual

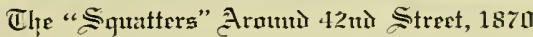

All the region north of 2 nd Street was a rocky neighborhood, tenanted by "Squatters," who put up a great battle when the work of building the Grand Central began. These Squatters had a precarious existence and depended on gonts for a considerable part of their living. They were a unique feature in upper New Y'ork for many years. It was a wild country north of +2 nd Street in the $60^{\prime} \mathrm{s}$ and these rookeries covered all of what is now Central Park and along Fifth Avenue east, as well as 4 2nd Street.

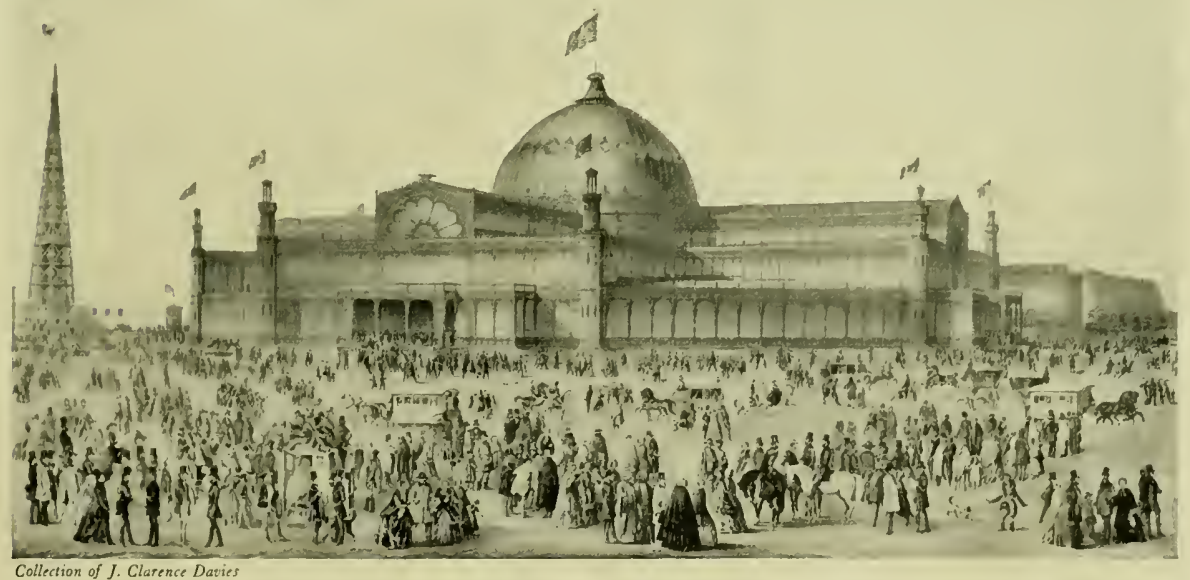

The $\mathbb{C}_{\text {rugstal }}$ latalare

Not far from the rocks and shanties of 42 nd Street on the east rose this palace of Industrial Arts on 42 nd Street on what is now Bryant Park. It was known as the Crystal Palace and was the forerunner of all the expositions and world's fairs that have since succeeded. It was erected in 1853 with P. T. Barnum as president and Washington Irving among the directors. It caught fire one afternoon in ' 58 and was burned to the ground. At the extreme right is the Croton Reservoir, Fifth Avenue and t2nd Street, shown on another page. 


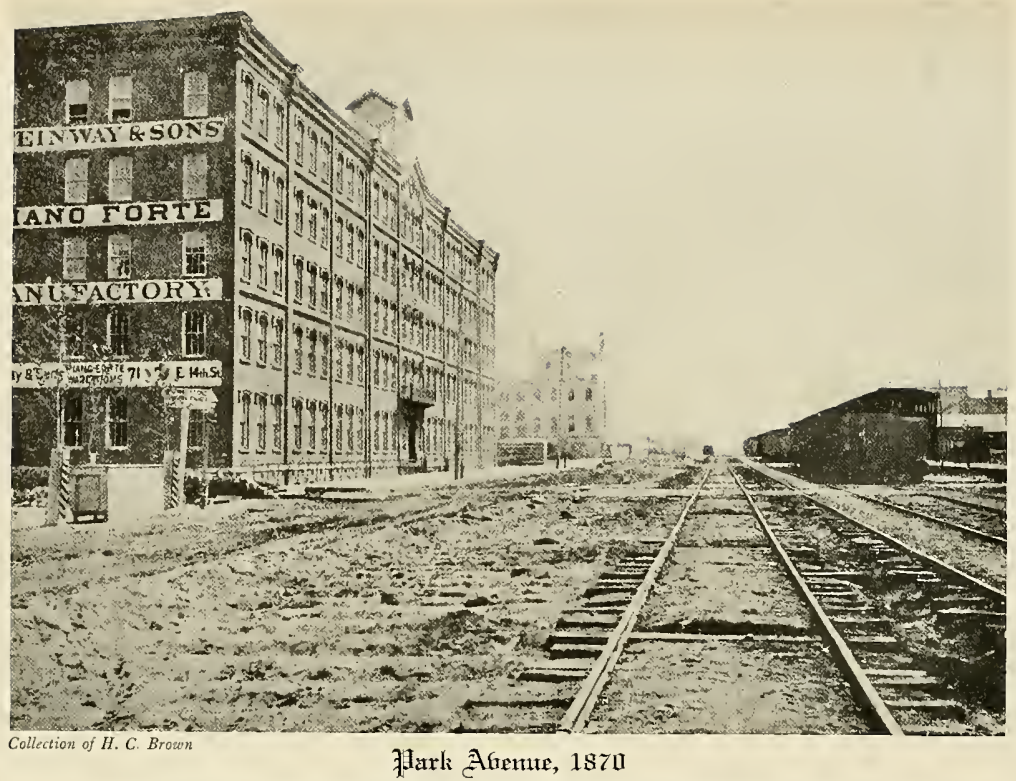

Park Avenue north of the Grand Central, between 53rd and 5oth Streets, while the tracks were still on the street level, about 1870 . Steinway's Piano factory and other buildings were removed to make room for the present splendid apartment houses.

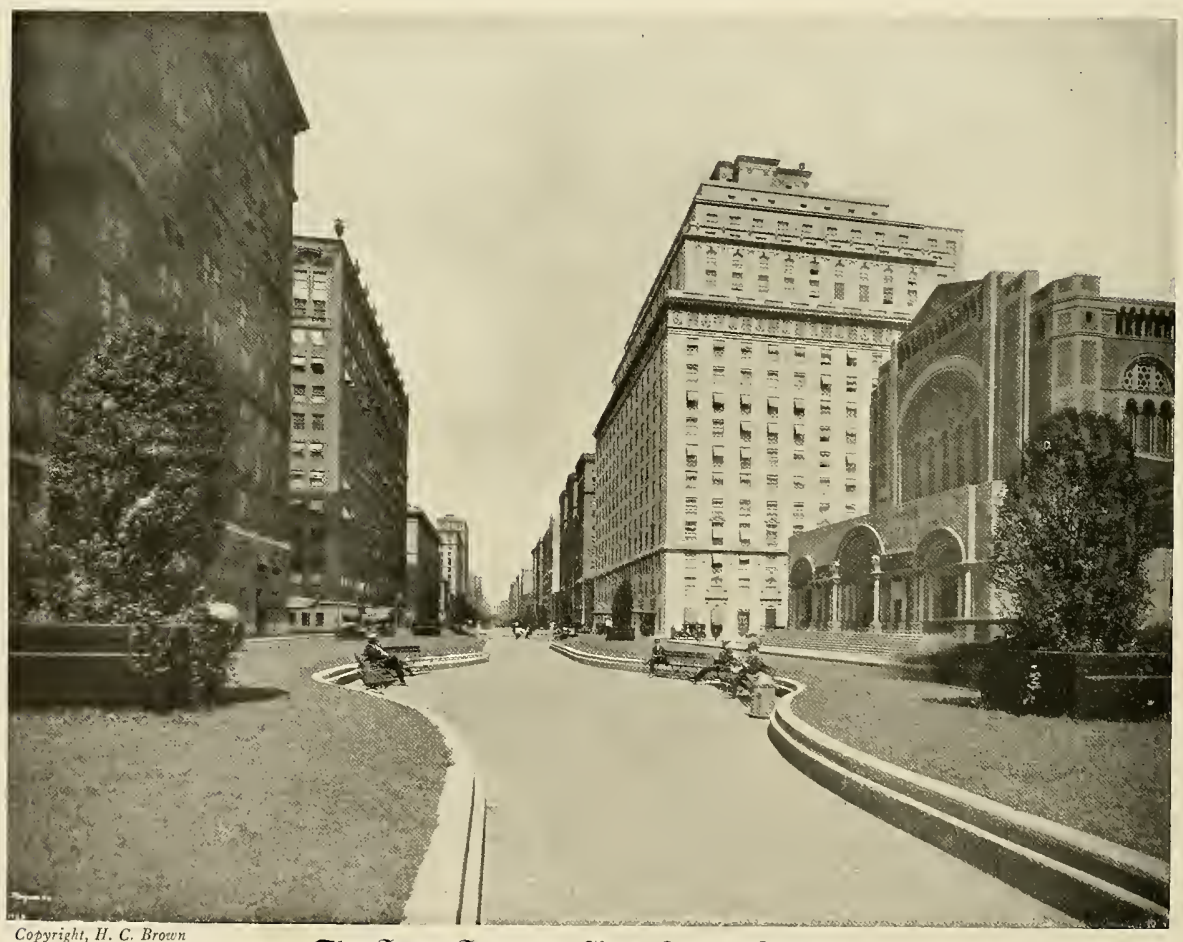

Thy Sante Sertion of łatark Afrenue Tòay

It is now one of the most highly developed residential sections in town. At the right is St. Bartholomew's, one of the best known churches in New York. Adjoining it is the Ambassador Hotel. 


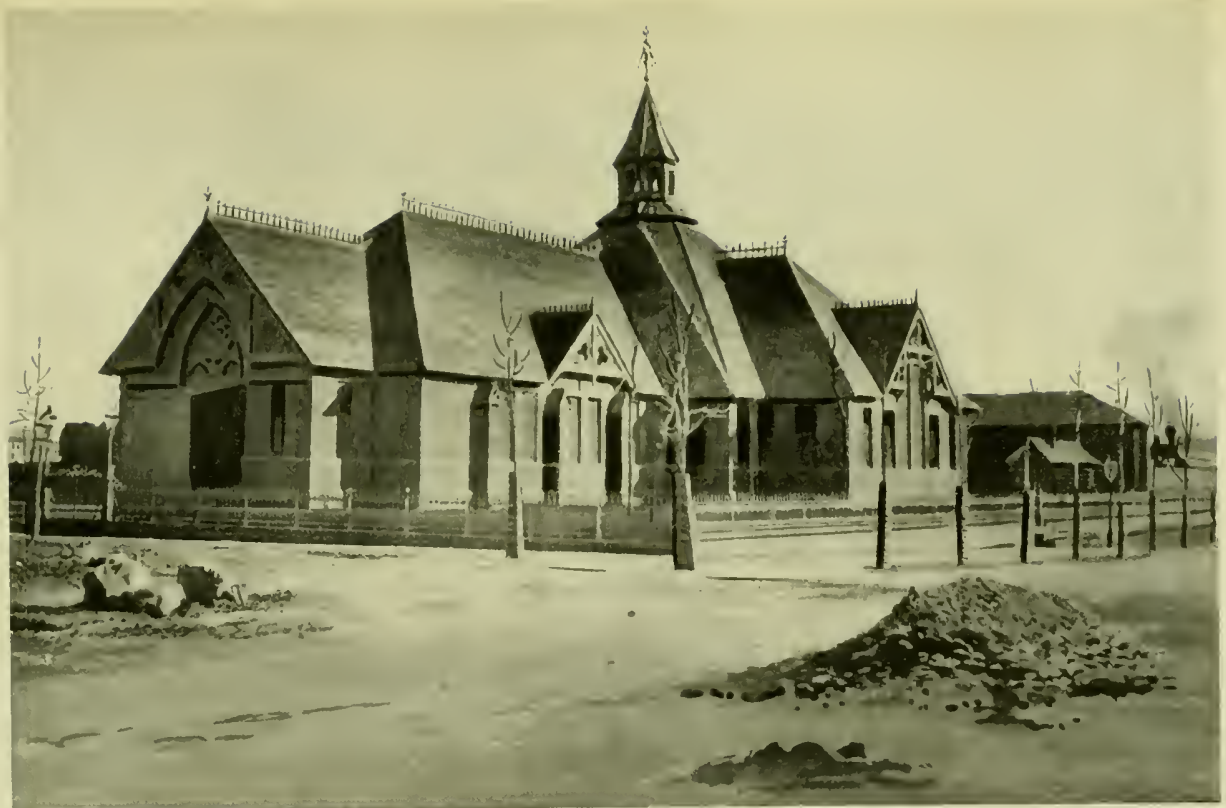

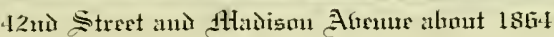

This is the corner of and Street and Madison Avenue, about 1864, as it appeared while occupied by Dr. Tyng's Chapel. The depot was not yet built. A wood-burning locomotive can be seen in the distance at the right where the Grand Central Terminal now stands.

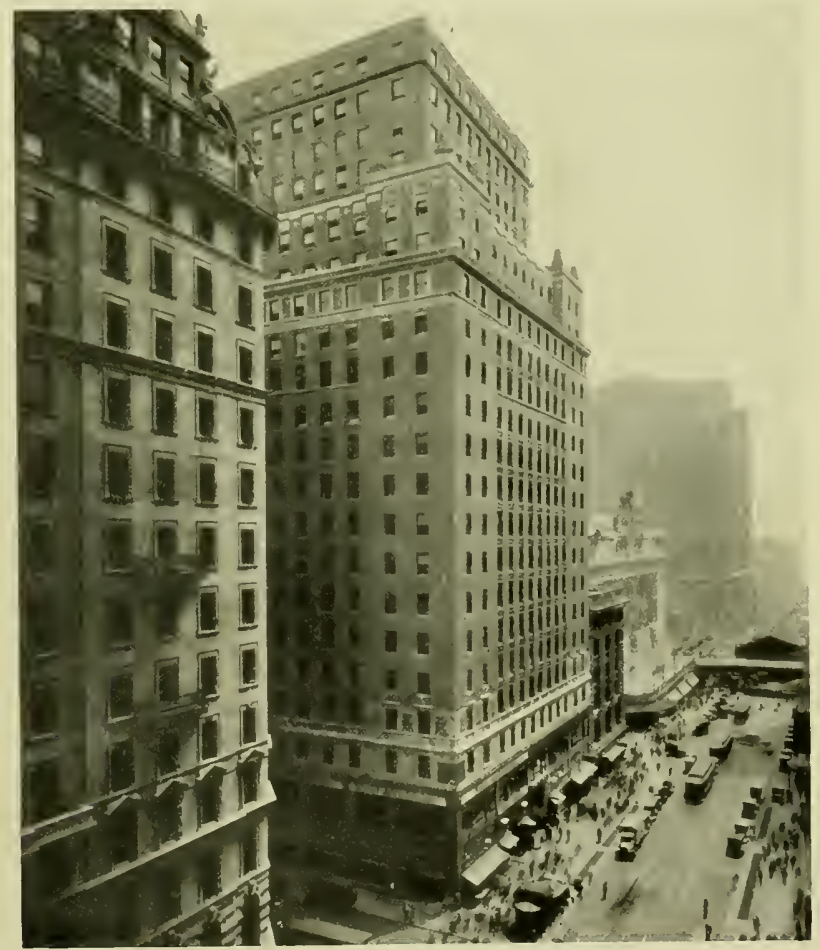

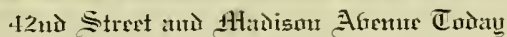

The corner of $4^{2 n d}$ Street and Madison Avenue as it is today, showing a 25 -story building in place of Dr. Tyng's little chapel and the great station of the New York Central in the distance where the locomotive is in the upper picture. The Hotel Commodore at the right. 


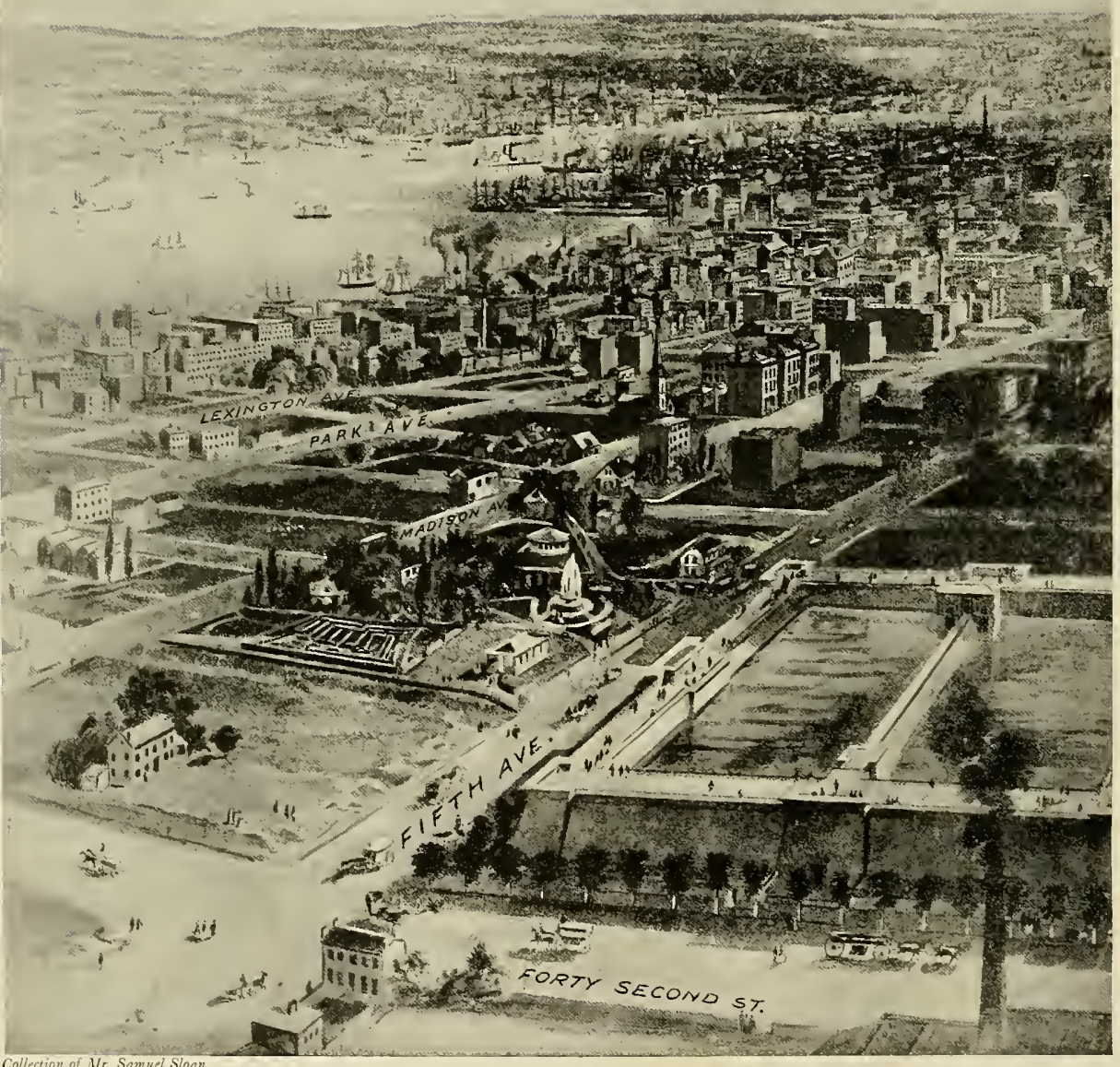

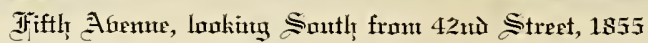

At the right is the old Croton Reservoir where the Public Library now stands. Directly opposite is the block between $+2 n d$ and $+1 s t$ Streets, now covered with modern skyscrapers. The little building opposite the toth Street corner of the Reservoir was Croton Cottage, a popular road house at the time. Building lots could then be bought in this section for-a thousand dollars and less. Contemparary part view, by W'all, drawn from Latting's Observatory opposite the Crystal Palace on 4 and Street 


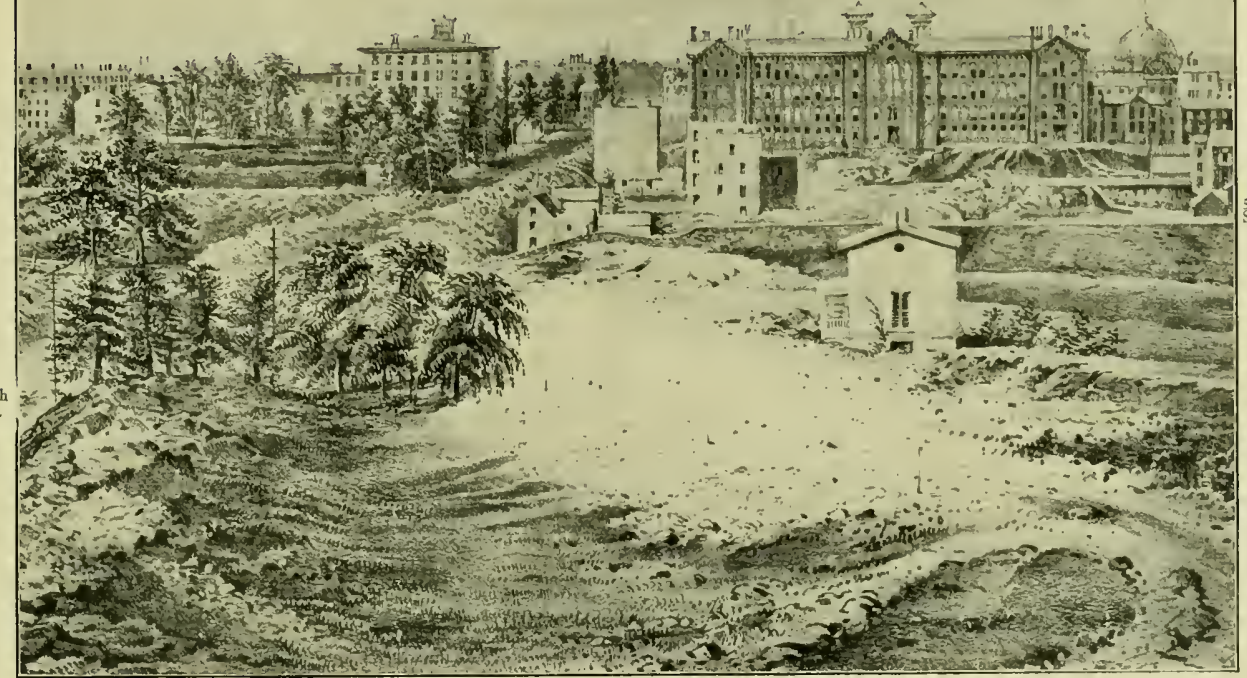

From Valentine's Manual 1850

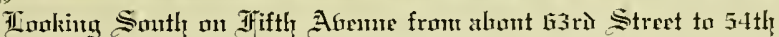

The large building at right is St. Luke's Hospital and Columbia College is at left. The dirt road is Fifth Avenue. The small wooden building in centre on the Avenue is the New York Skating Club. The Lenox farm is at the left.

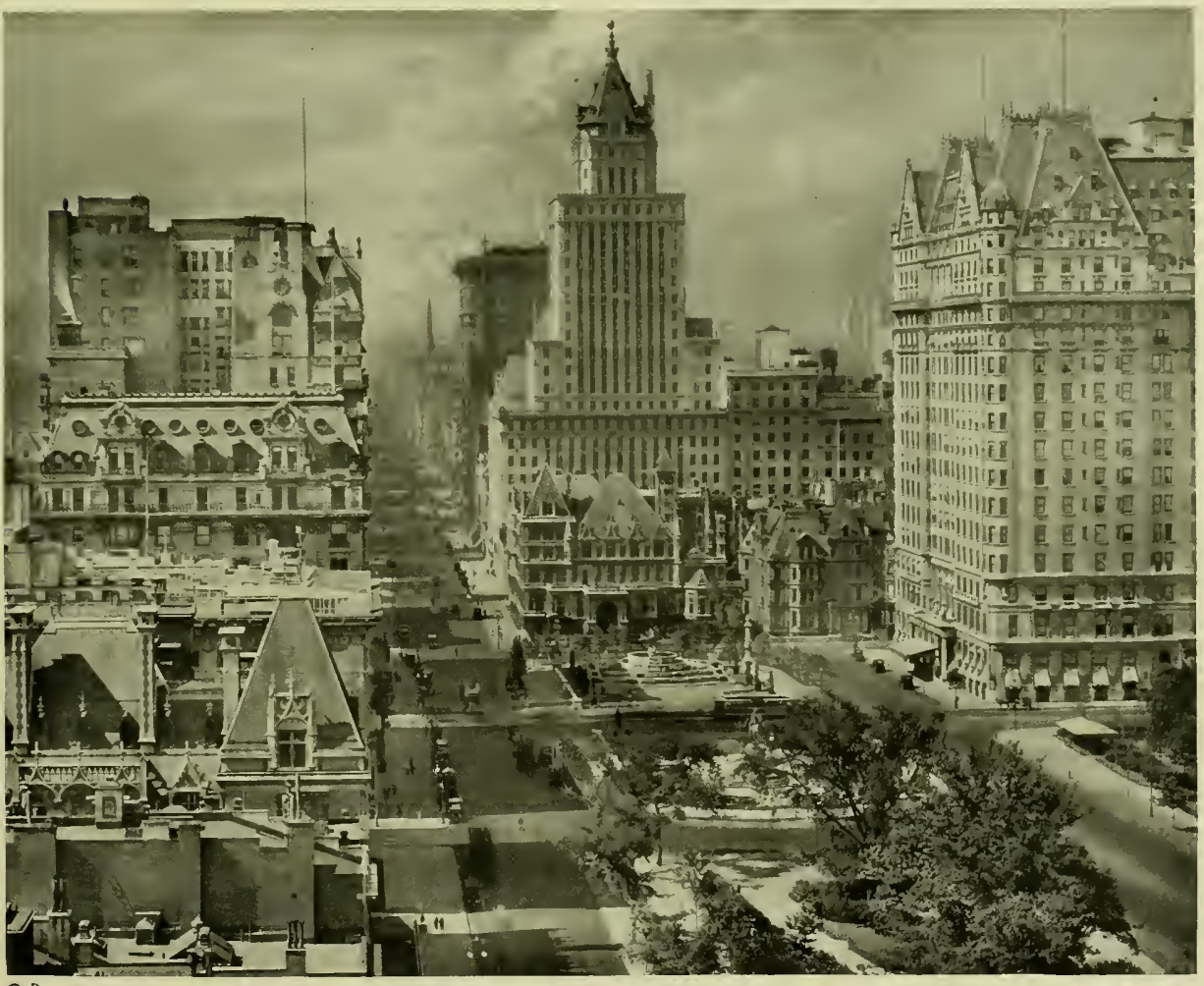

() Byron

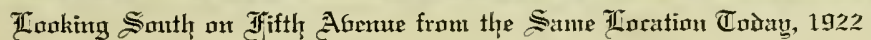




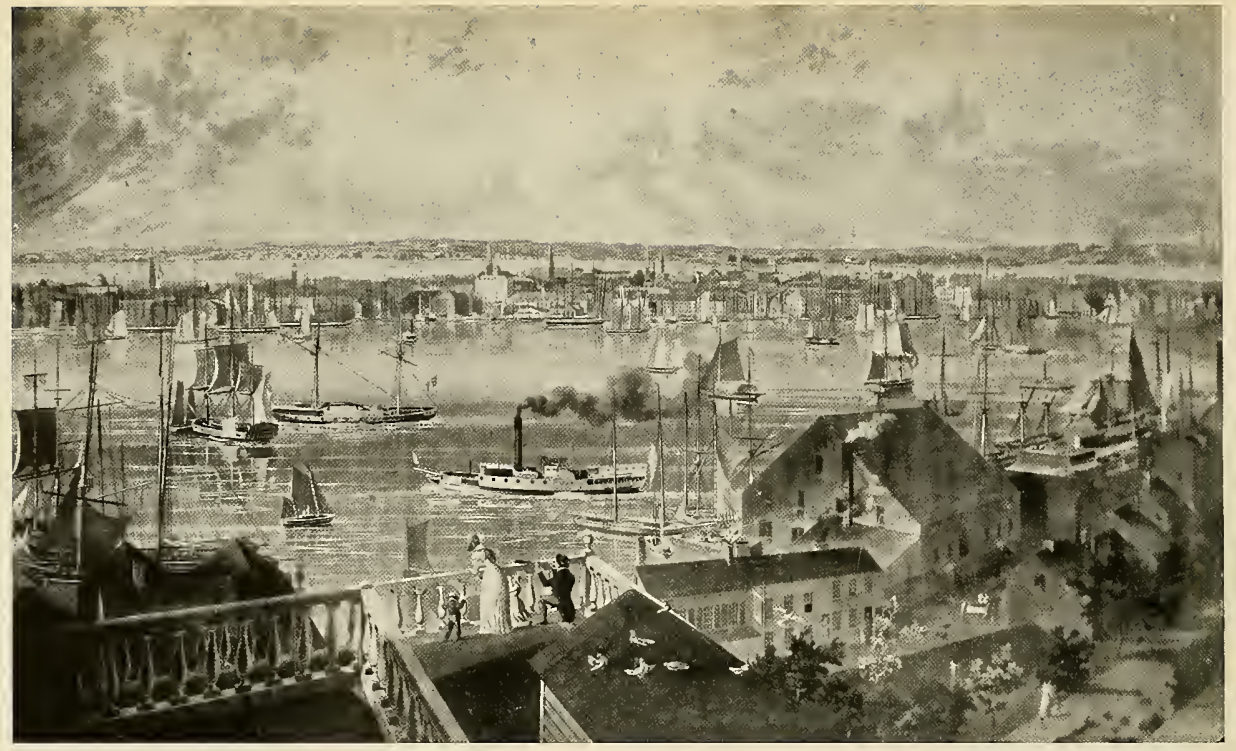

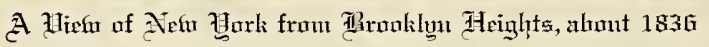

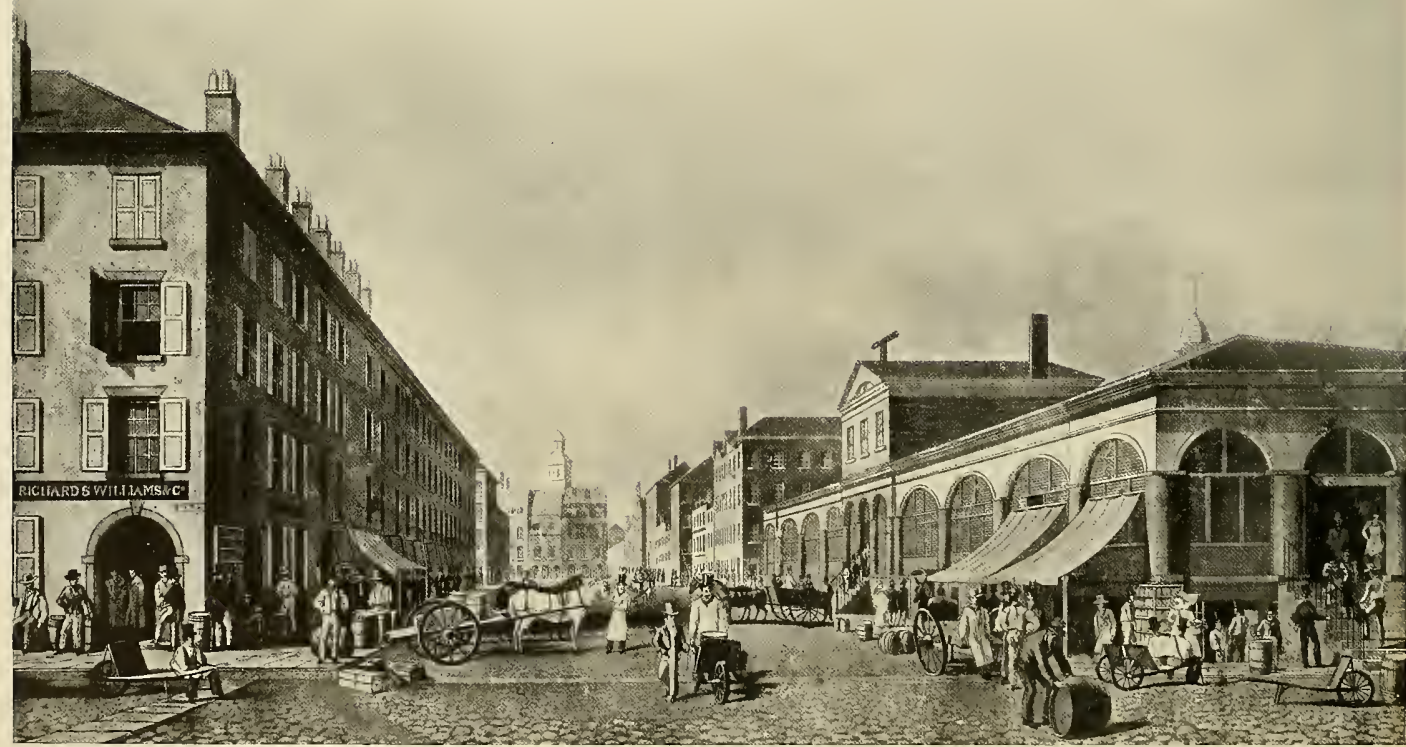

Sunth Street anto Tfulton Altarket, altwont 1835

Showing Richard S. Williams \& Co., our oldest grocery, at left and market at right. Sea food has always been a specialty, the boats

coming right to the market on opposite side of South Street. 


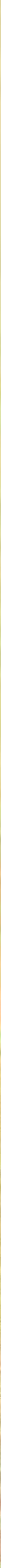

IBatteru Zlark anti State Street

This view shows the striking contrast between New York buildings of the early nineteenth and of the twentieth centuries. The little houses on the right were in 1810 or thereabouts the most imposing in town, and are all that remain of this famous block, which included the homes of James D. Wolfe, Robert Lenox, Thomas W. Ludlow, Archibald Gracie, Joseph P. Phoenix, Moses Rogers, Chancellor Livingston, Robert Fulton, John B. Cole, and others. For many years this stately old street, commanding, as it did, a splendid unobstructed view of one of the magnificent harbors of the world and the wooded heights of Brooklyn across the river, was deservedly the most fashionable and exclusive residential section of the city. 


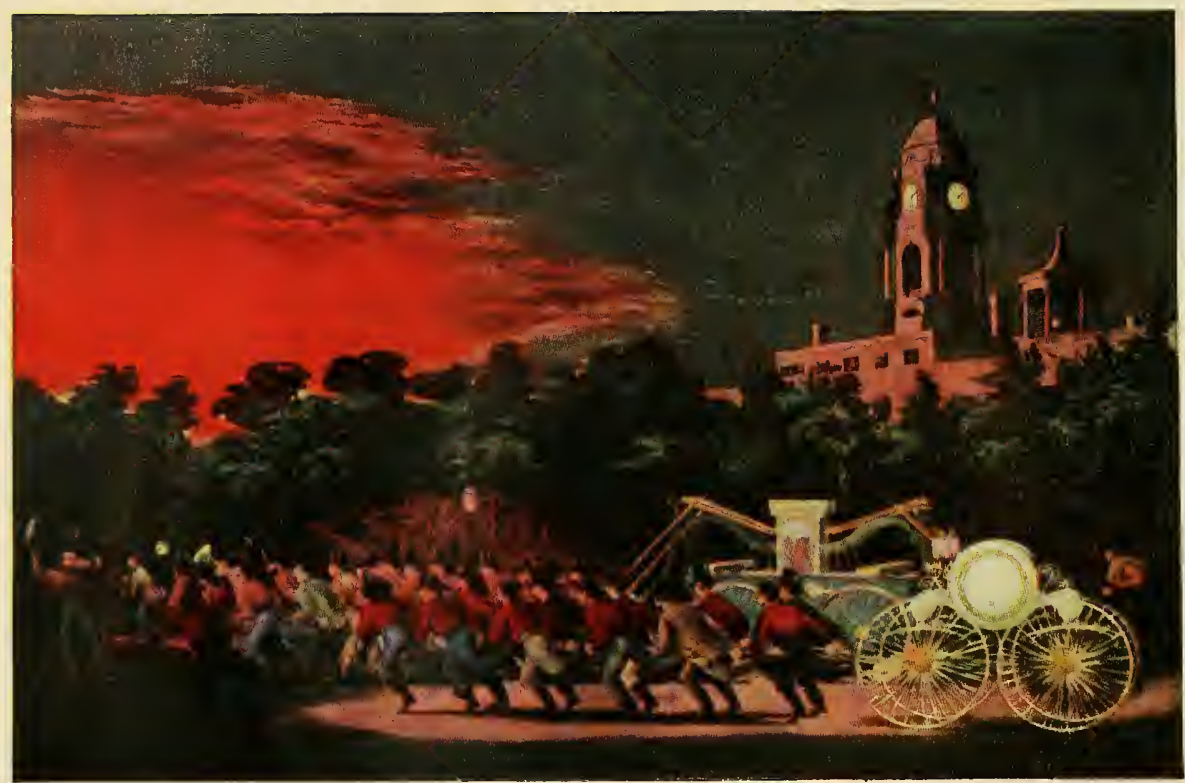

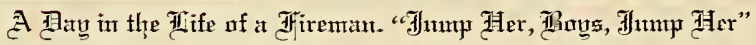

Half a century has barely passed since New York depended entirely upon volunteer firemen for protection against this great public danger. She was last among the great cities to change from the old system to the new. In these old Currier \& Ives lithographs the figures shown in the pictures are portraits of well known members of the various companies, old Harry Howard showing conspicuously among them. This print shows the fire apparatus being drawn past City Hall Park.

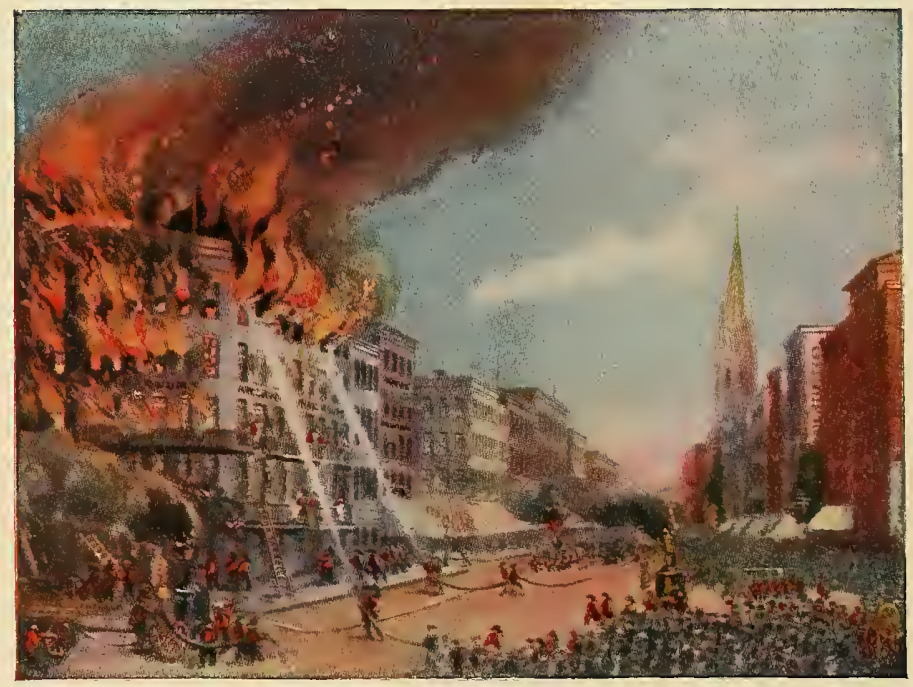

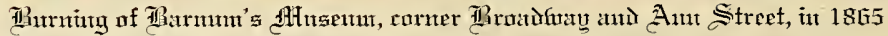

One of the best remembered incidents in Old New York. Thousands of men still living "stond on the corner opposite holding their father's hand" while the fire was in progress. A huge dead whale from the Museum lay in the streets for several days to the great discomfort of the neighborhood before it was removed. This fire also marked the last appearance of the Volunteer Firemen, an organization that had existed since the city began. 


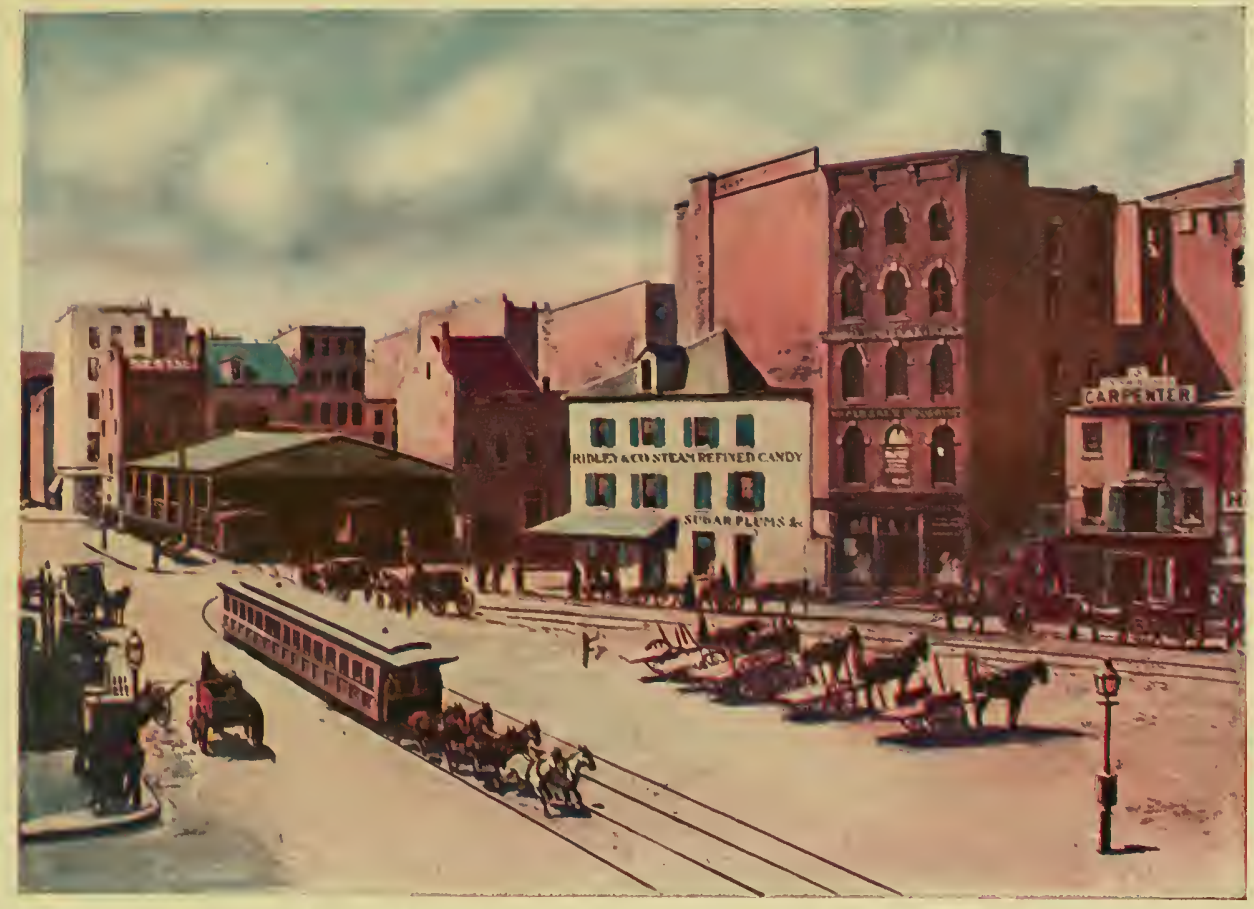

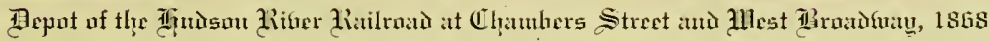

The main terminal was at 3 oth Street and Eleventh Avenue. From that point passengers continued the downtown journey in long horse-cars, which becane known as the "Dolly Varden" cars

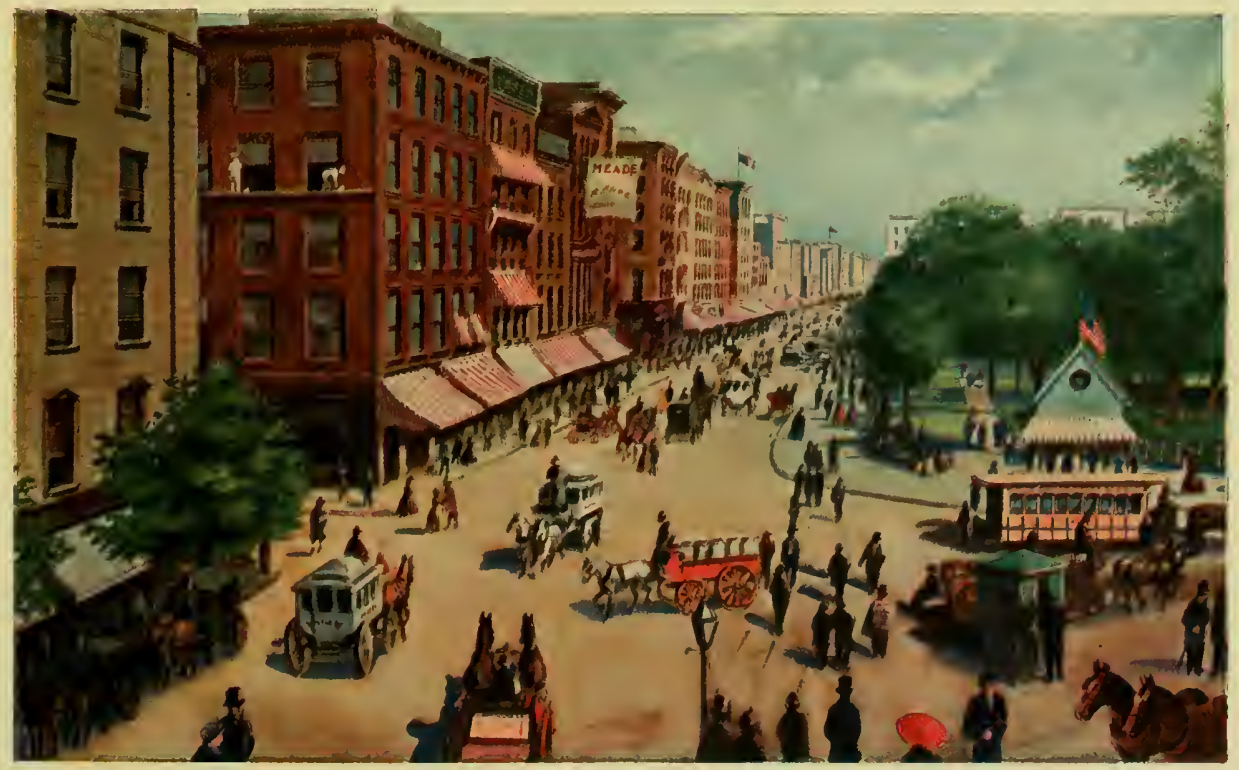

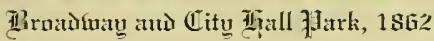

A Brady photograph, showing trees and the wide stretch of awnings all along Broadway. The wagons, stages and costumes are all characteristic of New York in Civil War days. 


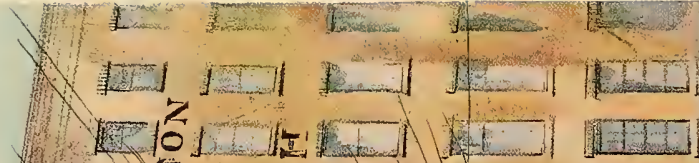
(1)

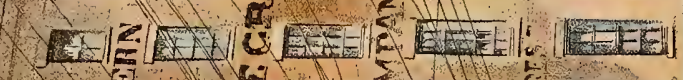
E-E

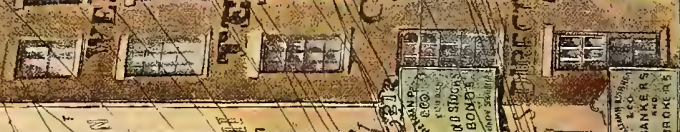
- 1 I $4 f^{2}{ }^{2}$.
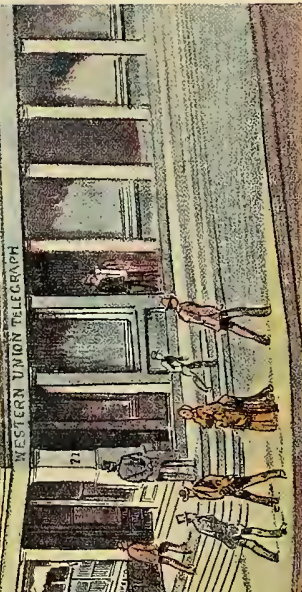
$(-3-1$ -

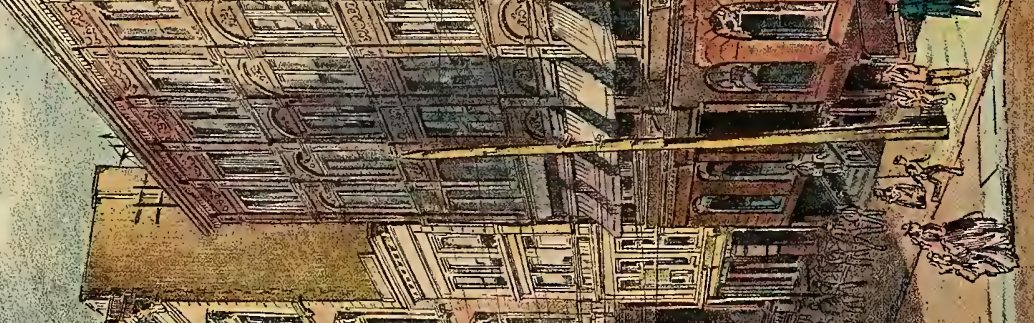
$1=V=16=$

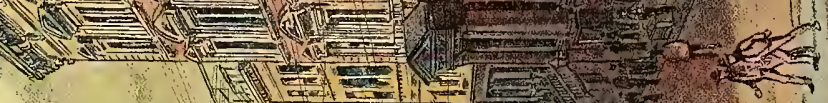
W $=3=15$

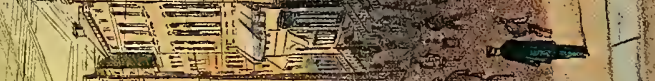
Din

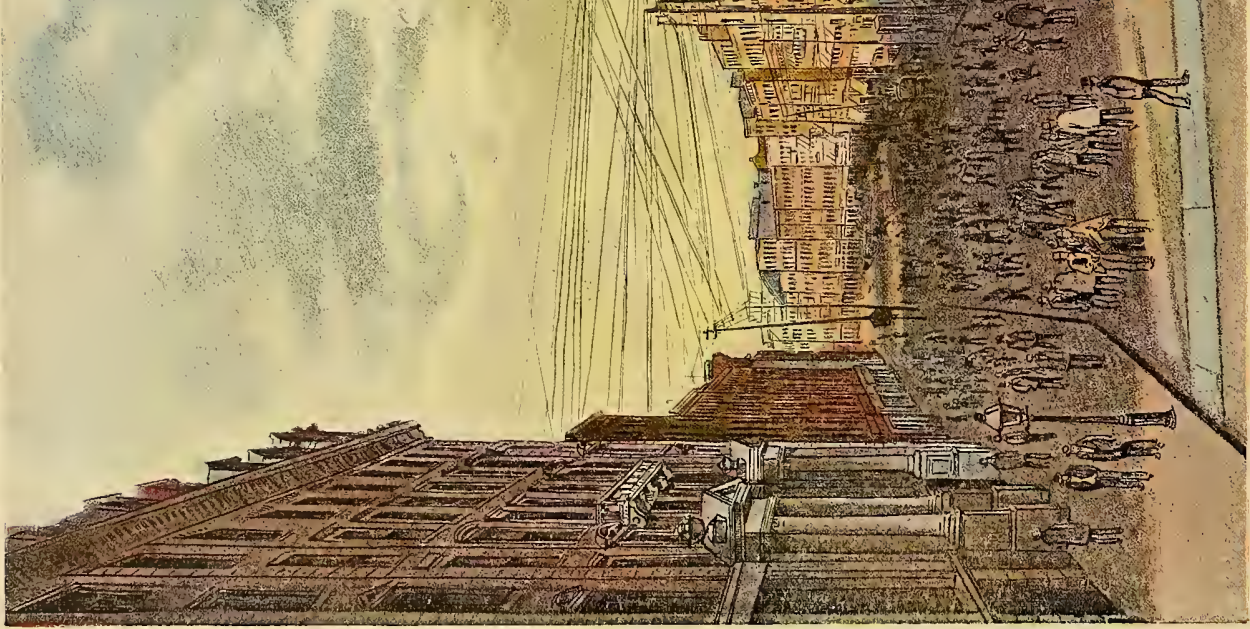




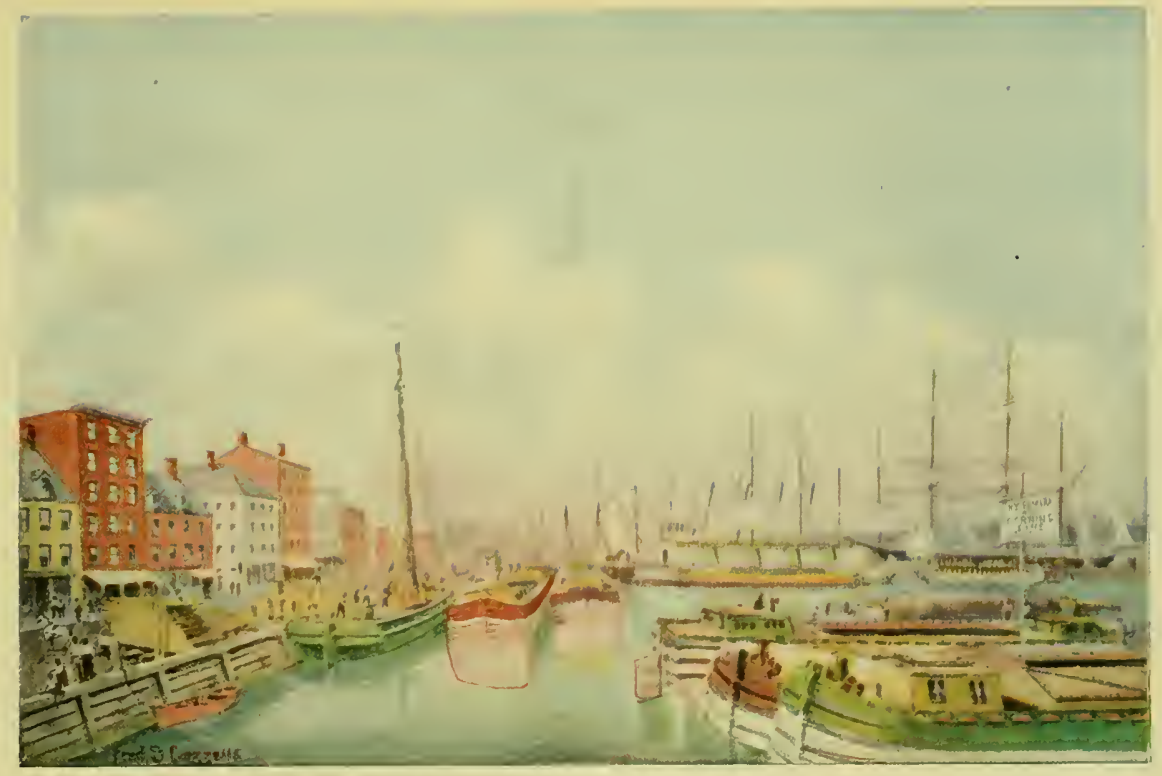

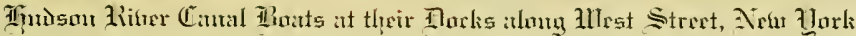

Until the steamboat and railroad were fully developed, an immense business was done by Canal boats which came down the Hudson from Albany. The present Barge Canal is expected to bring back some of the old time popularity and cheapness of water transportation.

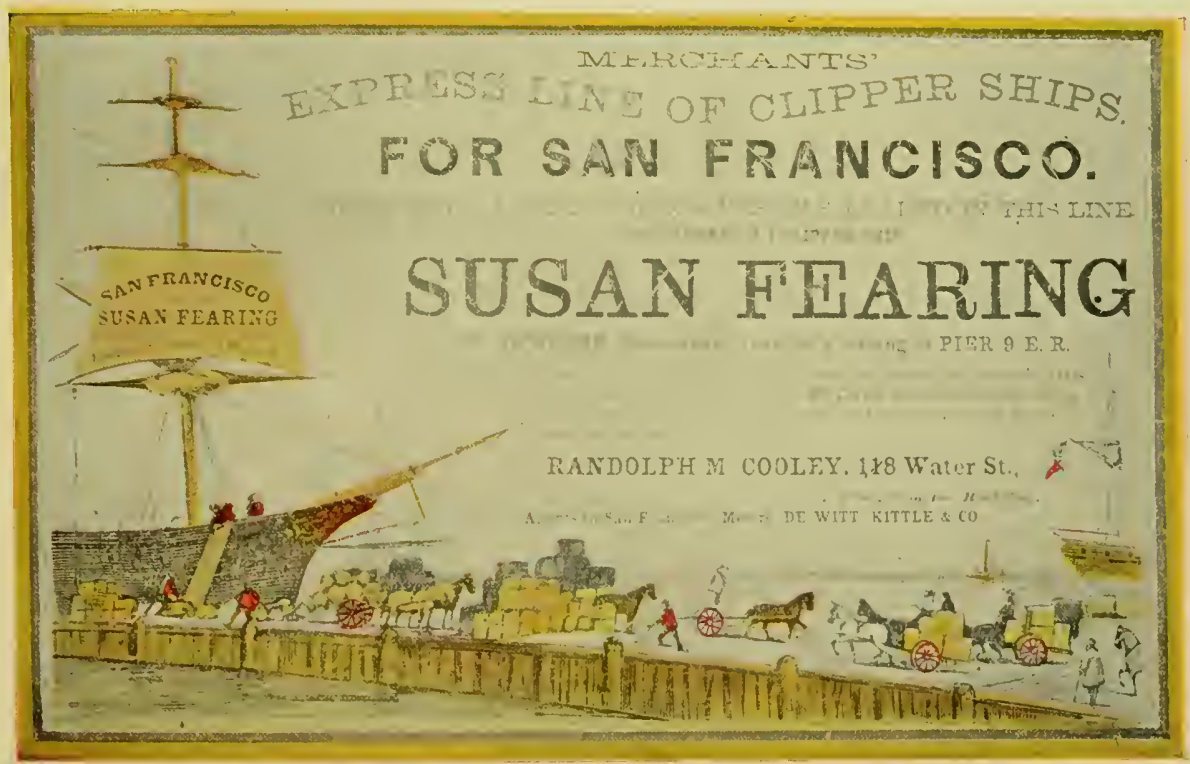

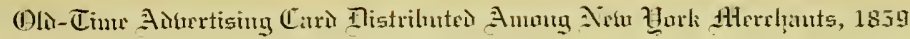

All the old firms distributed these fancy colored cards and their popularity created the craze for lithographed business cards that raged so violently in the early 80 's. This vogue virtually created the business of lithography in this country 
Pemantis en inenday Seamen $n$

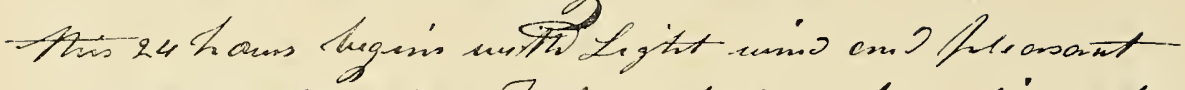

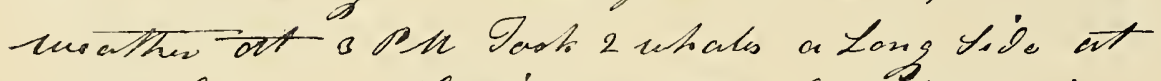

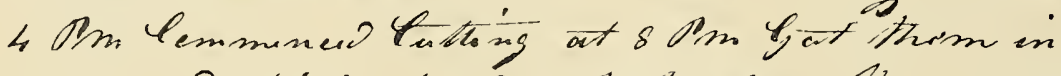

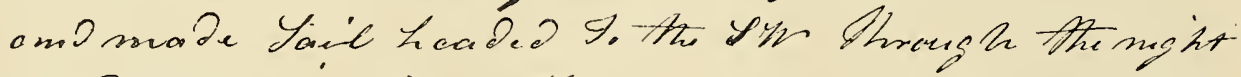

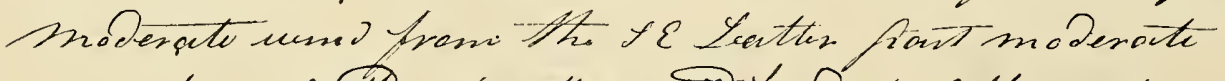

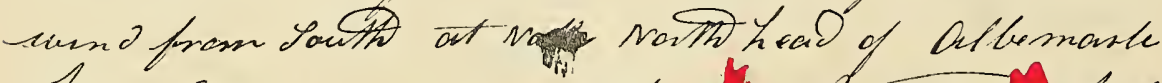

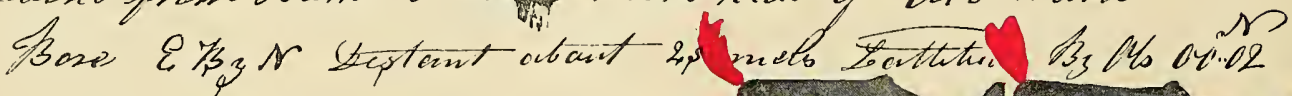

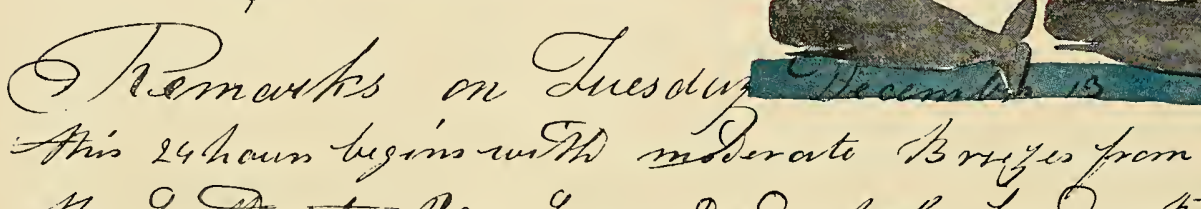

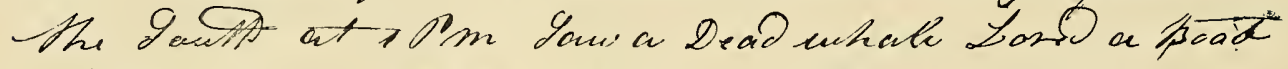

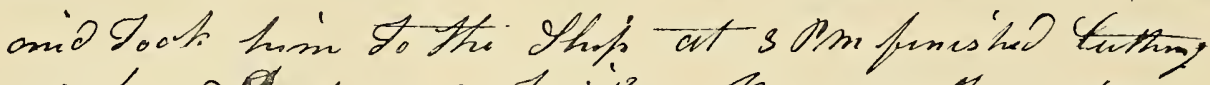

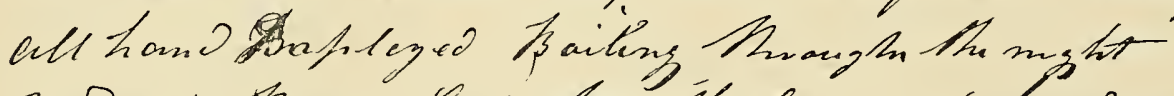

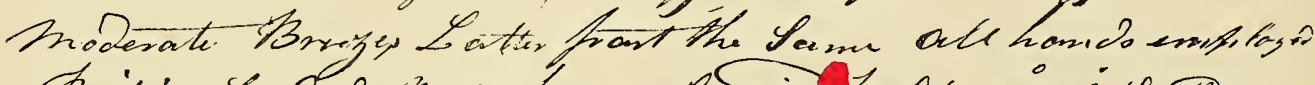

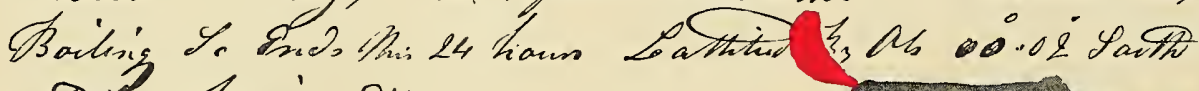
wostitiad Sa ming $\mathrm{SH}_{3} \mathrm{r}$ E Remarks on Wredmadeng

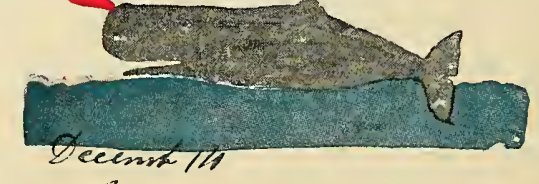

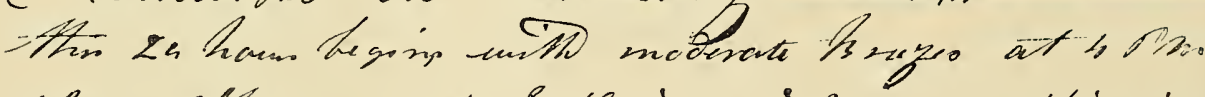

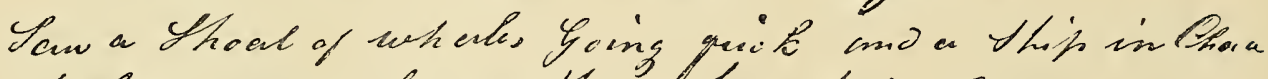
Thin Aviate font of this 24 trows torsk Trades

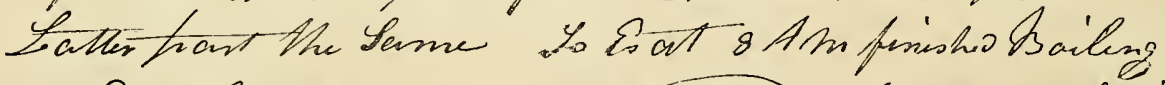
Io Snot Anis Bs th thithode to Ob. is oi 9

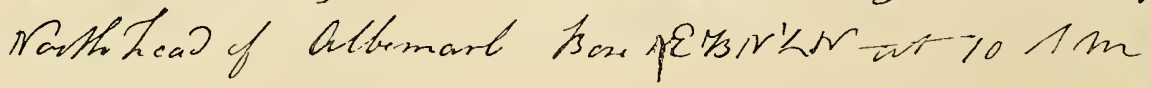

Thorerututex of the (Boil ổutstutess

Reproduction of an actual page from an old whaler's log book. When the whale was captured, a full drawing appears. When it was lost the tail is shown disappearing, as in lower right-hand corner. As a reminder of the romantic beginnings of the forerunner of the great oil
industry, whaling records possess a peculiar interest. 


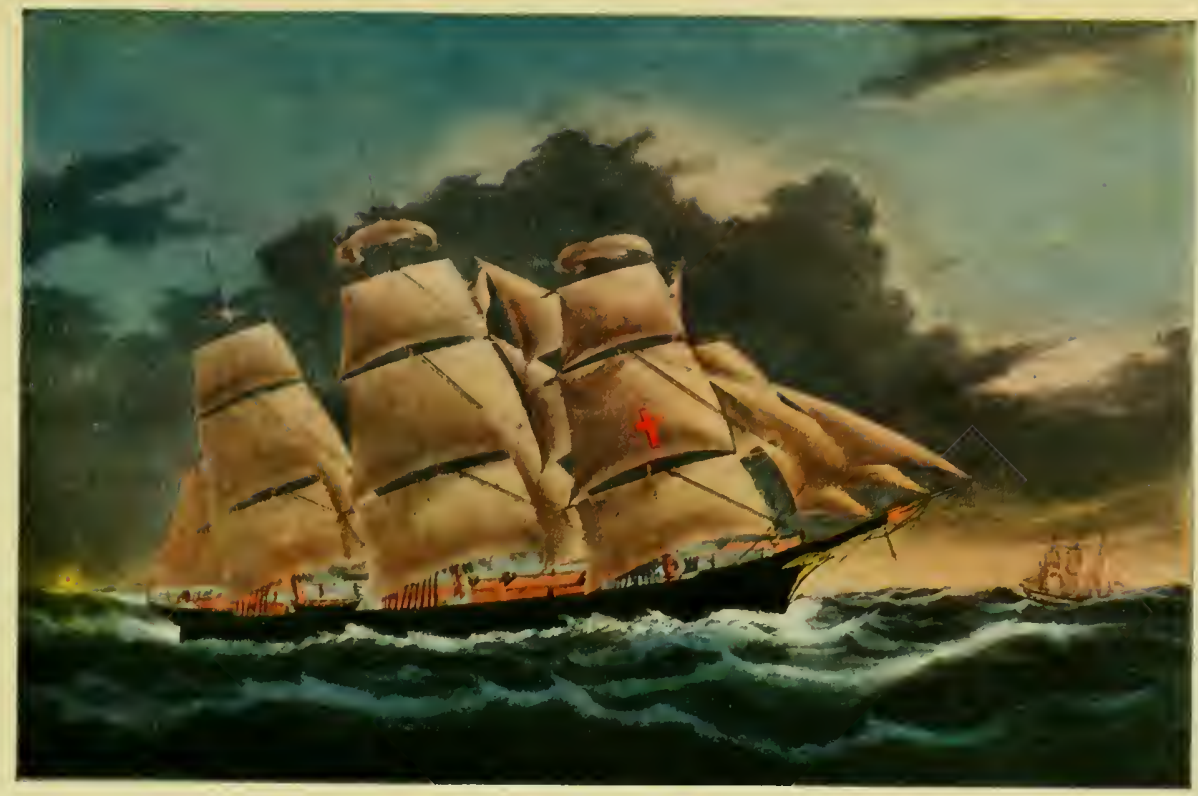

Tlye Dreatututught, 1853

Perhaps the most famous of all the I.iverpool Packet ships in the early 50 's. Commanded by Capt. Samuel Samuels, still remembered by many New Yorkers as one of the most celcbrated deep sea skippers sailing from this port. She was originally a Red Cross Packet Liner and later in the California trade. Few ships ever enjoyed such popularity. On Februart q th, 1859 , she logged 313 miles on a single day's run on a famous voyage from Liverpool to New York, completed in 13 days 8 hours. She was finally lost among the rugged cliffs and roaring breakers of Cape Horn. Her crew was rescued. She was a strikingly handsome ship and for years was the pride of the port. She was owned by Governor E. D. Morgan, Francis B. Cutting, Daniel Ogden and others. The majority of the New York fortunes prior to the Civil War grew out of shipping.

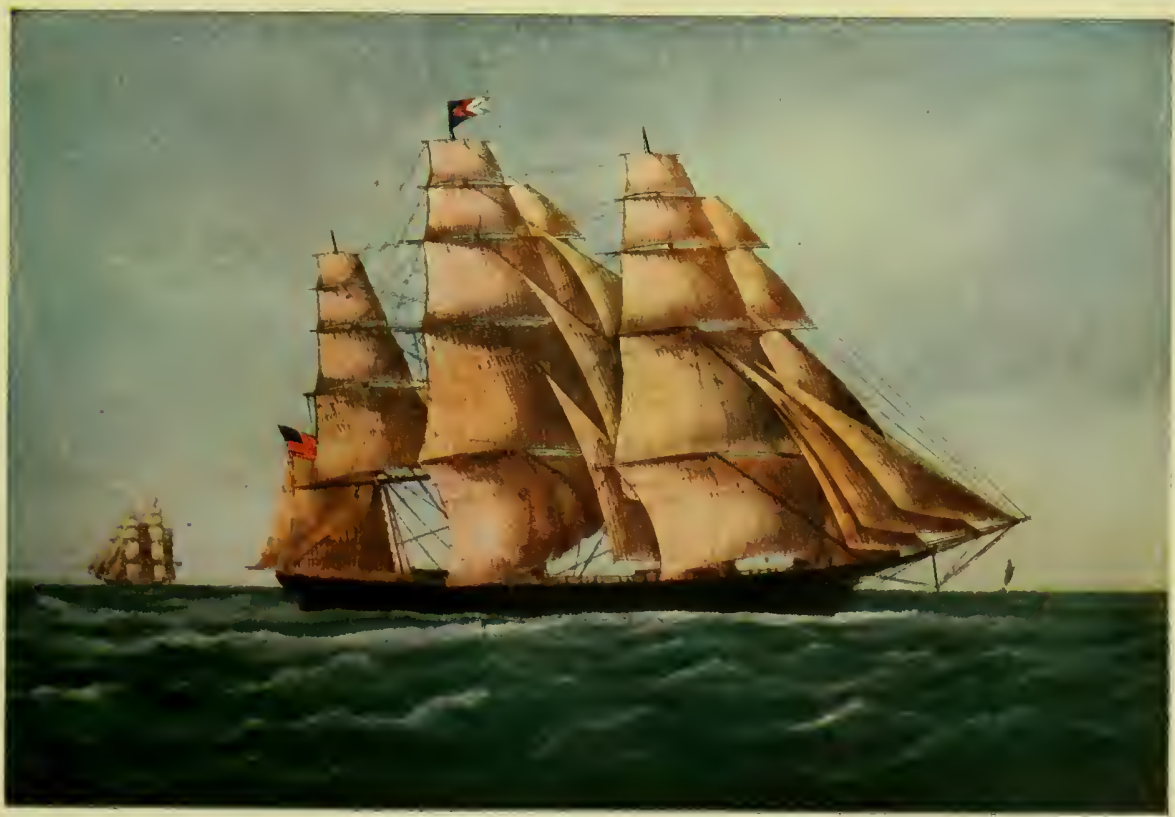

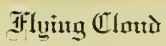

One of the crack Cape Horners, when the rush to California began in the "Roaring Forties." She was one of the square rigged beauties that made the fifteen thousand mile run from New York to the Golden Gate in the record time of eighty-nine davs, during which she logged 374 miles in twenty-four hours while steering northward and westward under topgallant sails after rounding Cape Horn-the fastest day's fun under steam or sail ever made up to that time. She was owned by Grinnell Minturn \& C C. 


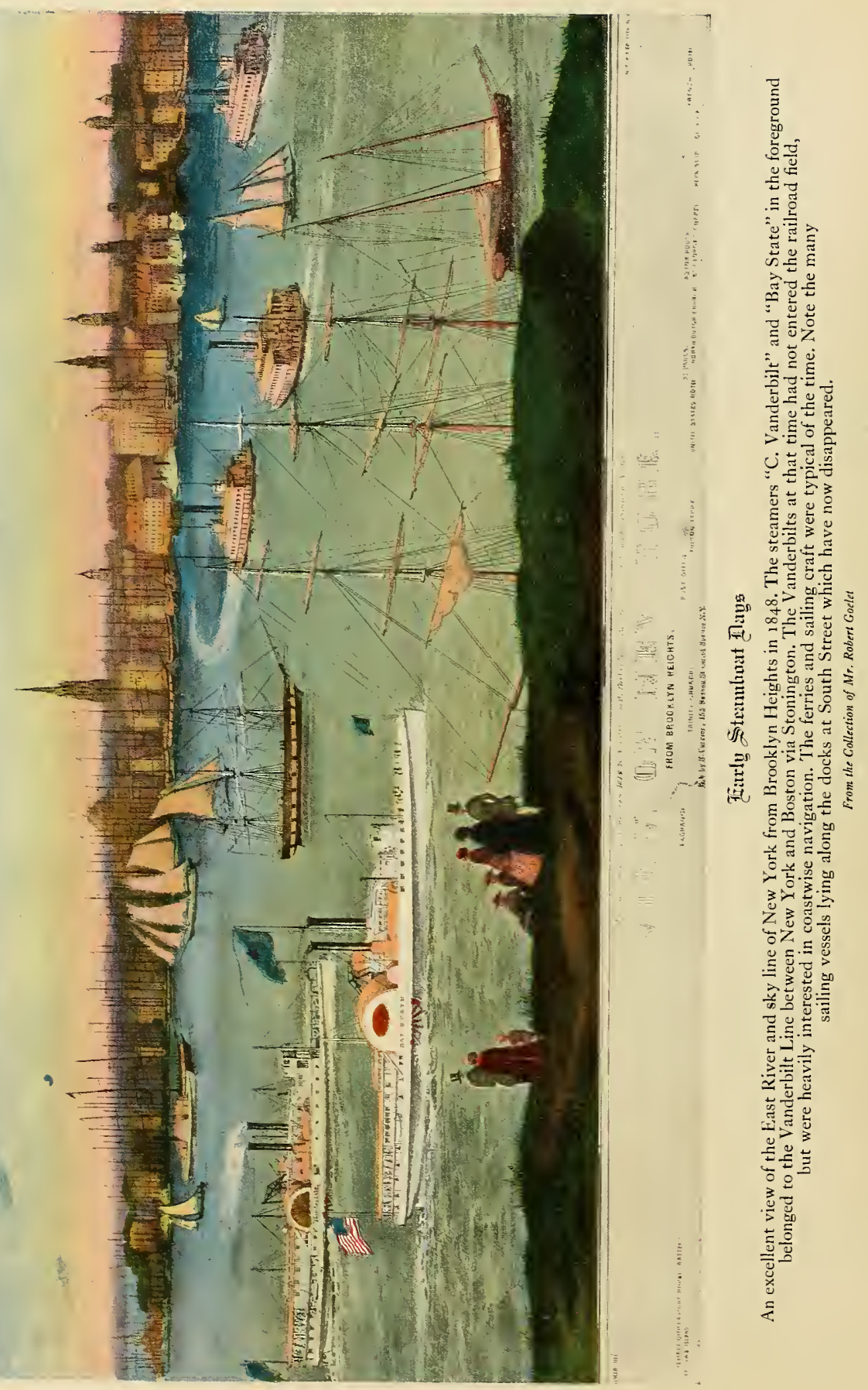




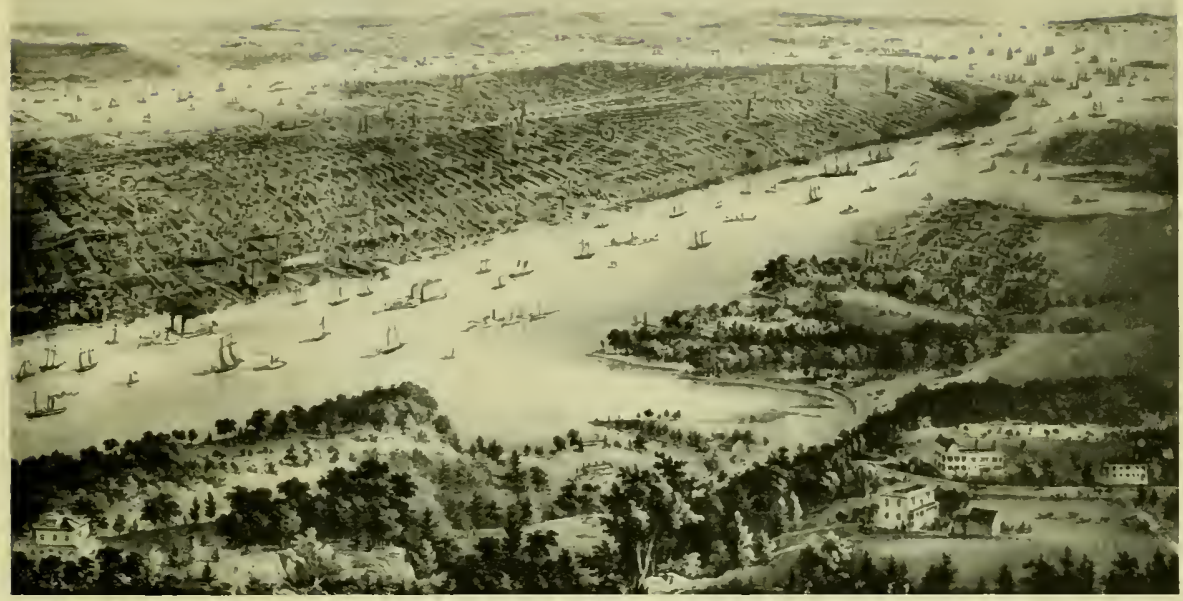

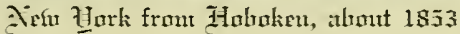

All of the sylvan scene on the Jersey shore (right of picture) is now covered with coal chutes, derricks, docks and ferries.

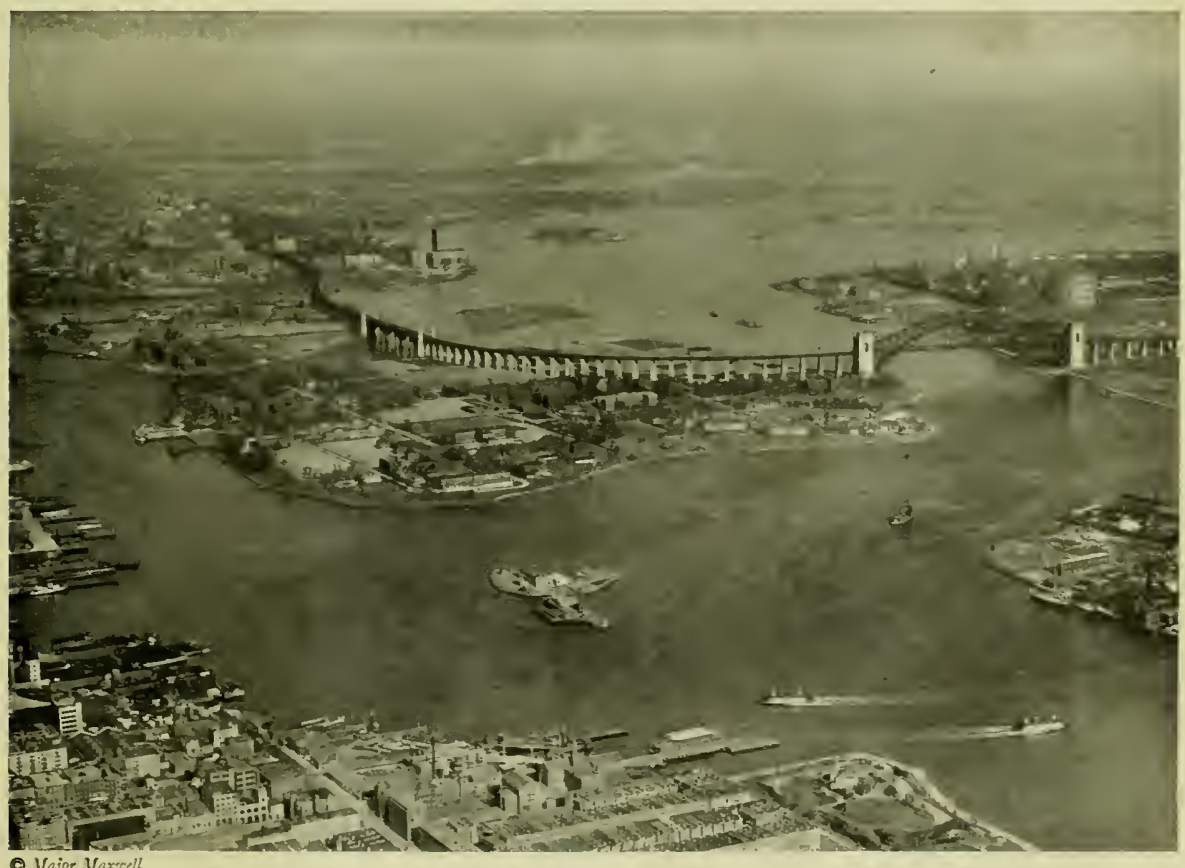

İell (5ate fliridg

The wonderful bridge built by the New Haven Railroad to pernit continuous transportation of trains to the South, eliminating former connection by ferry, by a connection with the Pennsylvania. The bridge is about five miles long and spans the East River near Hell Gate, crossing to Long Island. 


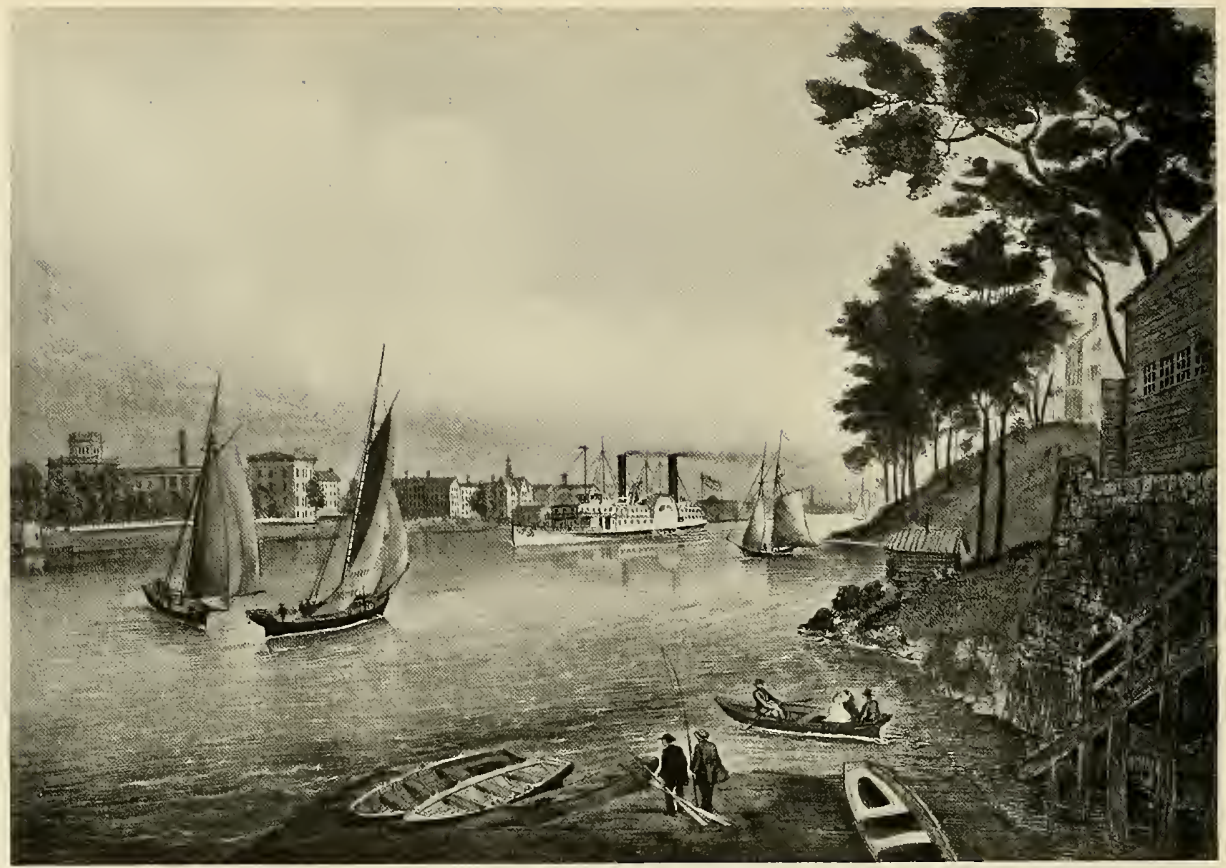

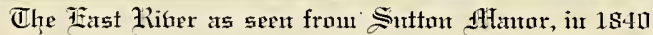

This locality is our newest fashionable section.

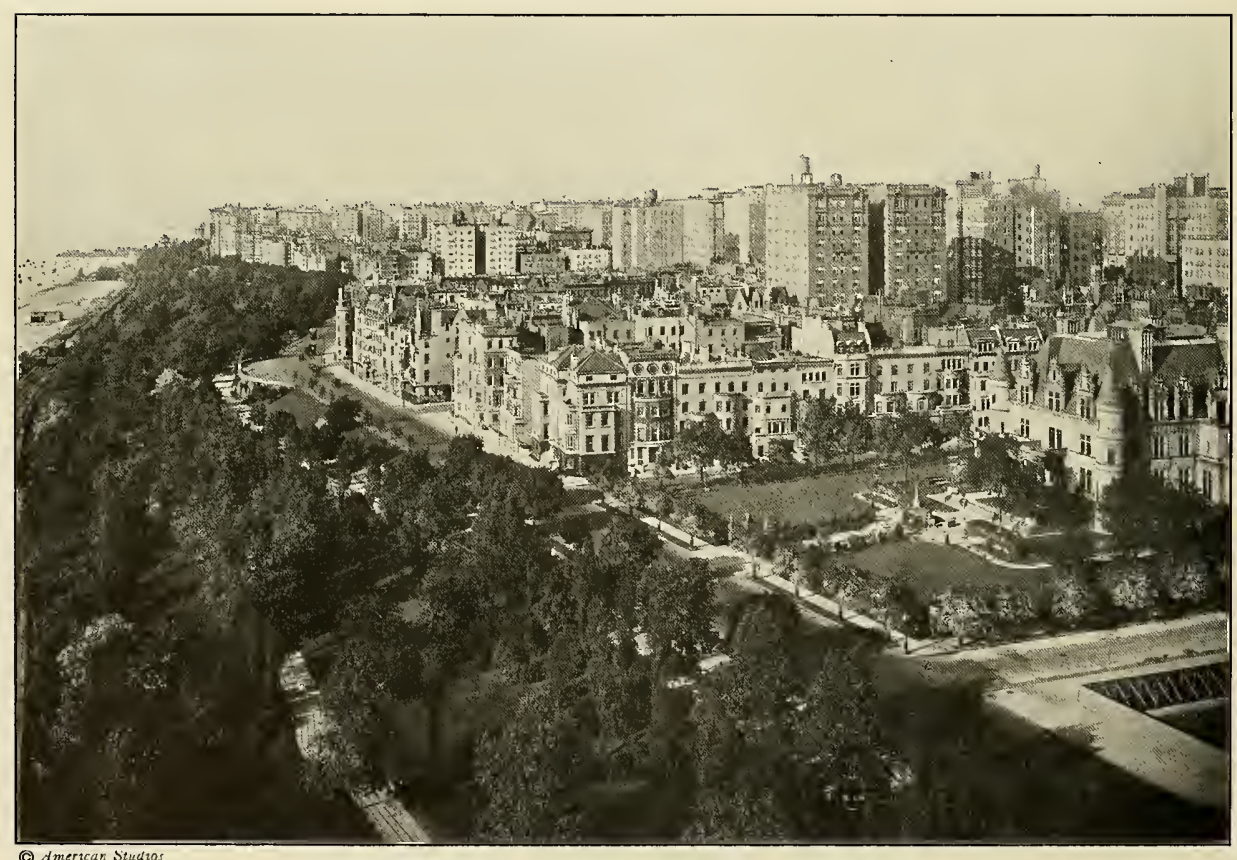

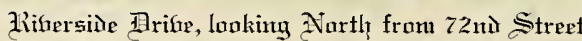

The building at the right with lawn in front is the residence of Mr Charles M. Schwas. 


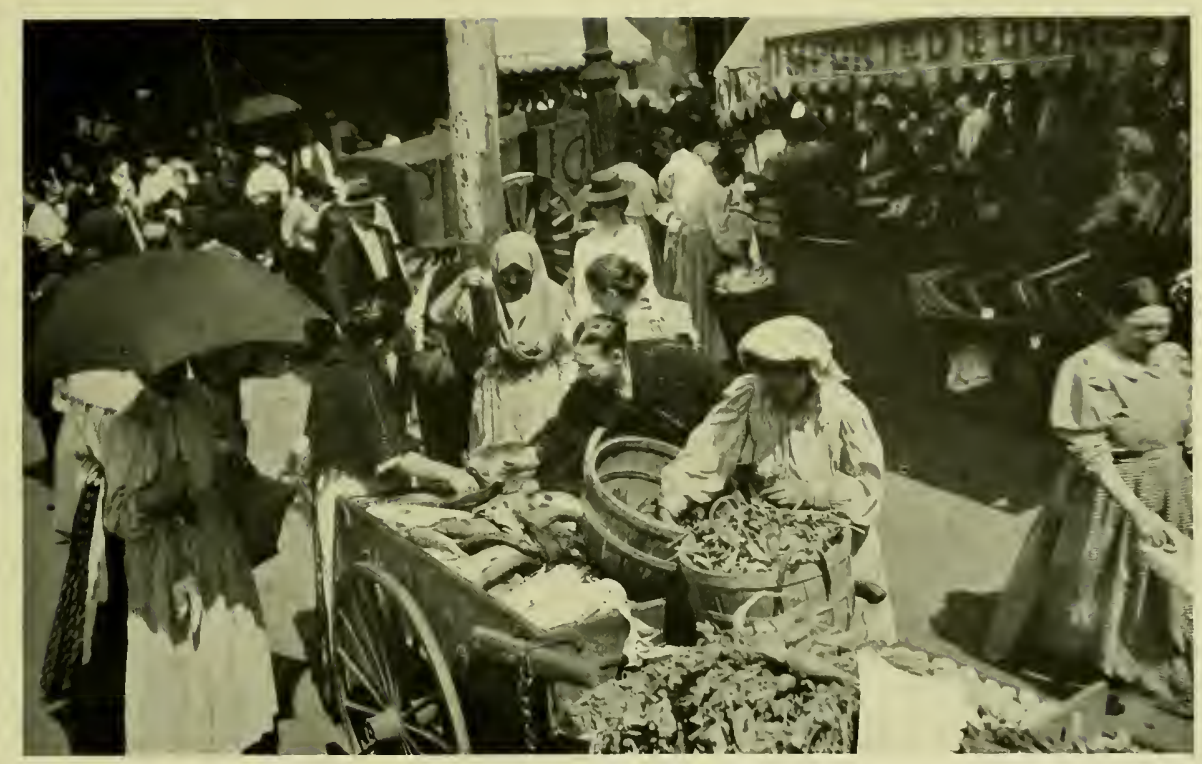

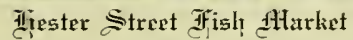

The great open air markets of the East Side. A view of the fish market in Hester Street. This is the type, little altered to this day, of the earliest markets in the world.

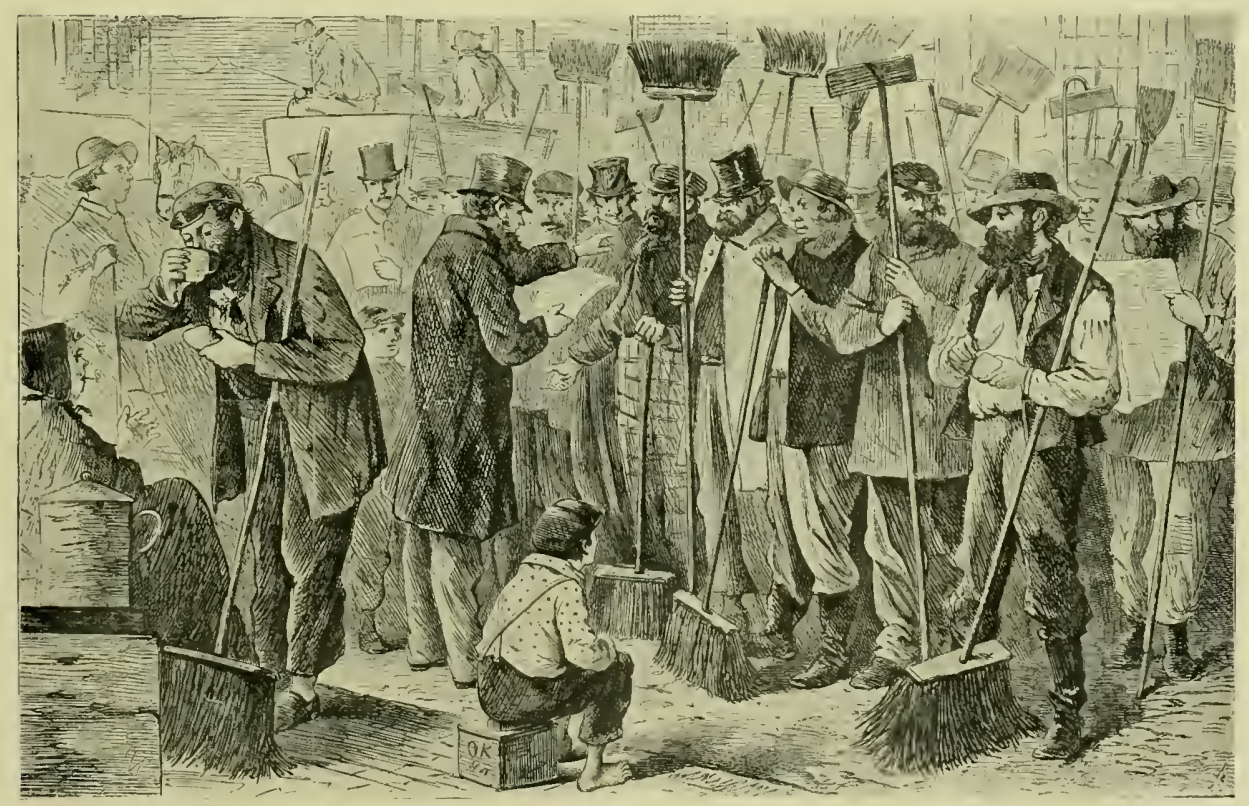

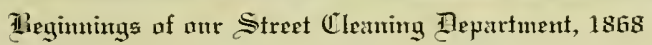
Calling the Roll. 


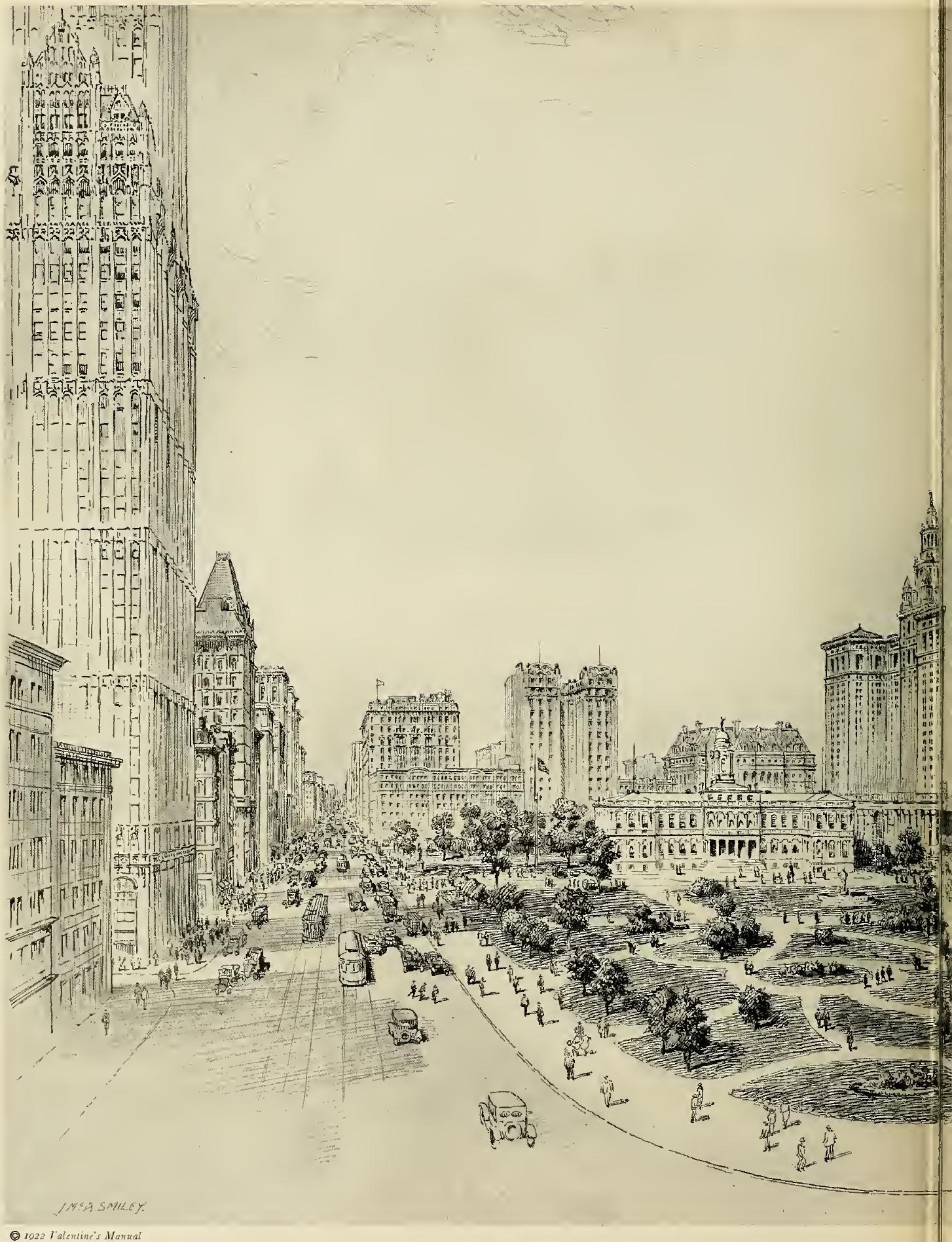




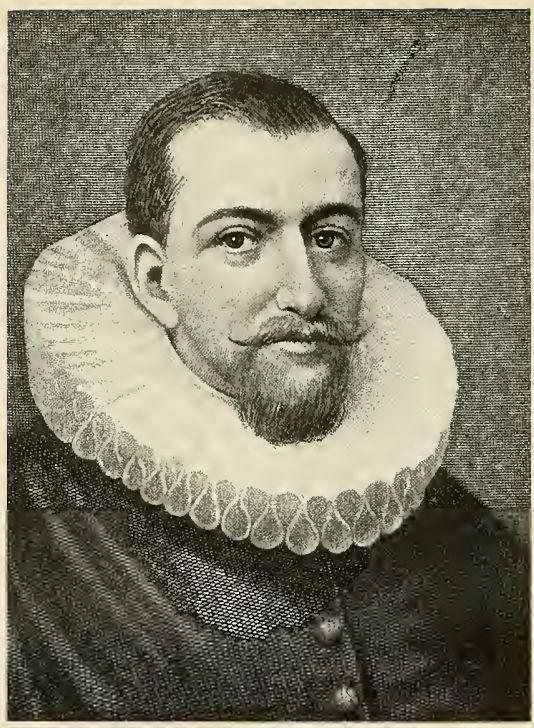

HENDRIK HUDSON

The first Navigator to land on Manhattan Island and to sail up the river which now bears his name. In a subsequent voyage Hudson was turned adrift in an open boat, in the Arctic Seas by mutinous sailors and never heard of again. He was born in London. Date of birth and death both unknown.

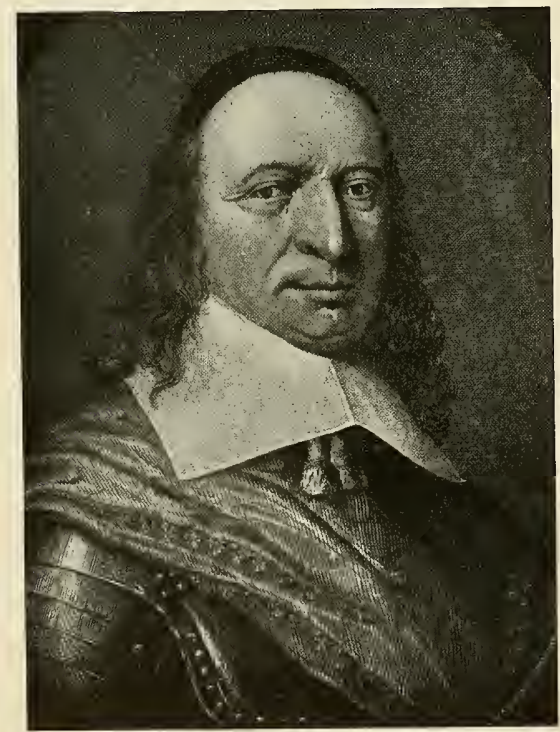

PETRUS STUYVESANT

Last and greatest of the Dutch Governors. $\mathrm{He}$ is buried in St. Mark's Church. Fleventh Street and Second Avenue, which was erected on the site of the private chapel which stood on his farm. The land for St. Mark's was given to the Dutch Church by his wife, on condition that his grave be preserved. From the painting by Van Dyck, now in possession of the New York Historical Society.

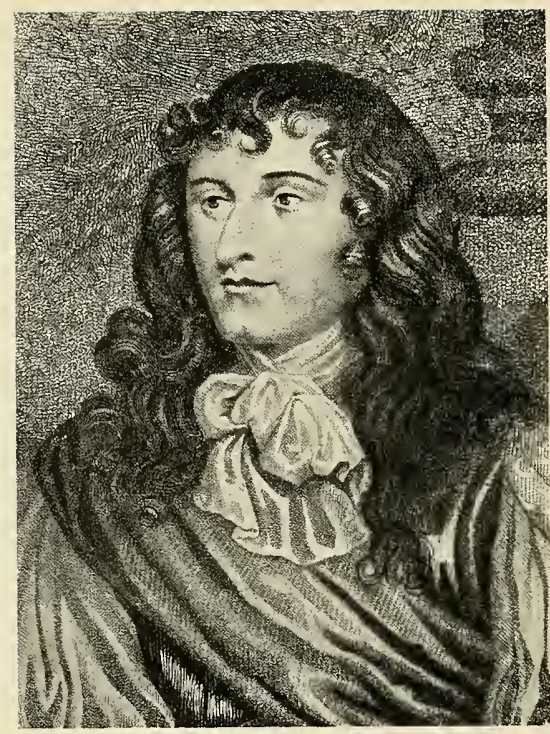

JAMFS, DUKE OF YORK AND ALBANY

After whom our City and the capital of our State, was named. On the death of Charles II the Duke succeeded to the throne as James II. A map shown elsewhere in these pages, known as "The Duke's Plan" is said to have been prepared by him, based on surveys by Nicolls, and is the first authentic drawing of New York as it appeared when captured by the Englich (I664). From a painting by Sir Peter Lely, in the possession of the Duke of Queensbury.

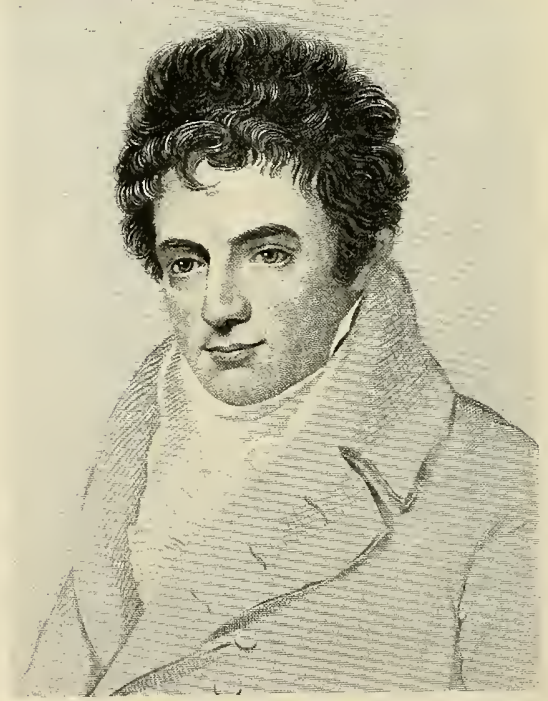

ROBERT FULTON, 1765-1815

Inventor of the Steamboat. The Clermont, the first successful vessel to be propelled by steam, made the voyage from New York to Albany at about five miles an hour (1807). Fulton was also successful as an architect. He studied under the great painter, Benjamin West, a neighbor of his in Lancaster, where Fulton was born, but who early removed to England. Fulton died in a house at the rear of No. I Broadway, 1815 . 
The Ciarroll Cilub

Built as the First Women's Club building in New York, the Colony Club on Madison Avenue. Now the Carroll Club, a business women's club, a gift to the Catholic young women of this city, by Mrs. Nicholas F. Brady in memory of her mother; May Carroll Garvan.

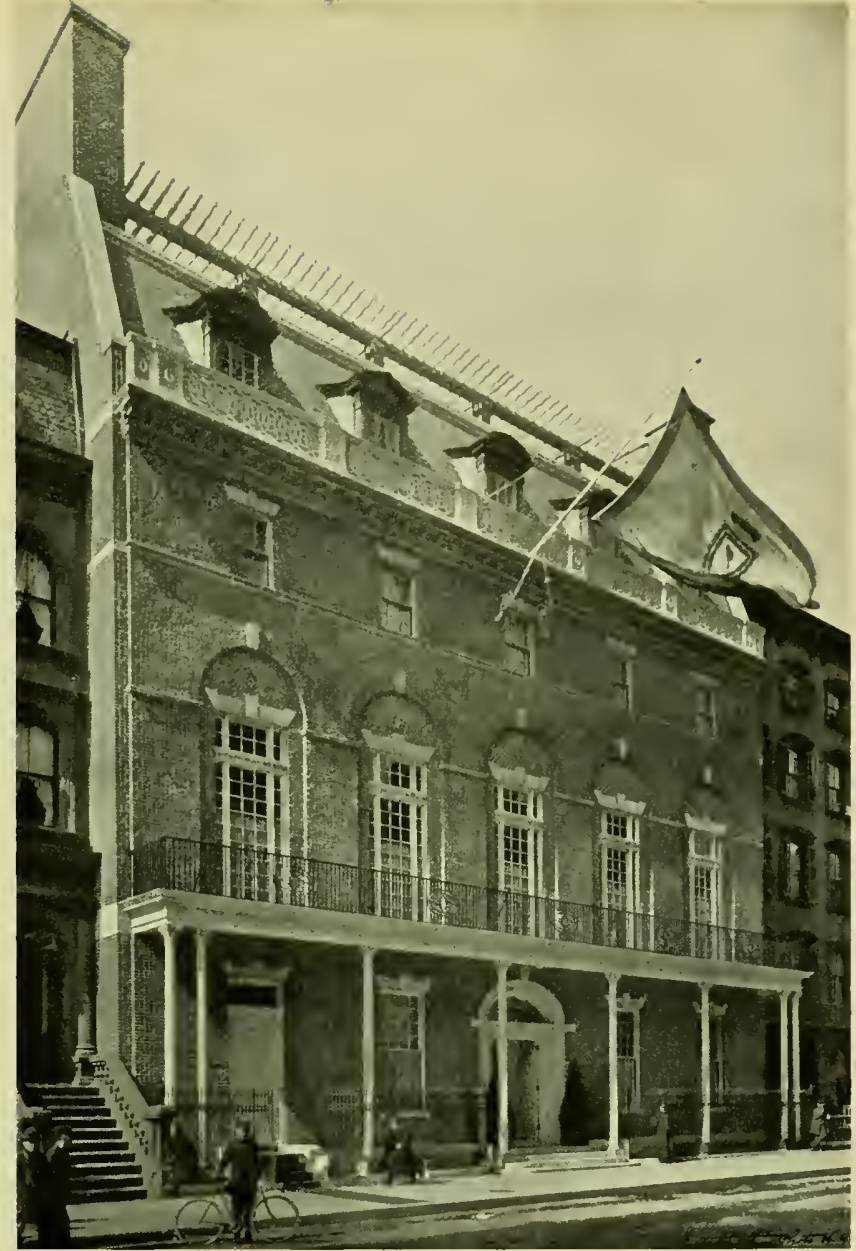

Tfiftl Âtrente, loaling X̀orth from 54 th to 59 th Street, 1890

Steeple of St. Thomas' Church in centre. The quiet atmosphere of this residential street in the nineties is well indicated in the picture opposite. 


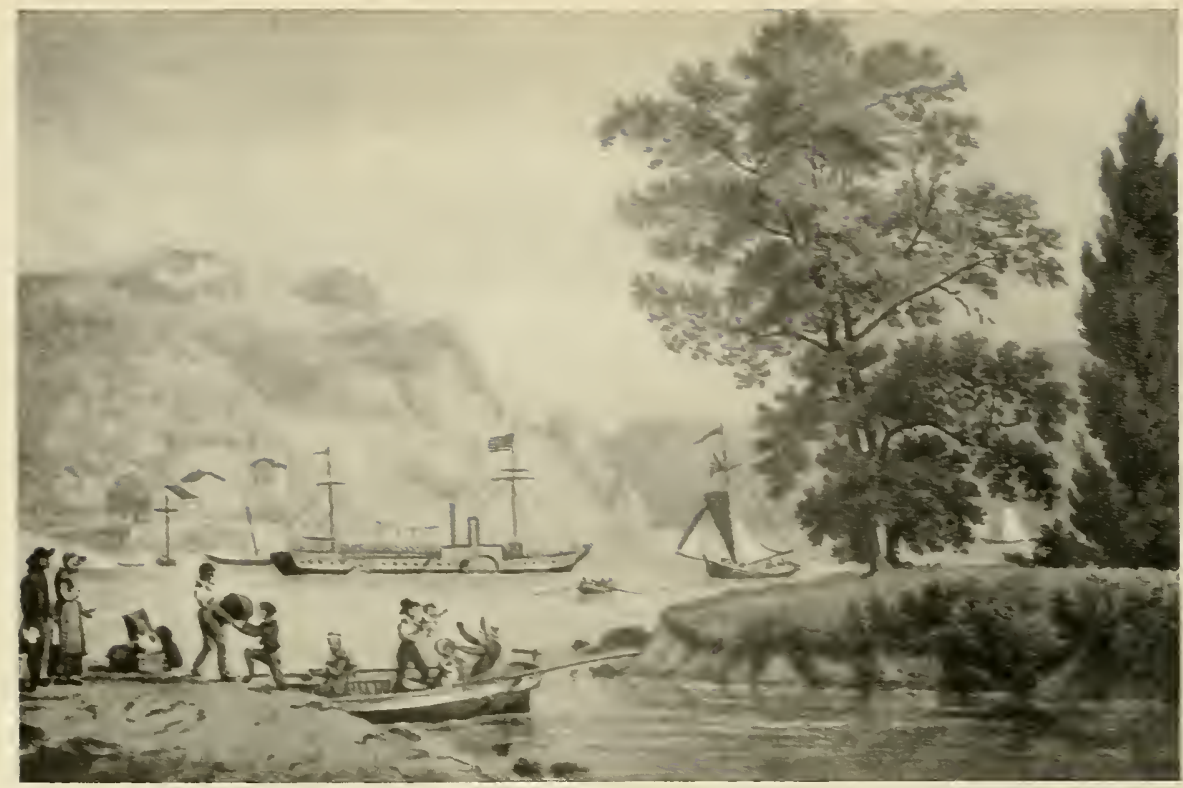

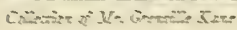

The Firat \$tumahty

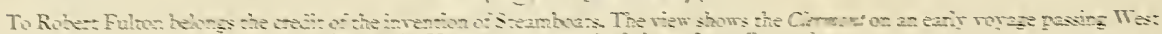

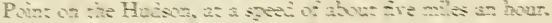

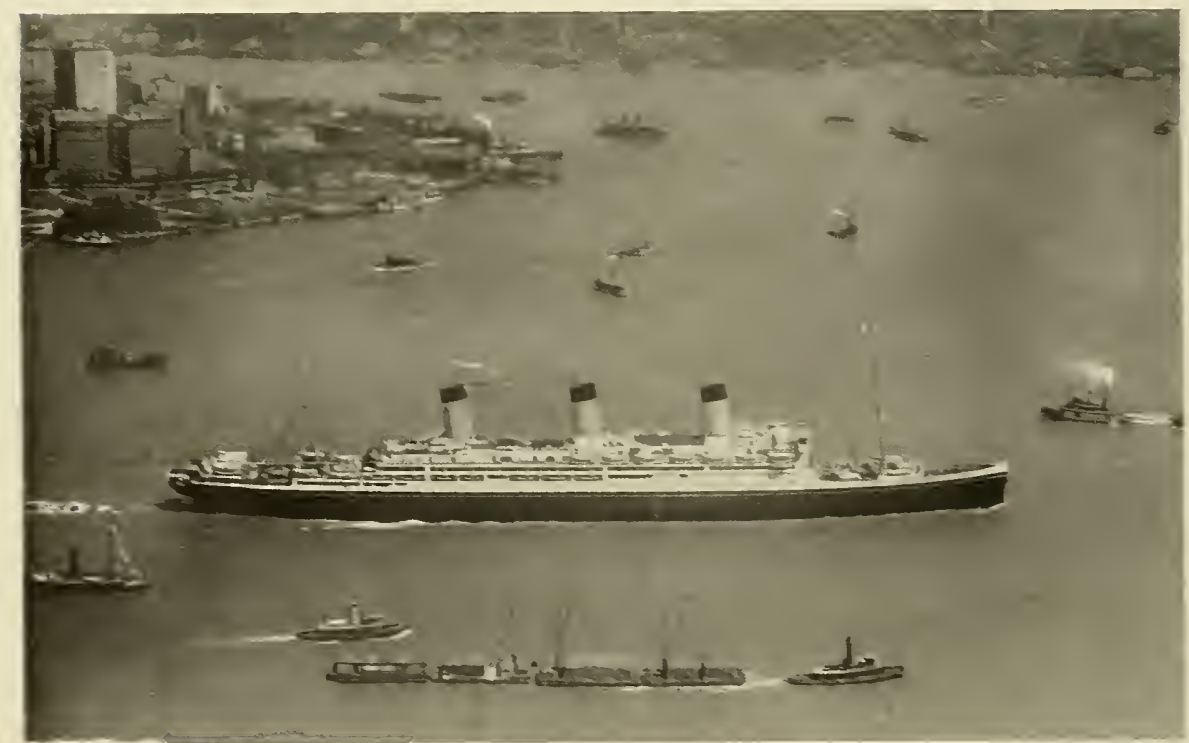

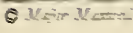

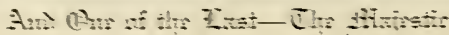

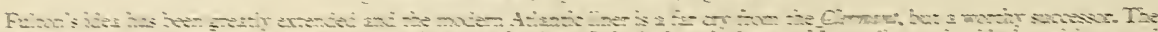

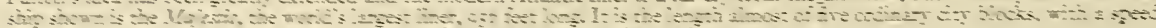

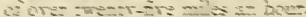




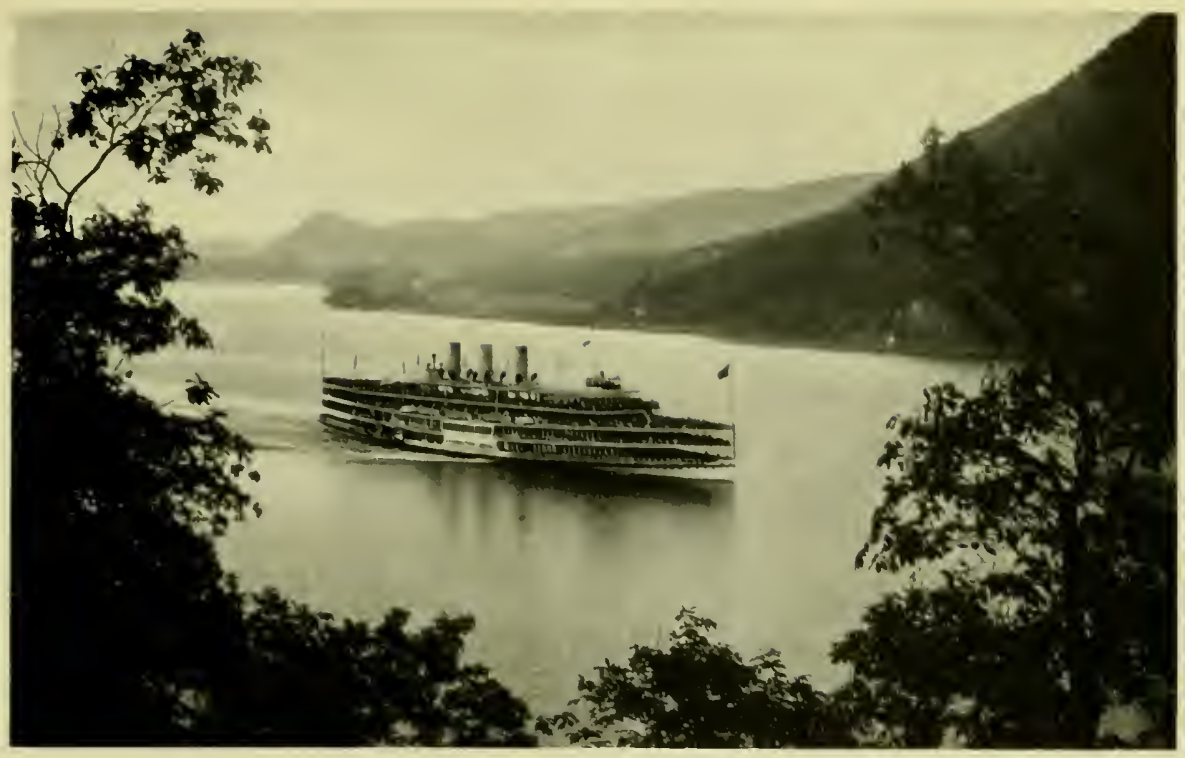

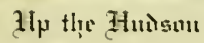

On the way to West Point. Steamer Washington Iring in the Highlands of the Hudson.

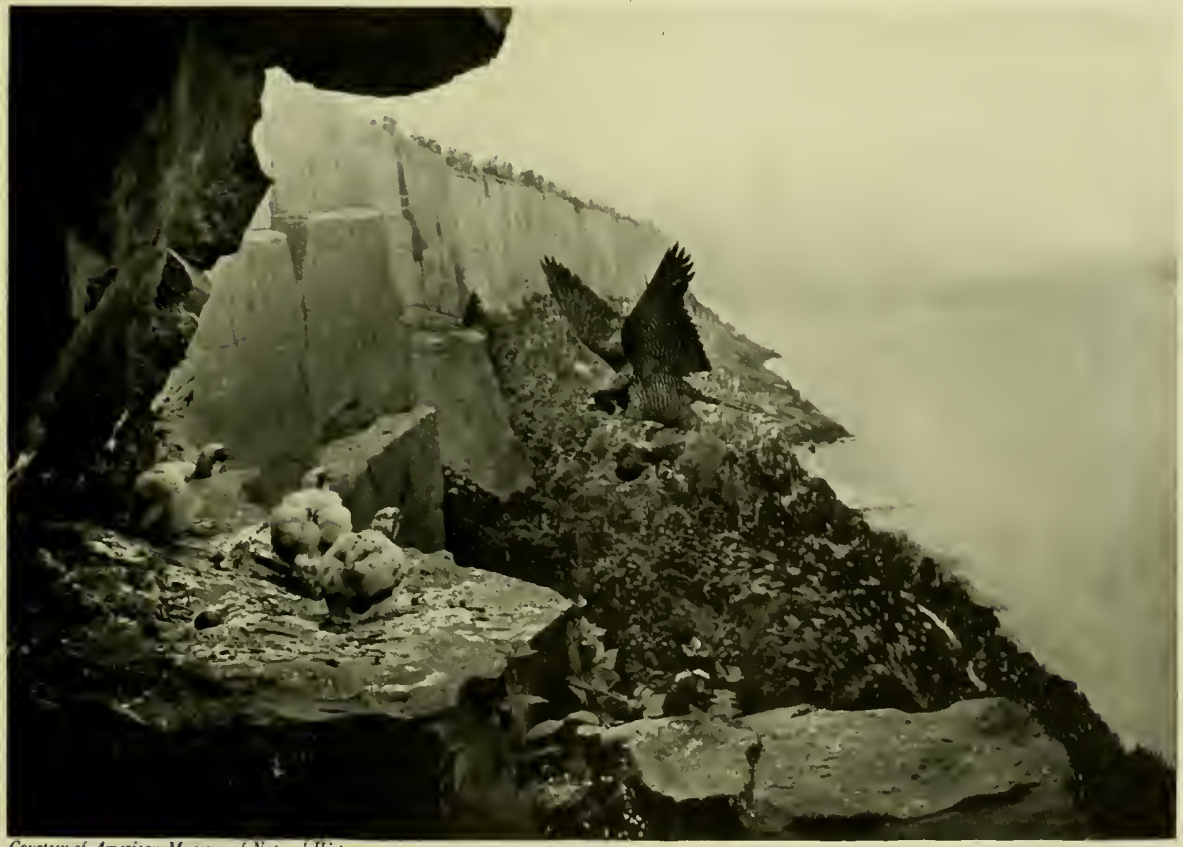

Courtesy of American Museum of $N$ atural History

Thye Jalisatirg

Birds of prey build their nests around the crags of the Palisades. A scene on the way to West Point. 


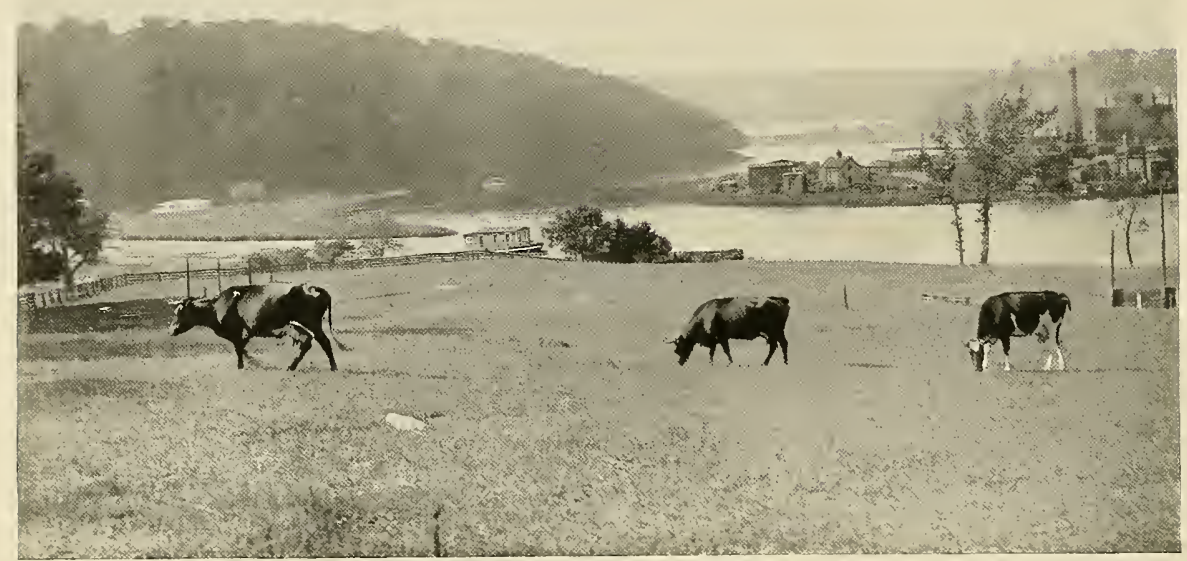

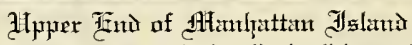

The northern end of Manhattan Island still retains all its bucolic simplicity, and presents a striking contrast to the cloud-piercing structures that mark its southern end.

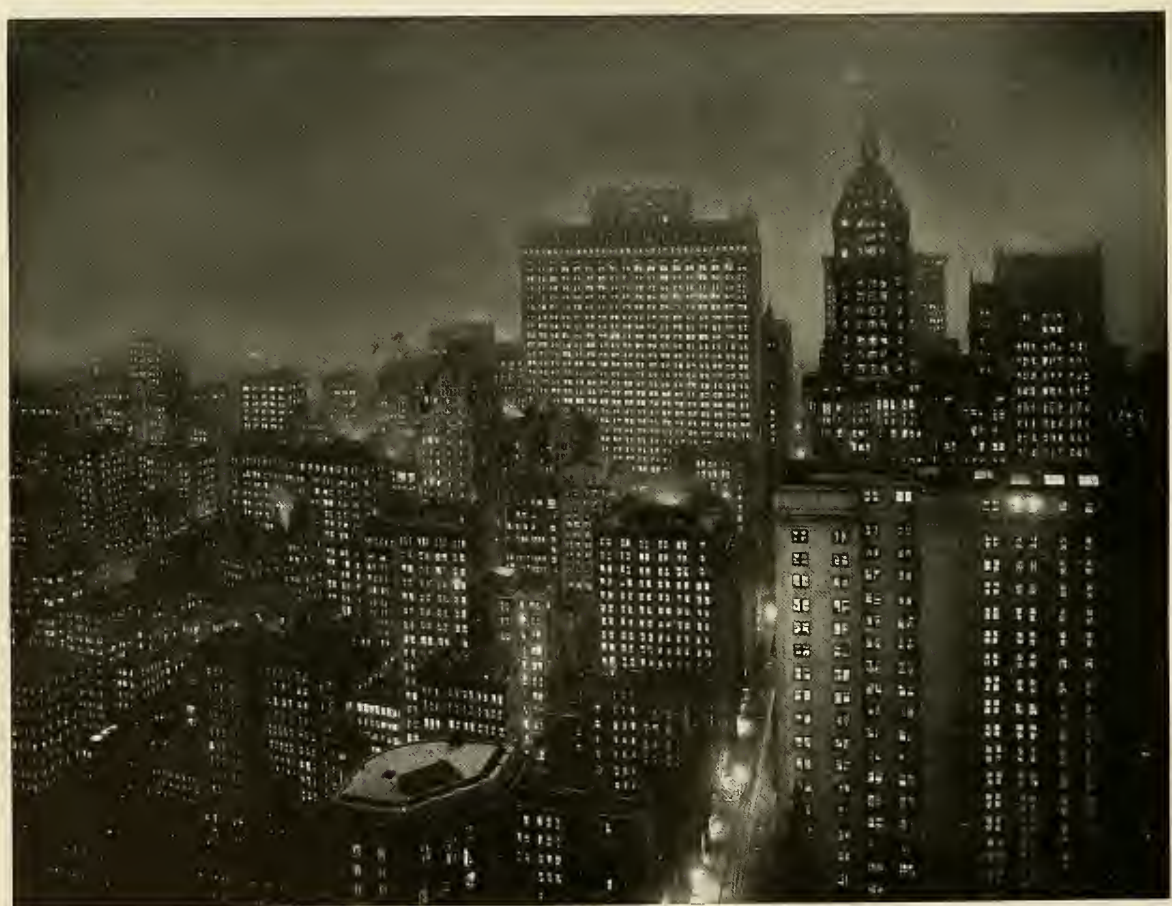

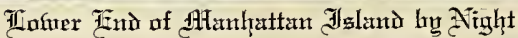

Few more dramatic contrasts can be imagined than between the extreme upper and lower ends of Manhattan Island as depicted in the views presented on this page. 


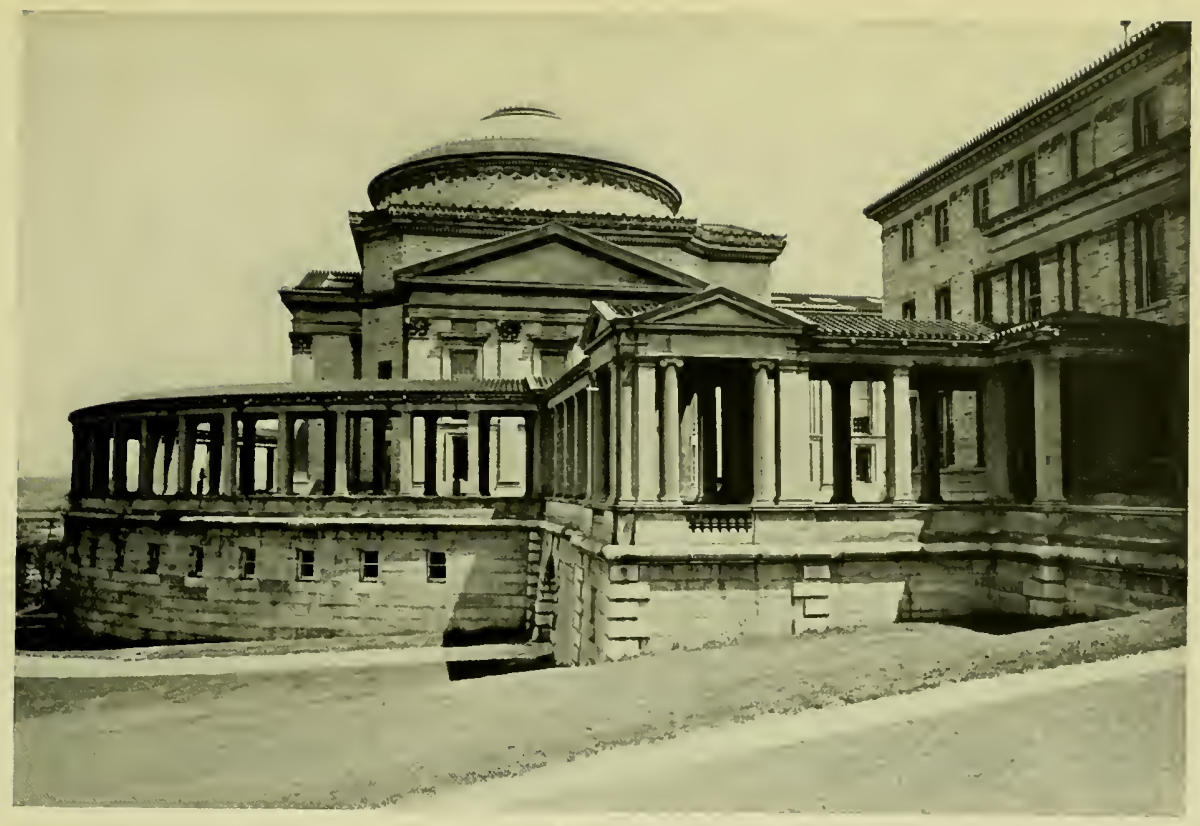

The Hall of Trame

The celebrated Hall of Fame presented by Helen Gould, in New York University at Iniversity Heights.

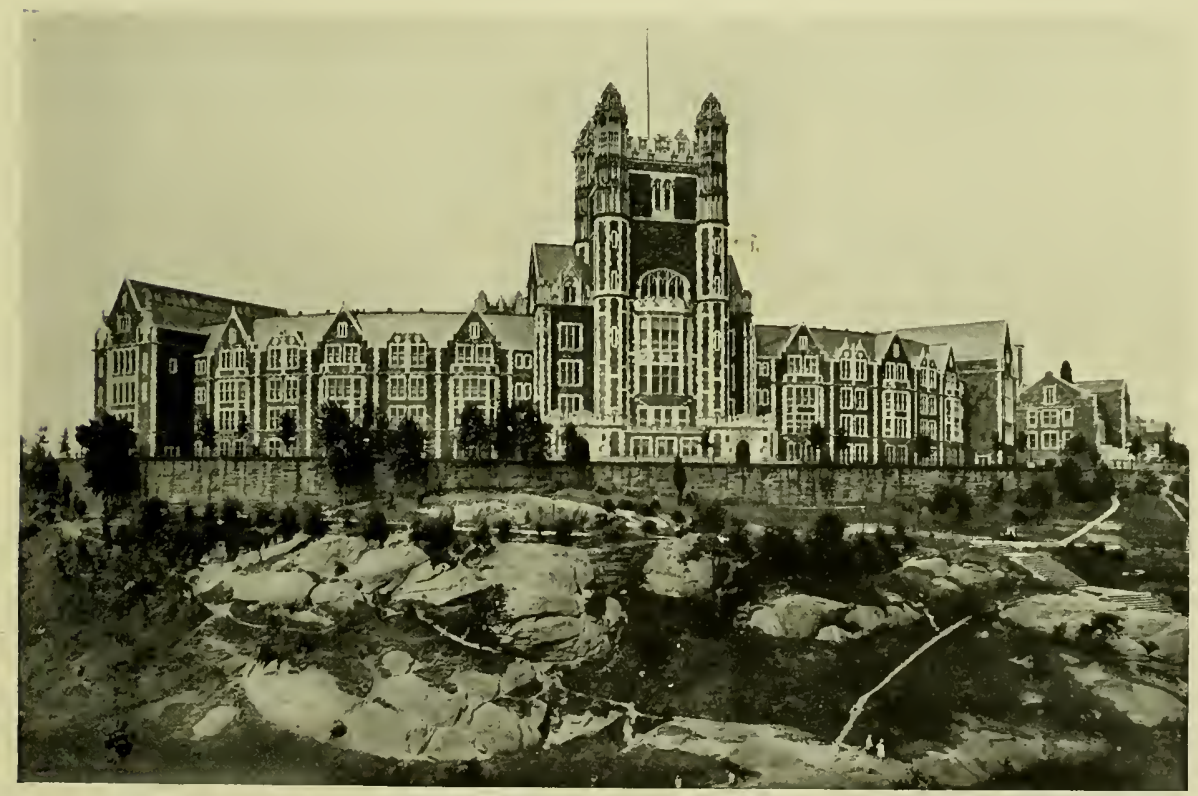

(Tity College

The College of the City of New York, originally known as the "Free Academy." The largest free institution for higher education maintained by any city in the world. Enrollment over 17,000 . 


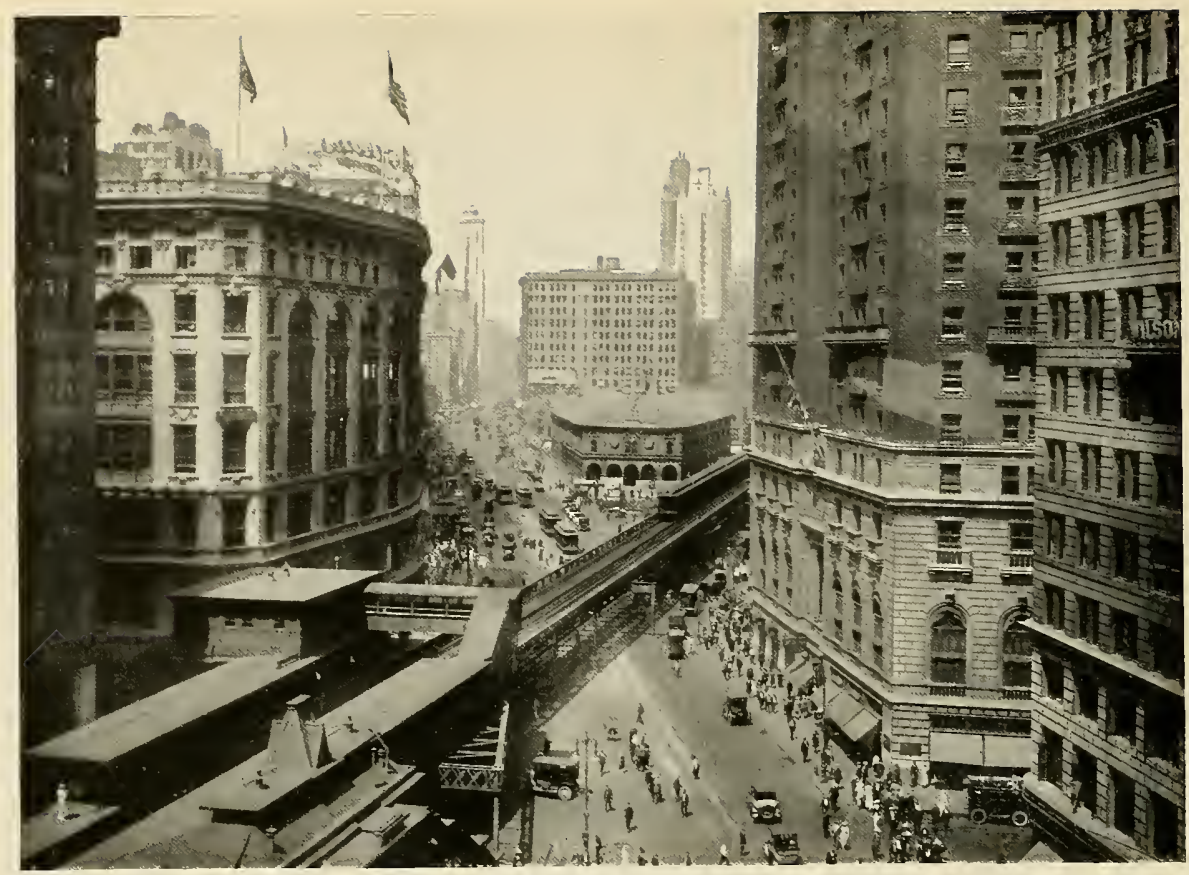

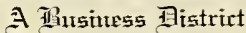

$3+$ th Street and Sixth Avenue showing Gimbel's, Macy's, Herald Building, and McAlpin Hotel. The Times Building is in the background to the left.

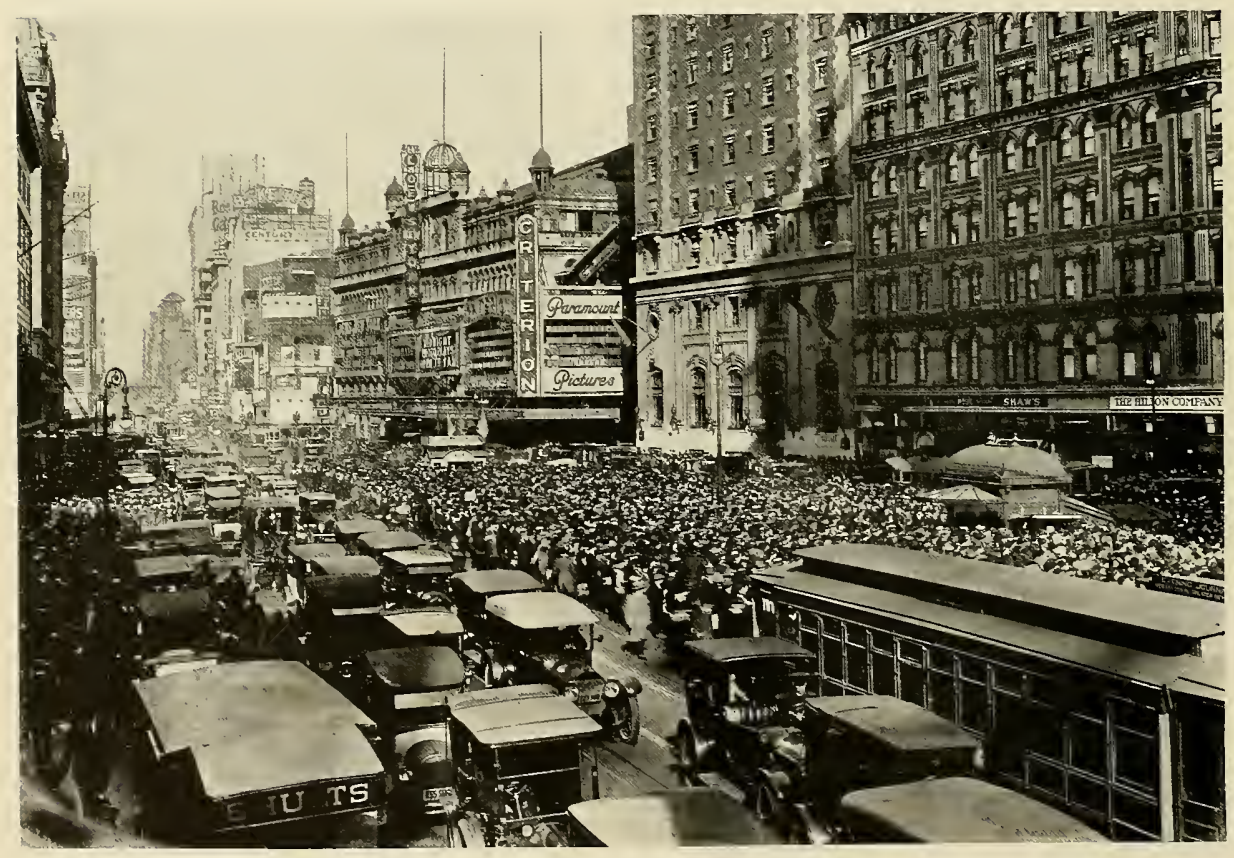

The The lyatritat 国istrixt

Looking up town on Broadway from 42 nd Street to 5oth Street showing the immense crowds that gather on Saturday afternoons and evenings to attend the seventy odd theatres in the neighborhood. 


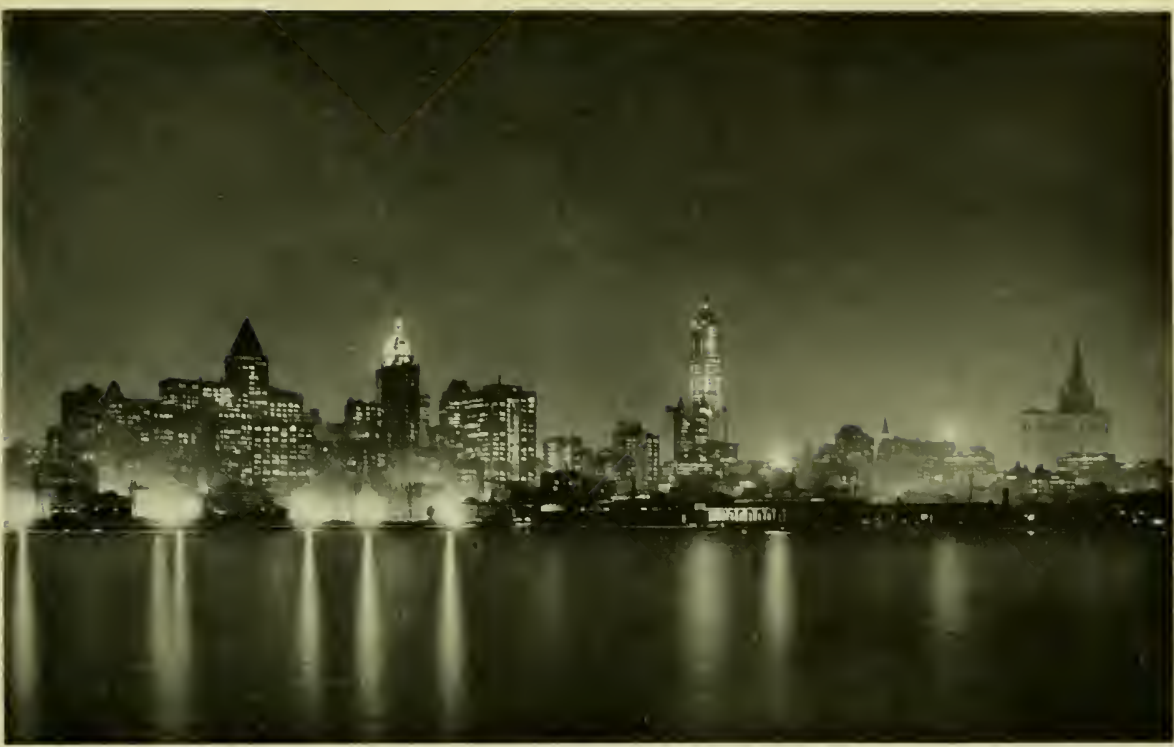

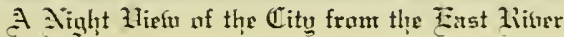

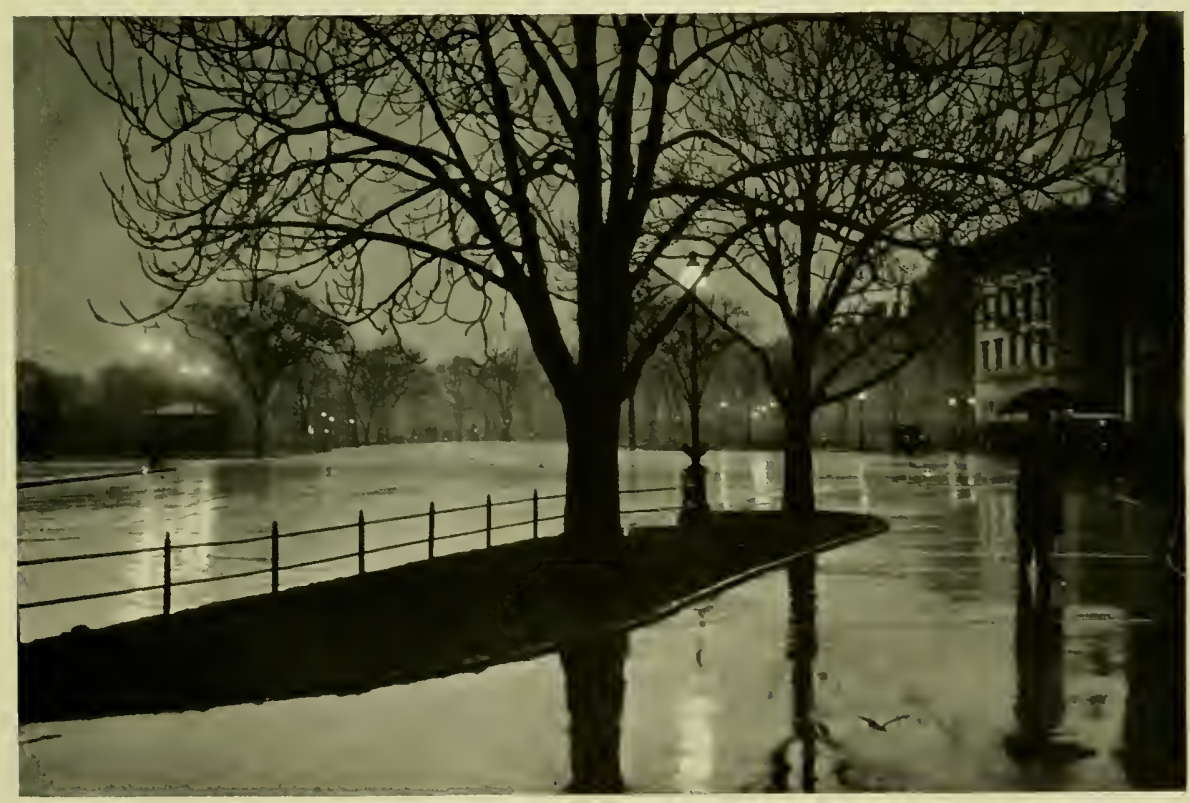

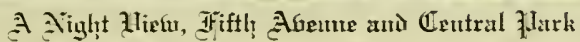




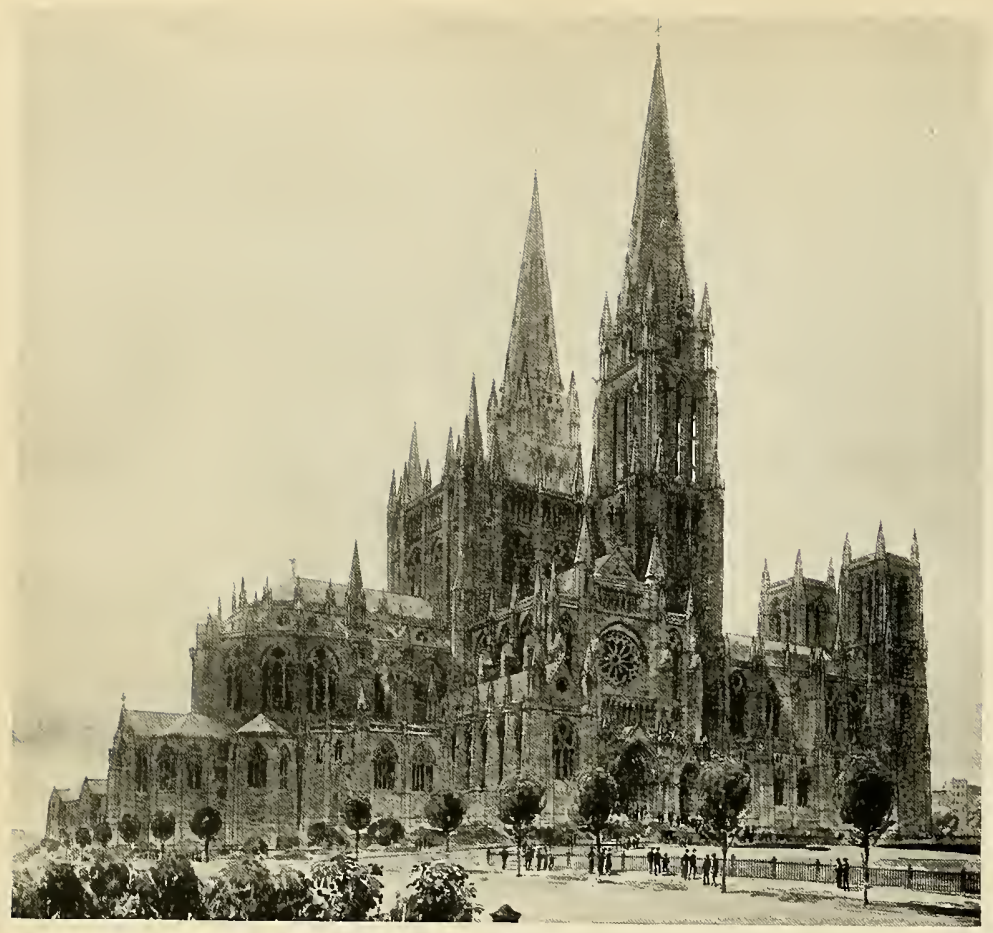

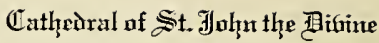
The Cathedral of St. John the Divine on Morningside Heights, as it will appear when completed.

St. 昍atrick's (Tatlịedral

St. Patrick's Cathedral on Fifth Avenue between 50 th and 5 ist Streets.

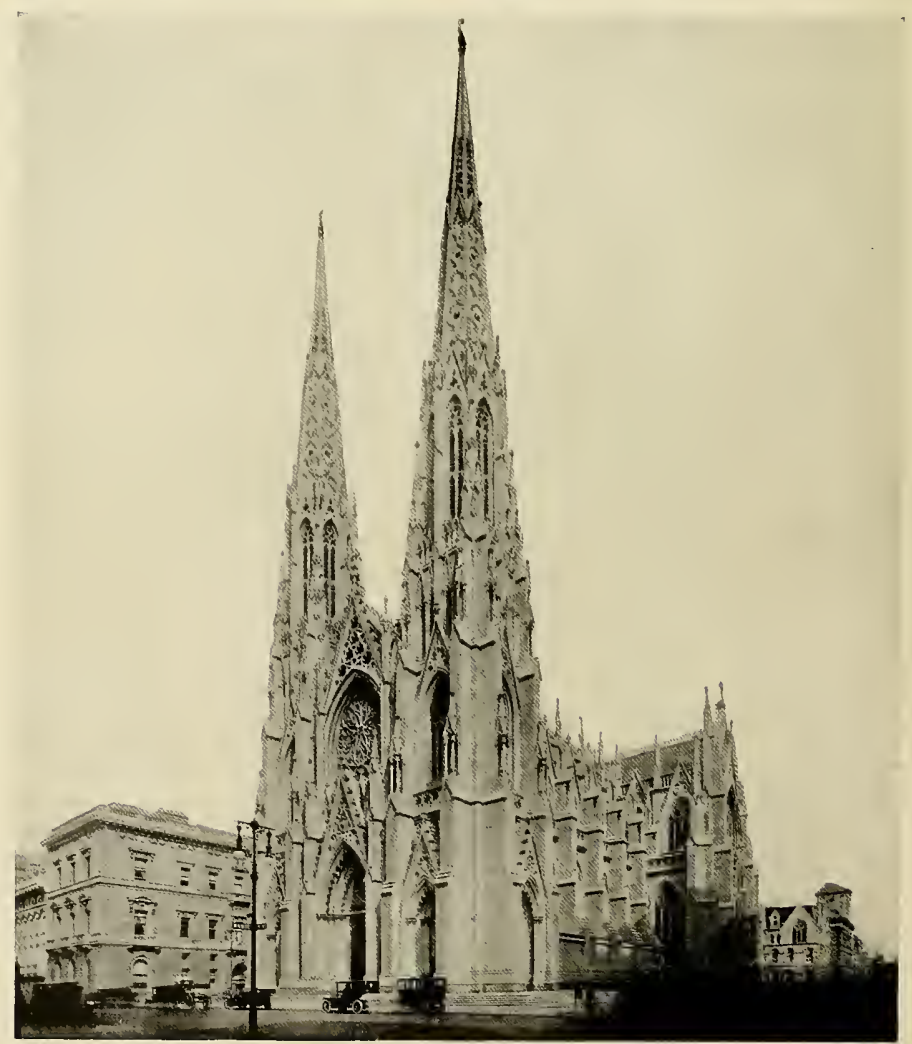




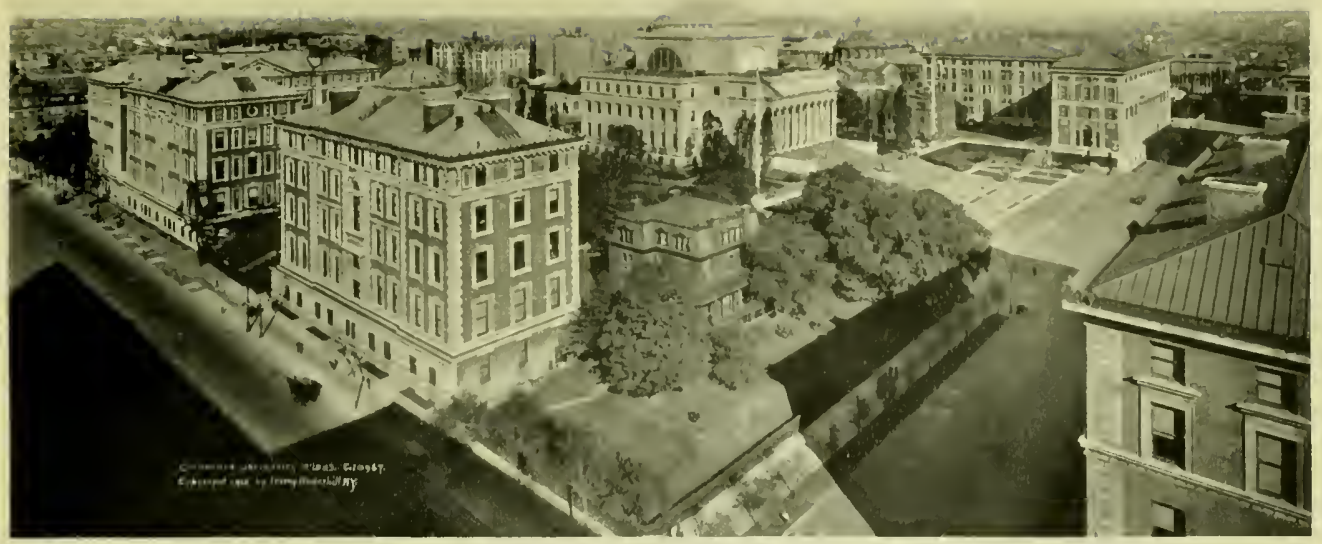

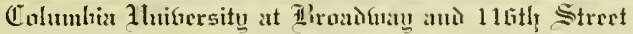

The service of the great popular universities of the Middle Ages is paralleled lyy this institution with its enrollment of 32,050 . Fistablished as hings College in $175+$. The College grounds cover many blocks.

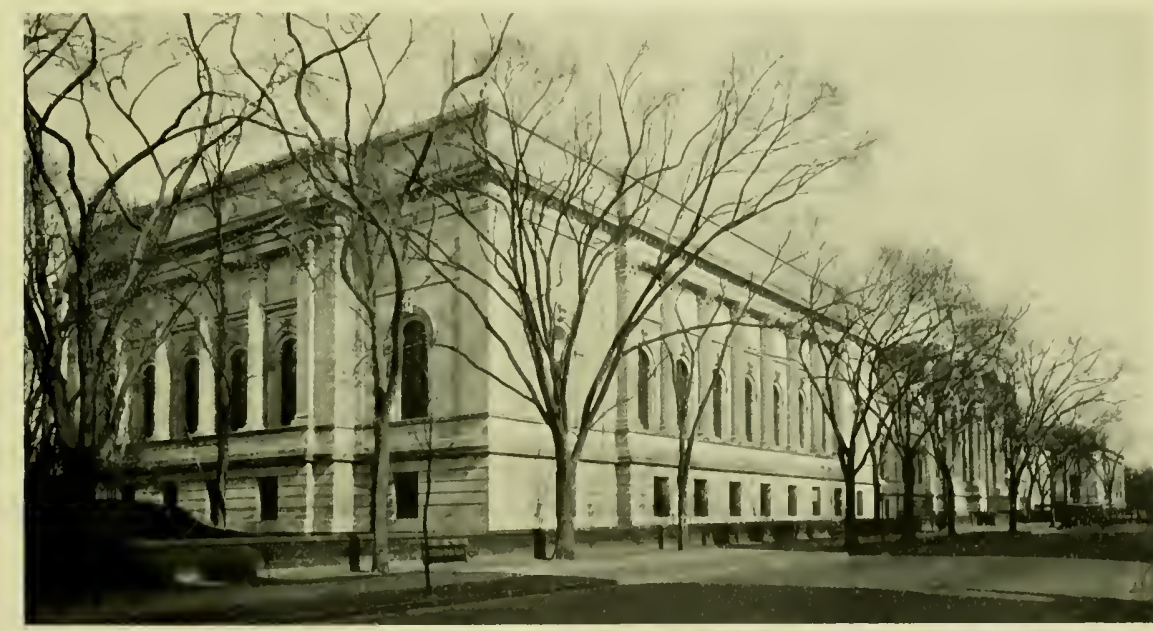

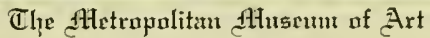

Fifth Avenue and 82nd Street. One of New York's greatest attractions for the visitor.

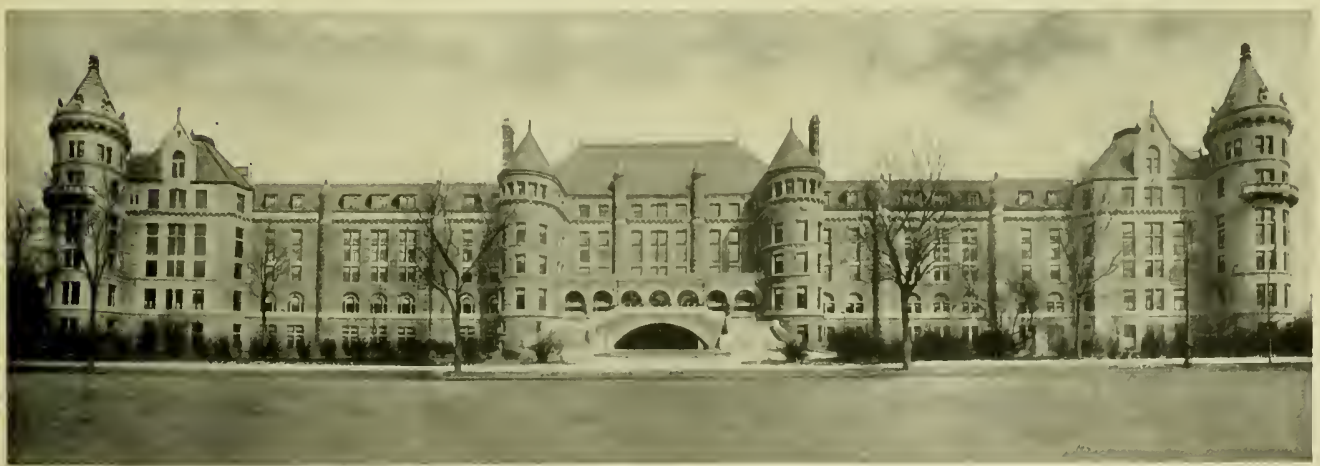

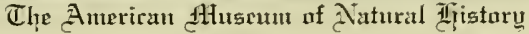

At 77 th Street and Central Park West. A marvelous collection of everything pertaining to its special field. 


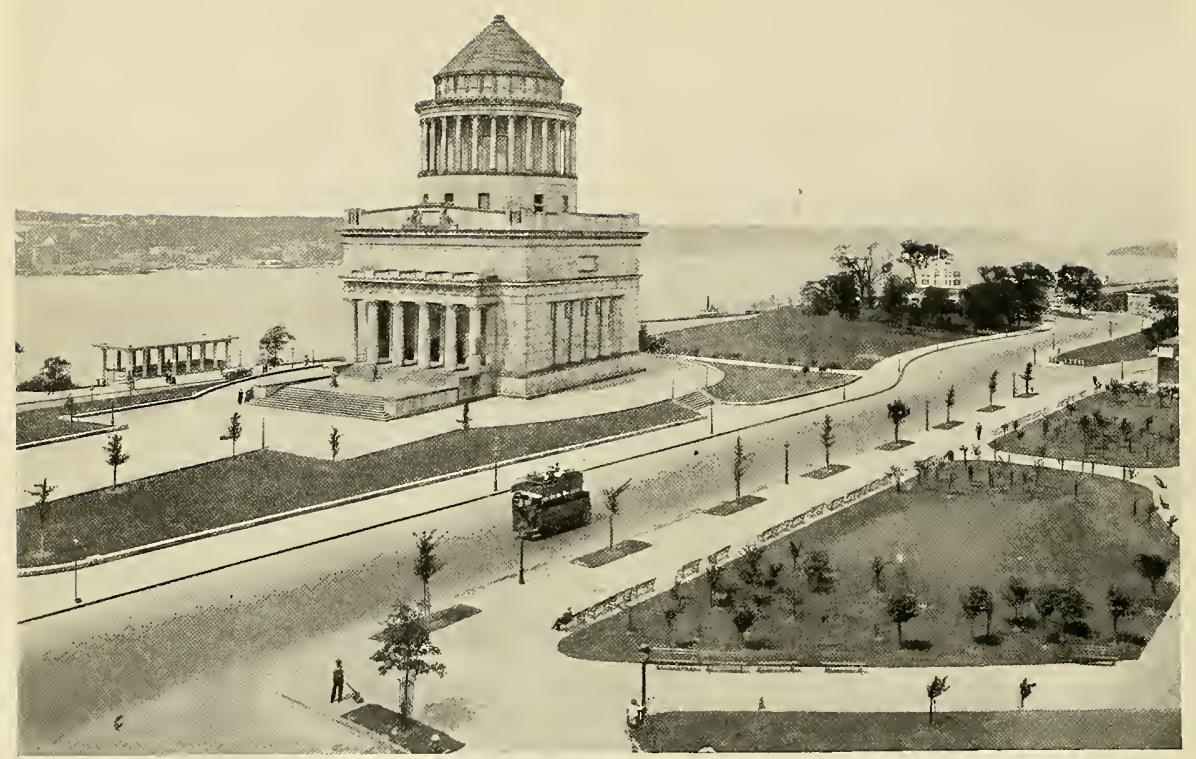

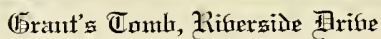

The Tomb of General Grant in Riverside Drive, I2 Ist Street and Hudson River. Erected by popular subscription.

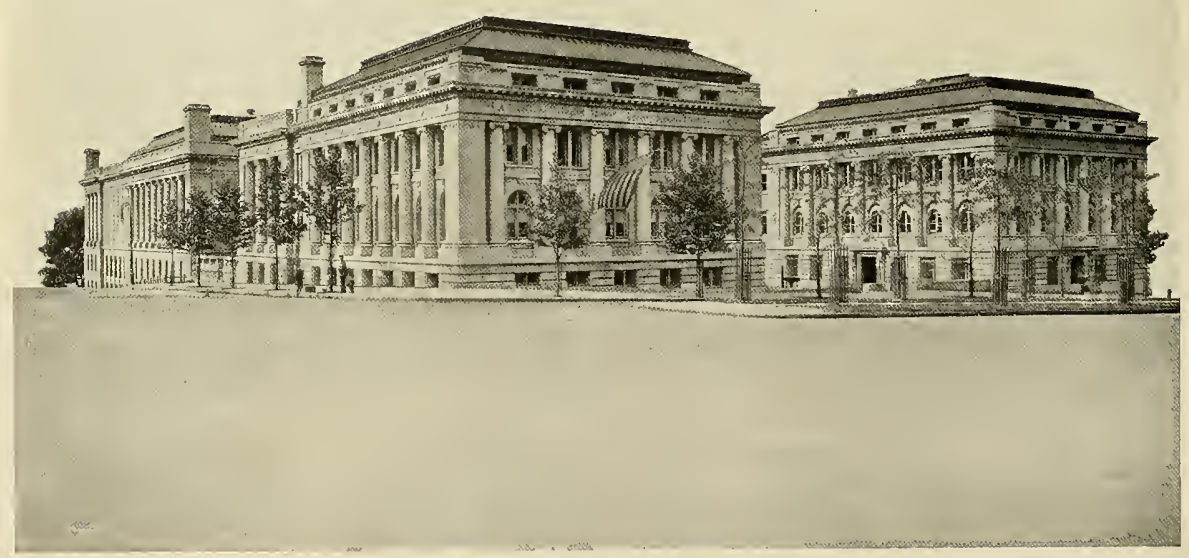

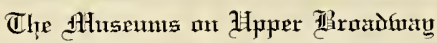

In the Quadrangle on Broadway between 155 th and 156 th Streets and Riverside Drive is the famous Museum of the Hispanic Society, the American Geographical Society, the Numismatic Society, the American Indian Museum, Heye Foundation and the American Academy of Arts and Letters. This view shows the Broadway frontage. 


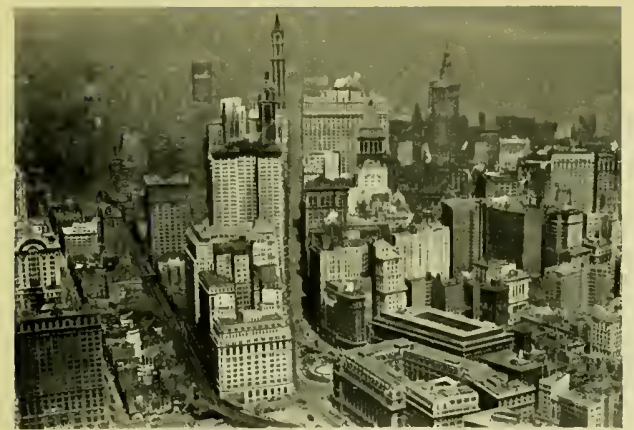

Up Broadway from the Battery.

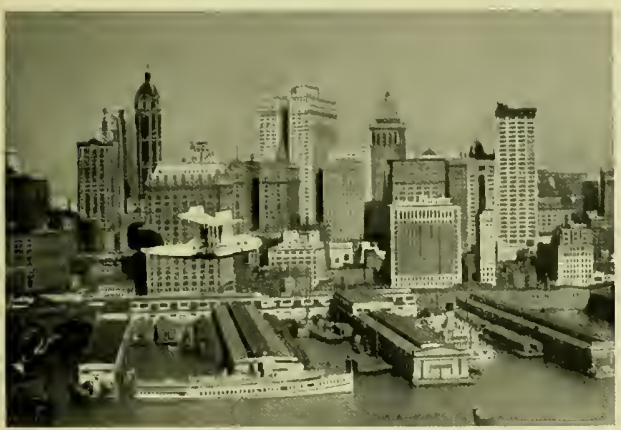

The Financial Section from the Hudson.

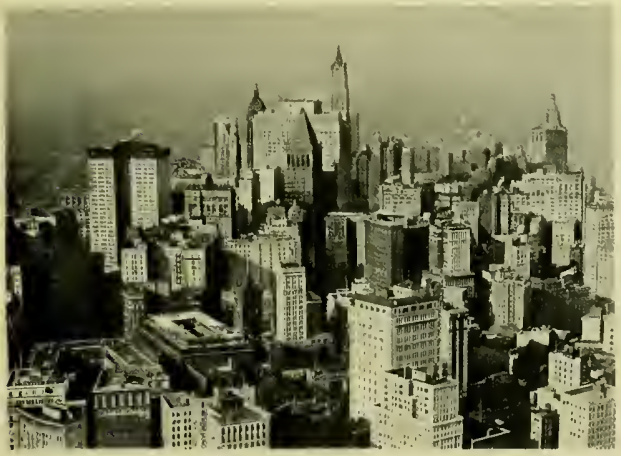

Looking North.

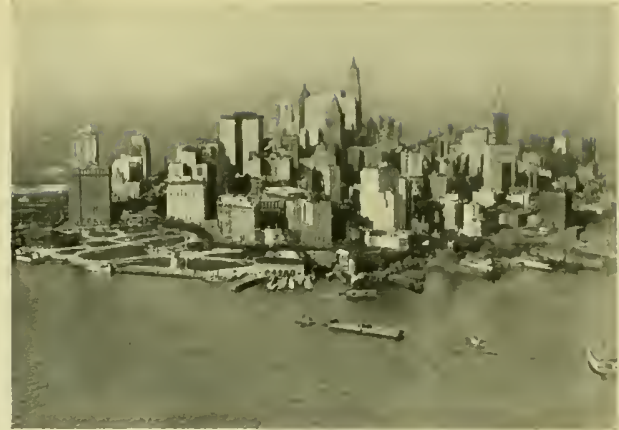

The Find of the Island.

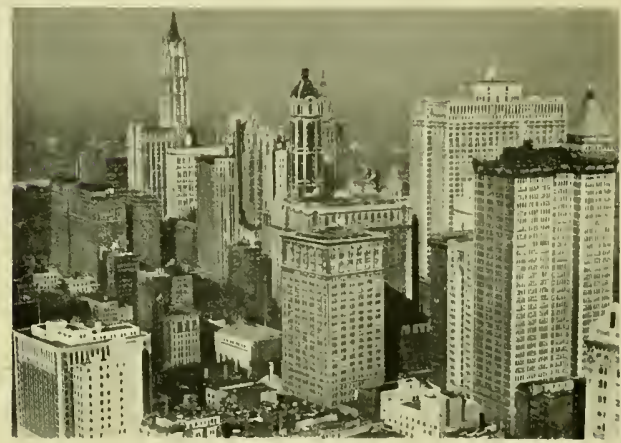

The Woolworth, Singer and Equitable Skyscrapers.

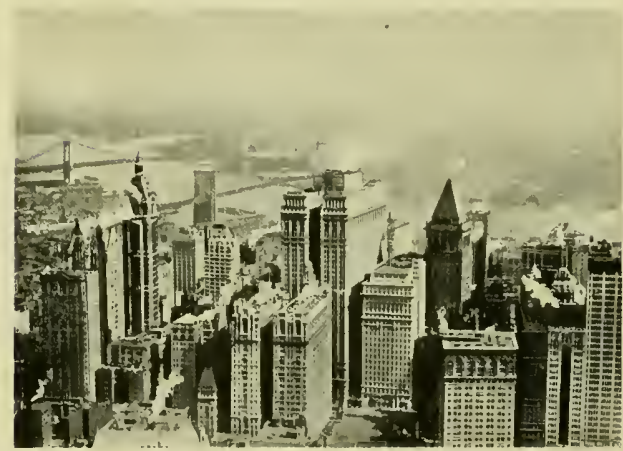

A Glimpse of the East River.

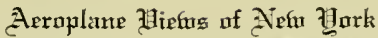

Some Aeroplane views in the canyon section of down town New York taken by Major Maxwell. In the second view from the top on the left is shown the Passenger Flyer used to show visitors over the City or to make special trips to nearby resorts. 


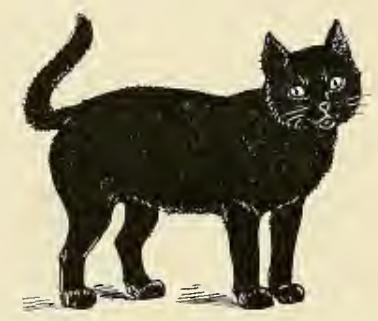

Do You Remember Barnum's Cherry-colored Cat?

Of Course You Do It Was Black 







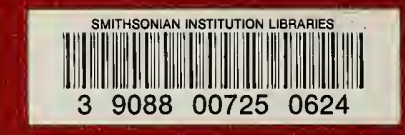

